EDITORA

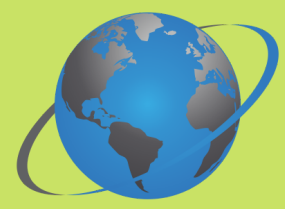

OMNIS SCIENTIA

\title{
ANAIS DO
}

II Congresso Narte-Nordeste de Educação Inchusiva e Suas Tecrolagias.

(ONLINE)
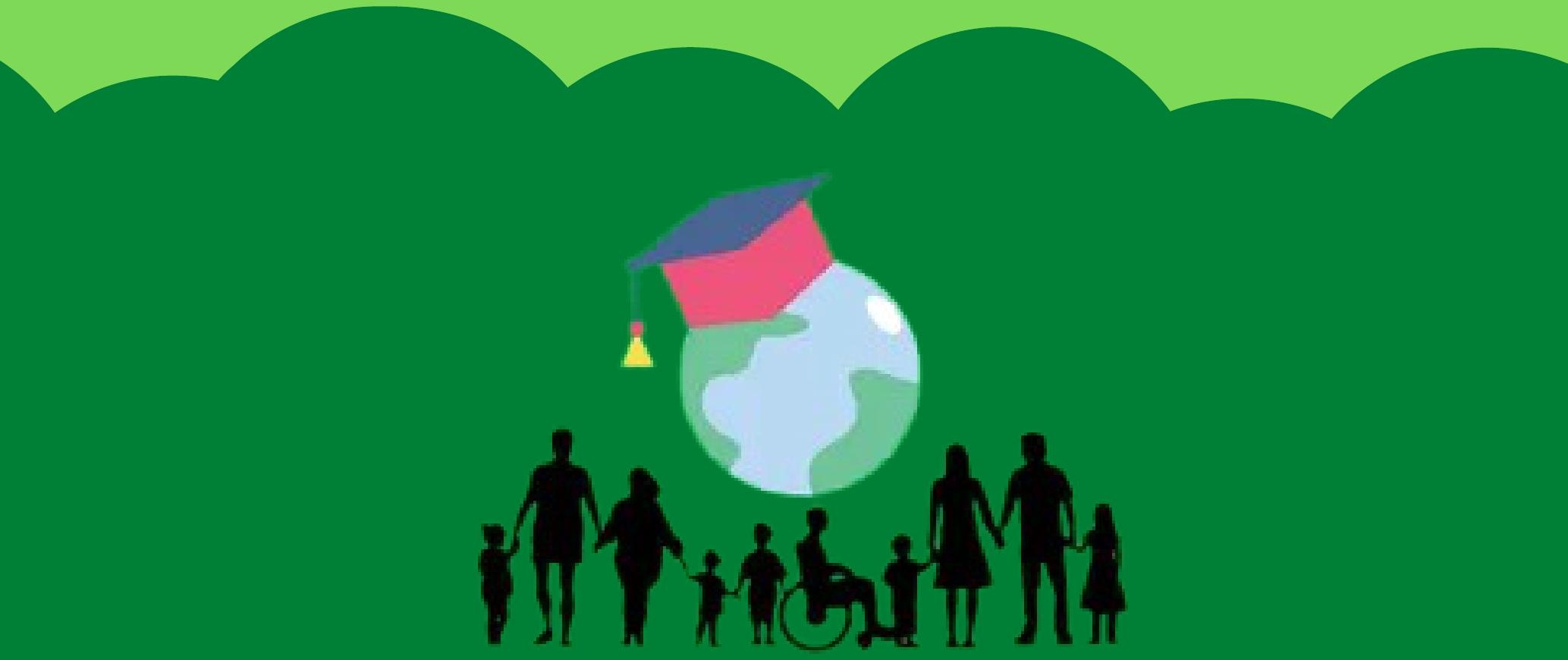

II CONGRESSO NORTE- NORDESTE DE EDUCAÇ̄̃

INCLUSIVA E SUAS TECNOLOGIAS [ONLINE] 
EDITORA

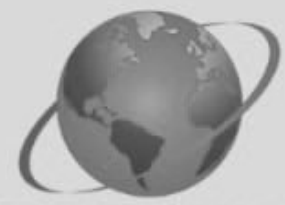

OMNIS SCIENTIA

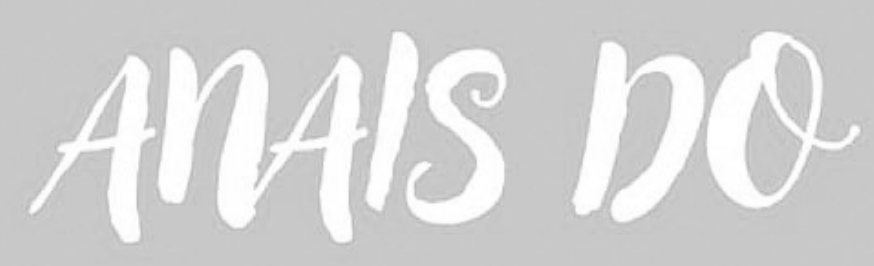

II Congresso Norte-Noradeste de Educachão Inchusiva e Suas Tecnolagias. (ONLINE)
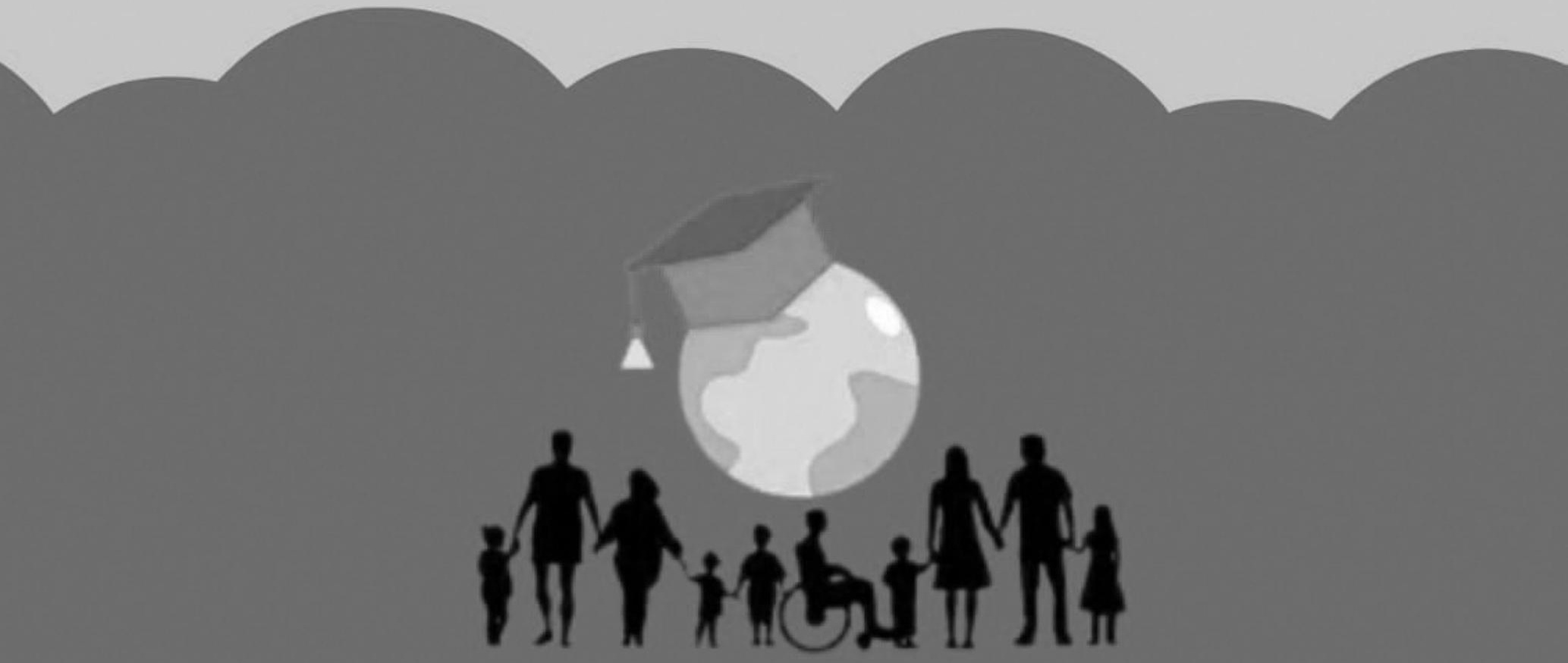

॥ CONGRESSO NORTE- NORDESTE OE EDUCACĀO

INCLUSIVA E SUAS TECNOLOGIAS [ONLINE] 
Editora Omnis Scientia

\begin{abstract}
ANAIS DO
II CONGRESSO NORTE-NORDESTE DE EDUCAÇÃO INCLUSIVA E SUAS TECNOLOGIAS

(ONLINE)
\end{abstract}

Volume 1

$1^{\mathrm{a}}$ Edição

TRIUNFO - PE 


\section{COORDENADOR CIENTÍFICO}

Eder Ferreira de Arruda

\section{COORDENADOR DE PUBLICAÇÃO}

Daniel Luís Viana Cruz

\section{COORDENADORA DO EVENTO}

Andréa Telino Gomes

\section{ORGANIZADORES}

Academics - Eventos acadêmicos online

Editora Omnis Scientia

Andréa Telino Gomes

Daniel Luís Viana Cruz

Eder Ferreira de Arruda

Liverson dos Santos Teixeira Felix de Paiva

\section{PALESTRANTES}

Aline Martins de Almeida

Claudia Coelho Hardagh

Fernando Luis Cazarotto Berlezzi

Jovanka M. de Genova Ferreira

Keynayanna Késsia Costa Fortaleza

Luiz Alfredo de Paula

Marcelo Luiz Bezerra da Silva

Maria Aparecida Ferreira de Paiva

Pollyanna Souza

Sheila Cristina Silva Aragão Caetano

Talita Araújo Salgado Alvarez Faustino

\section{AVALIADORES}

Ana Paula Freitas da Silva

Edilza Laray de Jesus

Gabriela Dutra Rodrigues Conrado

José Miranda Oliveira Júnior

Larissa Silva Alves

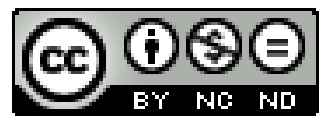

Este trabalho está licenciado com uma Licença Creative Commons - AtribuiçãoNãoComercial-SemDerivações 4.0 Internacional.

O conteúdo abordado nos artigos, seus dados em sua forma, correção e confiabilidade são de responsabilidade exclusiva dos autores. 


\section{Dados Internacionais de Catalogação na Publicação (CIP)}

(eDOC BRASIL, Belo Horizonte/MG)

Congresso Norte-Nordeste de Educação Inclusiva e suas Tecnologias $(2: 2021)$

C749a Anais do [...] / II Congresso Norte-Nordeste de Educação Inclusiva e suas Tecnologias, 26 setembro 2021; coordenador Daniel Luís Viana Cruz. - Triunfo, PE: Omnis Scientia, 2021. $118 \mathrm{p}$.

Formato: PDF

Requisitos de sistema: Adobe Acrobat Reader

Modo de acesso: World Wide Web

ISBN 978-65-88958-76-6

DOI 10.47094/978-65-88958-76-6

1. Educação inclusiva - Brasil - Congressos. 2. Prática de ensino. 3. Professores - Formação. I. Cruz, Daniel Luís Viana. II.Título.

CDD 371.72

Elaborado por Maurício Amormino Júnior - CRB6/2422

Editora Omnis Scientia

Triunfo - Pernambuco - Brasil

Telefone: +55 (87) 99656-3565

$\underline{\text { editoraomnisscientia.com.br }}$

contato@editoraomnisscientia.com.br 


\section{EDITORIAL}

Em tempos tão difíceis como os que encaramos, uma temática que já é extremamente complexa, ganha ainda mais importância. A Educação Inclusiva, área da educação que está em pleno crescimento, em virtude da demanda social, graças às leis que regulamentam e garantem às pessoas que necessitam de acesso adequado, exercer seu pleno direito de cidadão. Muitas vezes, as técnicas e metodologias utilizadas, requerem ferramentas tecnológicas e equipamentos especiais para melhorar a eficiência do aprendizado do público que utiliza dos serviços educacionais, seja como profissional da área, seja como aluno.

O II Congresso Norte Nordeste de Educação Inclusiva e Suas Tecnologias (online), II CONEIST, criou uma troca de experiência e atualização do conhecimento. Teve como objetivo atualizar e informar aos participantes sobre os temas relacionados. O público alvo foram os estudantes de graduação, de pós-graduação e profissionais da área de ensino.

O II CONEIST ocorreu no dia 26 de setembro de 2021 e contou com palestras, submissões de trabalhos nas modalidades de resumo simples e expandido, onde os aprovados foram expostos na plataforma do evento. Os participantes receberam certificados de 20 horas.

Os três melhores resumos em cada modalidade receberam certificados de menção honrosa.

Conheçam os títulos dos resumos que foram premiados por ordem de submissão:

\section{Modalidade Resumo Expandido}

406529 - EDUCAÇÃO E PANDEMIA: O ATENDIMENTO EDUCACIONAL ESPECIALIZADO NUMA ESCOLA MUNICIPAL DA ZONA RURAL

410614 - O TRABALHO DO NEUROPSICOPEDAGOGO NO ATENDIMENTO DE CRIANÇAS COM TEA

412383 - TRIAGEM AUDITIVA ESCOLAR: UMA REVISÃO DE LITERATURA

\section{Modalidade Resumo Simples}

389954 - ESTÁGIO SUPERVISIONADO E A INCLUSÃO NAS AULAS DE EDUCAÇÃO FÍSICA NOS ANOS FINAIS DO ENSINO FUNDAMENTAL

411413 - APRENDIZAGEM DE ALUNOS COM DEFICIÊNCIA INTELECTUAL COM USO DE JOGOS: UMA AÇÃO DE SENSIBILIZAÇÃO AMBIENTAL SOBRE OS RECURSOS HÍDRICOS 412651 - A EDUCAÇÃO INCLUSIVA NO ENSINO SUPERIOR TEM CONTEMPLADO ESTUDANTES COM TRANSTORNO DO ESPECTRO AUTISTA?

Agradecemos a todos os participantes, palestrantes, avaliadores e organizadores do II CONEIST pela participação e colaboração no congresso. 


\section{SUMÁRIO \\ RESUMO SIMPLES}

\section{EDUCAÇÃO DE SURDOS E SUAS TECNOLOGIAS}

A IMPORTÂNCIA DA LIBRAS NO PROCESSO DE ENSINO APRENDIZAGEM DO

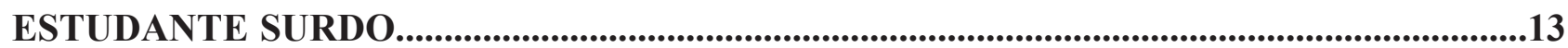

\section{EDUCAÇÃO E INCLUSÃO DIGITAL}

LETRAMENTO MIDIÁTICO E A MANIPULAÇÃO DO DISCURSO JORNALÍSTICO NO GÊNERO NOTÍCIA

\section{EDUCAÇÃO ESPECIAL}

EXPERIÊNCIAS NO PIBID: UMA APRENDIZAGEM SIGNIFICATIVA .17

DESAFIOS ENCONTRADOS NA ALFABETIZAÇÃO DE ALUNOS COM DEFICIENCIA INTELECTUAL

EDUCAÇÃO ESPECIAL EM TEMPOS DE PANDEMIA: QUEBRANDO PARADIGMAS..

EDUCAÇÃO ESPECIAL: EXPERIÊNCIAS VIVENCIADAS NO PIBID ATRAVÉS DO ENSINO REMOTO. .20

PROFISSIONAIS COM DEFICIÊNCIA FÍSICA E/OU NECESSIDADES ESPECIAIS NO AMBIENTE EDUCACIONAL DO MUNICÍPIO DE TIMBIRAS-MA......................21

INCLUSÃO X EXCLUSÃO: ENSINO REMOTO PARA ALUNOS DO ATENDIMENTO EDUCACIONAL ESPECIALIZADO. 
ADOLESCENTES, JOVENS E ADULTOS: A DIVERSIDADE QUE TRANSVERSALIZAR O APRENDER E O ENSINAR. . .24

A INCLUSÃo ESCOLAR É POSSÍVEL DE SER EFETIVAdA NA ESCOLA REGULAR? .25

IMPASSES DA CONCRETIZAÇÃO DAS LEGISLAÇÕES ESPECÍFICAS VOLTADAS À INCLUSÃO DAS PESSOAS COM DEFICIÊNCIA NO CONTEXTO ESCOLAR.........26

\section{INCLUSÃO NA EDUCAÇÃO PROFISSIONALIZANTE}

A EMPATIA COMO SABER EM INCLUSÃO ESCOLAR PARA FORMAÇÃO CONTINUADA DOS PROFISSIONAIS DA EDUCAÇÃO ESPECIAL NOS IFS. .28

RELATO DE EXPERIÊNCIA SOBRE APLICAÇÃo DE PROJETO DE SINALIZAÇÃo PARA PESSOAS CEGAS E SURDAS NO IFBA CAMPUS JACOBINA.

INCLUSÃO NO ENSINO DAS CIÊNCIAS (MATEMÁTICA, FÍSICA, QUÍMICA E BIOLOGIA)

APRENDiZAGEM de ALUNOS COM DEFICIÊNCIA INTELECTUAL COM USO DE JOGOS: UMA AÇÃO DE SENSIBILIZAÇÃO AMBIENTAL SOBRE OS RECURSOS HÍDRICOS. . .31

\section{OUTRAS ÁREAS AFINS}

ESTÁGIO SUPERVISIONADO E A INCLUSÃo NAS AULAS DE EDUCAÇÃO FÍSICA NOS ANOS FINAIS DO ENSINO FUNDAMENTAL........................................33 
A EDUCAÇÃO INCLUSIVA NO ENSINO SUPERIOR TEM CONTEMPLADO ESTUDANTES COM TRANSTORNO DO ESPECTRO AUTISTA?.................................35

POLÍTICAS EDUCACIONAIS: GESTÃO ESCOLAR, FORMAÇÃO DOCENTE E INCLUSÃO

PLANEJAMENTO DE POLÍTICAS EDUCACIONAIS NA LÓgICA DA INCLUSÃo: A META 4 DO PLANO NACIONAL DE EDUCAÇÃo (2015-2025)....................................37

A IMPORTÂNCIA DA FORMAÇÃo PROFISSIONAL NO ENSINO DE GEOGRAFIA PARA INCLUSÃo DE PESSOAS COM DEFICIÊNCIA: UMA ANÁlISE CURRICULAR DOS CURSOS DE GRADUAÇÃO EM LICENCIATURA...........................38

A IMPORTÂNCIA DO PAPEL DO PROFESSOR EM TEMPOS DE PANDEMIA:

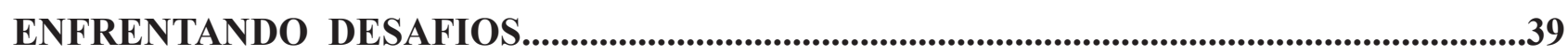




\section{SUMÁRIO \\ RESUMO EXPANDIDO}

\section{EDUCAÇÃO ESPECIAL}

EDUCAÇÃO E PANDEMIA: O ATENDIMENTO EDUCACIONAL ESPECIALIZADO NUMA ESCOLA MUNICIPAL DA ZONA RURAL

O USO DE TECNOLOgIAS EDUCACIONAIS QUE AUXILIAM O PROFESSOR NO PROCESSO DE ALFABETIZAÇÃO DE ALUNOS COM DISLEXIA. 45

AUTISMO EM TEMPOS DE PANDEMIA: COMO ESTÁ SENDO SUA INCLUSÃO NO ÂMBITO ESCOLAR?

ESPAÇO ESCOLAR E INCLUSÃO: DiÁlOGOS E REFLEX̃̃ES, UM ESTUDO DE CASO. .53

ATENDIMENTO EDUCACIONAL ESPECIALIZADO PARA ALUNOS COM DEFICIÊNCIA AUDITIVA NO ÂMBITO DO ENSINO REMOTO..................................56

O TRABALHO DO NEUROPSICOPEDAGOGO NO ATENDIMENTO DE CRIANÇAS COM TEA.

INCLUSÃO EDUCACIONAL, DIFICULDADES DE APRENDIZAGEM E POLÍTICAS PÚBLICAS

PERSPECTIVAS HISTÓRICAS DA EDUCAÇÃo PARA PESSOAS COM DEFICIÊNCIA E SURDEZ NA BAHIA. .65

TRIAGEM AUDITIVA ESCOLAR: UMA REVISÃO DE LITERATURA 69

TRILHANDO AINCLUSÃO NOAMBIENTE ESCOLAR: COMUNICAÇÃO ALTERNATIVA NA APRENDIZAGEM DE LÍNGUA INGLESA NO ENSINO FUNDAMENTAL .73 
DESENHO UNIVERSAL DA APRENDIZAGEM PARA O ENSINO DO TEOREMA DE PITÁGORAS.

PROPOSTA DE AULA PRÁTICA ADAPTADA PARA O ENSINO DE CIÊNCIAS PARA ALUNOS COM TRANSTORNO DO ESPECTRO AUTISTA .83

MATERIAL DIDÁTICO ADAPTADO PARA O ENSINO DE CIÊNCIAS: ESTRATÉGIAS PARA ALUNOS COM DEFICIÊNCIA VISUAL NO CONTEXTO DO ENSINO REMOTO. .87

\section{OUTRAS ÁREAS AFINS}

EDUCAÇÃO ESPECIAL NA PERSPECTIVA DA INCLUSÃO ENTRE O DITO E O PRATICADO. . .92

GESTÃO DO NÚCLEO DE PESQUISA E EXTENSÃO EM DESTAQUE: ÉTICA, DIVERSIDADE E INCLUSÃO - UM RELATO DE EXPERIÊNCIA. .96

\section{POLÍTICAS EDUCACIONAIS: GESTÃO ESCOLAR, FORMAÇÃO DOCENTE E INCLUSÃO}

GEOTECNOLOGIAS COMO SUBSÍDIO PARA A INCLUSÃO DE PESSOAS COM DEFICIÊNCIA NO AMBIENTE ESCOLAR EM RIO BRANCO, ACRE. .101

A GÊNESIS DA FORMAÇÃO DE AGENTES PARA UMA EDUCAÇÃO EX/ INCLUSIVA: O INÍCIO JUSTIFICANDO O FIM. .106 


\section{RESUMO SIMPLES}

EDUCAÇÃO DE SURDOS E SUAS TECNOLOGIAS 


\section{A IMPORTÂNCIA DA LIBRAS NO PROCESSO DE ENSINO APRENDIZAGEM DO ESTUDANTE SURDO}

Ivanilton Ferreira; Fabricia Ferreira; Árllon Chaves Lima; Alcione Batista Da Silva.

O presente trabalho aborda a seguinte temática: A Importância da Libras no Processo de Ensino Aprendizagem do Estudante Surdo. Como introdução à temática, partimos da ideia de que a sociedade está em constante transformação, por isso, apresentamos a premissa que a educação transforma a vida das pessoas, e os indivíduos surdos fazem parte dessa sociedade e estão presentes nas escolas regulares. Sendo assim, faz-se relevante fomentar o debate acerca da importância da Libras no processo de ensino aprendizagem desses estudantes. Desta forma, o objetivo deste trabalho é identificar as dificuldades do professor ouvinte, da sala de aula regular, no trabalho com a Libras em prol do educando surdo, a fim de promover uma reflexão no que tange o processo de ensino e de aprendizagem, a comunicação e a construção de conhecimentos dos surdos numa perspectiva bilíngue: Língua de Sinais-L1 e Língua Portuguesa-L2. A metodologia empregada constituiu-se em uma pesquisa bibliográfica observando os desafios colocados pela Política Nacional de Educação Especial na Perspectiva da Educação Inclusiva (2008), que tem como objetivo fundamental a educação inclusiva de acolher todas as diferenças em ambientes que propiciem uma educação de qualidade para todos. De acordo com a Constituição Federal em seus artigos 205 e 208, inciso III, diz que o "atendimento educacional especializado aos portadores de deficiência, preferencialmente na rede regular de ensino". Após pesquisas e leituras realizadas sobre a educação de surdos, concluímos o quanto é fundamental e importante a efetivação de políticas públicas, a fim de reparar e corrigir exclusões vivenciadas pelos surdos ao longo da história.

Palavras-Chave: Inclusão de Surdos. Língua de Sinais. Escola Regular.

Área temática: Educação de Surdos e suas tecnologias. 


\section{RESUMO SIMPLES}

EDUCAÇÃO E INCLUSÃO DIGITAL 


\section{LETRAMENTO MIDIÁTICO E A MANIPULAÇÃO DO DISCURSO JORNALÍSTICO NO GÊNERO NOTÍCIA}

Marcos Daniel Carvalho Teixeira; Maria Cristina Morais de Carvalho.

Este trabalho apresenta uma análise da manipulação do discurso jornalístico através do gênero textual notícia, na perspectiva do letramento midiático, propondo despertar o senso crítico dos alunos, através das práticas de leitura e reescritas ao usa-los o gênero. $\mathrm{O}$ ensino com texto jornalístico tem como relevância social, resgatar os conhecimentos que permeiam no universo da educação midiática, permitindo aos alunos reconectarem com diversos saberes, entre eles, as manipulações tendenciosas da mídia, tornando-os assim competentes nos vocabulários de comunicação e informações discursiva e linguística do letramento midiático. Deste modo, fundamentamos essa pesquisa no conceito de letramento como prática social (STREET 1984, 2014; BARTON 1994; SOARES 2003; ROJO 2002; KLEIMAN 1995), no letramento midiático (GONNET 2004; MOCELLIN 2009; FANTIN 2012; SETTON 2021 e FREIRE_et_al_2020), nas informações presentes nas notícias que são manipuladas a fim de estabelecer um abuso de poder (VAN DIJK 1988, 2000, 2005,2006, 2010, 2015), e no gênero do discurso (Bakhtin 2003, Marcuschi 2010). Diante desses pressupostos, desenvolvemos uma sequência didática no formato de oficina aos estudantes do Ensino Médio Técnico Integrado do Instituto Federal de Goiás campus Goiânia, a fim de ampliar suas práticas de letramento midiático e como também a percepção ao visualizar manipulações, sabendo identificá-las as informações implícitas e explícitas na notícia. Usando a metodologia de cunho qualitativo, a pesquisa-ação (TRIP, 2005) é a modalidade metodológica de apoio mais adequada para o desenvolvimento das sequências didáticas (DOLZ et al., 2004) no formato de oficinas de leitura e reprodução de notícias. Assim, a sequência didática gerarão os dados de análise, os quais serão divididos nos seguintes momentos: atividade inicial de leitura e reescrita de notícia, atividades de leitura, produção textual final. Por fim, analisaremos os resultados a partir das inferências sugeridas (TRAUGOTT \& DASHER, 2005), mostrando a importância e a complexidade de trabalhar a manipulação do discurso jornalístico no ensino de língua portuguesa.

Palavras-Chave: Letramento Midiático. Manipulação. Gênero Notícia.

Área temática: Educação e Inclusão Digital. 
RESUMO SIMPLES

EDUCAÇÃO ESPECIAL 


\title{
EXPERIÊNCIAS NO PIBID: UMA APRENDIZAGEM SIGNIFICATIVA
}

\author{
Aziel Alves de Arruda; Denise da Silva Santos; \\ Jardson Vinicios Galvão dos Santos; Juliana Moreira Nogueira; \\ Francisca dos Santos Salazar; Francisco das Chagas do Nascimento Lago; \\ Lizauria Dos Aflitos Medeiros; Maria Patrícia Do Vale De Sousa; \\ Krysman Félix da Silva.
}

O programa Institucional de Bolsa de Iniciação à Docência - PIBID promove uma relação entre a universidade e escolas, com objetivos a serem trabalhados na educação. No campus de Codó, o projeto tem como foco, a Educação especial. O projeto teve início ano de 2020, com o intuito de auxiliar os alunos com necessidades especial no processo de alfabetização, para nós bolsista está sendo uma experiência de extrema importância pois, além de aperfeiçoar nossos currículos, percebemos que educação especial dentro das escolas ainda é um desafio a ser enfrentado. Objetivo: Inserir o licenciando no cotidiano escolar voltado para Educação Inclusiva e Especial; Contribuir para a articulação da teoria e prática necessárias para uma Alfabetização significativa. Metodologia: ao longo desse processo tivemos o privilégio de compreender como se dava esse aprendizado e quais caminhos podem ser percorridos a fim de ajudar essas crianças, poder fazer parte do processo de alfabetização dessas crianças e ajuda-las a desenvolverem suas habilidades respeitando suas limitações. Quando nos foi passado sobre o foco do nosso projeto, ficamos bem entusiasmados e curiosos, porque sabemos o quão é importante esse tema, onde o mems é de suma importância para nossa formação, uma vez que vamos trabalhar com crianças especiais. Um dos maiores desafios para os participantes do projeto, é não poder estar junto às crianças por conta da pandemia da Covid-19 e ter que fazer tudo remotamente, no entanto estamos conseguindo bons resultados. Resultados: Já fizemos um curso de especialização em educação inclusiva online, e tivemos que apresentar um seminário com um assunto que mais nos interessava, tivemos palestras com especialistas da área, fomos orientados a fazer jogos pedagógicos adaptados para cada criança das escolas participante, infelizmente não podemos fazer a entrega como gostaríamos e ver a reação das mesmas, mas conseguimos fazer com que chegassem até as crianças. Conclusão: Durante esse tempo do projeto, percebemos o quanto as crianças com necessidades especiais ainda sofrem para conseguir uma educação de qualidade, as dificuldades vão desde as estruturas das escolas até a má formação dos professores, e nós como futuros educadores, temos que mudar essa realidade, mas que é preciso termos políticas públicas que venham dar resultados positivos para esta realidade.

Palavras-Chave: Educação Especial. Experiências. Alfabetização Significativa.

Área temática: Educação Especial. 
Aziel Alves de Arruda; Francisco das Chagas do Nascimento Lago;

Lizauria dos Aflitos Medeiros; Maria Patrícia do Vale De Sousa;

Krysman Félix da Silva; Juliana Moreira Nogueira;

Jardson Vinicios Galvão dos Santos; Denise da Silva Santos;

Maria do Amparo dos Anjos.

Crianças com deficiência intelectual (DI), sofrem constantemente com o processo de alfabetização nas Instituições Escolares, no entanto, este trabalho apresenta uma pesquisa de carácter qualitativo, no qual, aborda os desafios encontrados na alfabetização de alunos com deficiência intelectual (DI). Almejando estabelecer um diálogo entre o leitor e a realidade da Unidade Escolar Municipal São Luis, observando suas limitações, buscando assim, refletir sobre possibilidades de efetivação do processo de inclusão, mediante as dificuldades encontradas. Ou seja, a realização de questionários utilizando as ferramentas "Word" e "Google Forms", contribuíram para que os objetivos fossem alcançados plenamente, possibilitando perceber no quanto há limitações em relação a equidade e inclusão de crianças deficientes, no processo ensino-aprendizagem nessa instituição, pois a mesma não possui ambientes adequados e recursos para o combate das problemáticas presentes. Dessa forma, sobrecarregando os professores, pois mesmo que tenham como foco a inclusão, não conseguem agir sozinhos em prol da mesma, devido à falta de formação específica, para lidar com essa realidade. Portanto, conclui-se que é de suma importância ter um sistema de ensino adequado para receber os alunos com necessidades especiais. E, professores capacitados, dando suporte adequado, para que possam atender essas crianças em suas especificidades, onde os alunos possam ser capazes de aprender dentro das suas limitações, assim, desenvolvendo habilidades e autonomia sobre suas vidas.

Palavras-Chave: Deficiência intelectual. Professores. Inclusão.

Área temática: Educação Especial. 


\title{
EDUCAÇÃO ESPECIAL EM TEMPOS DE PANDEMIA: QUEBRANDO PARADIGMAS
}

\author{
Aziel Alves De Arruda; Joane Beatriz Santos Meneses; Luciana Rodrigues Da Silva; \\ Rita De Cássia Jaco Mota; Adriene De Oliveira Da Silva; Elenilde Câmara De Lima; \\ Maria Das Neves Alves Ramos; Sara De Carvalho Gomes; Sarah Luz Da Conceição; \\ Nadia Alynne Da Silva Carneiro.
}

$\mathrm{Na}$ atualidade a sociedade vive um grande desafio em efeito do surgimento da COVID-19, pois com a pandemia escolas tiveram que suspender as aulas presencias, e outras instituições escolares tiveram que fechar suas portas contemplando grandes problemas no processo educacional dos alunos, principalmente para os alunos com necessidades especiais que antes apresentavam grandes avanços em relação autonomia e autoconfiança, porém, em detrimento de estarem afastados das escolas e das salas de aulas por causa do distanciamento social retrocederam, antes da pandemia os educandos com necessidades especiais tinham acompanhamento de profissionais capacitados para the dar com as especificidade de cada sujeito reconhecendo os limites de cada aluno, mas agora quem estar na frente desse processo são seus responsáveis que em muitos casos não tem um conhecimento pedagógico para esta auxiliando os mesmos. Objetivo: $O$ trabalho visa compreender como a educação inclusiva e educação especial para alunos com necessidades especiais estão acontecendo, tendo em vista os grandes desafios causados pela pandemia da Covid-19. Metodologia: O trabalho foi desenvolvido através de pesquisas bibliográficas buscando reunir e analisar através de obras publicadas sobre o contexto da educação inclusiva e educação especial. Resultados: no entanto, compreende-se que as escolas e os professores precisaram ir em busca de novos métodos para que a educação não parasse, fazendo repensar suas práticas, planejamentos, metodologias e recursos que ajudassem no processo de inclusão desses alunos com necessidade especiais. ou seja, foram surgindo novas possibilidade para que a educação fosse garantida, oferecendo uma educação de qualidade para esses alunos, é constatado que a educação inclusiva e educação especial tem encontrado no ambiente escolar diversos desafios no sua dia a dia , uma vez que para que ocorra o processo significativo de inclusão desses alunos se faz necessário diversas políticas públicas educacionais voltadas para pessoas com necessidades especiais e que auxiliem no processo de ensino aprendizagem visando uma educação de qualidade para todos, uma vez que a realização das aulas estão acontecendo de forma remota, esse cenário de acesso as tecnologias não são para todos, as tecnologias têm se tornado um grande vilão colocando barreiras e agravando no processo de desigualdade, já que nem todas as pessoas têm acesso a celulares, computadores, notebook, tablet e muitos menos tem uma rede de internet em casa. Portando, para que ocorra a inclusão do aluno com necessidades especiais as escolas devem oferecer recursos que contemplem a todos, buscando uma processo ensino aprendizagem significativos.

Palavras-Chave: Pandemia. Políticas públicas. Alunos com Necessidades Especiais.

Área temática: Educação Especial. 
Aziel Alves de Arruda; Adriene de Oliveira da Silva;

Elenilde Câmara de Lima; Maria das Neves Alves Ramos;

Sara de Carvalho Gomes; Sarah Luz da Conceição;

Joane Beatriz Santos Meneses; Luciana Rodrigues da Silva;

Rita de Cássia Jaco Mota; Nadia Alynne da Silva Carneiro.

A educação especial é uma modalidade educacional, onde as práticas de ensino devem está sempre condizentes a deficiência do aluno para que ele alcance o aprendizado e esteja incluso em diferentes ambientes, sobretudo, no escolar agindo e interagindo com os demais. Nesse período de pandemia causado pelo Coronavírus, toda comunidade escolar teve de se adaptar e reinventar ao ensino remoto. Por um lado, o ensino remoto corroborou para uma melhor formação de muitos educadores os quais adquiriram grandes habilidades por meio das tecnologias. Por outro viés, têm sido evidentes os grandes impactos causados na aprendizagem de milhares de alunos. A educação especial já integra uma grande carência na formação de professores, com a pandemia da Covid-19 essa situação ficou ainda mais critica, além do problema da ausência de professores especializados, surgiu também a falta de acesso a internet e assim como manejo das ferramentas tecnológicas, tornando assim um grande desafio para todos os alunos. Tendo como ponto de partida esse contexto, este trabalho caracterizase como um relato de experiência vivenciado no Programa Institucional de Bolsas de Iniciação a Docência (PIBID). O programa objetiva possibilitar a interação entre o ensino superior a educação básica. O trabalho apresentado desenvolveu-se mediante o subprojeto "sentidos e significados da Alfabetização voltados para os alunos com necessidades especiais" o qual é realizado por bolsistas na escola Rosangela Moura em Codó-MA. O principal objetivo desse trabalho é relatar experiências do PIBID na educação especial através do ensino remoto. Ainda em andamento, o projeto teve inicio em novembro de 2020, a princípio, com a formação através de cursos da área da educação especial para que os alunos pudessem conhecer mais sobre as diferentes deficiências, houve apresentações, e também a confecção de jogos pedagógicos, feitos pelos bolsistas de acordo com a deficiência de cada aluno. Durante as formações no PIBID, percebeu-se que, ainda existem muitas barreiras a serem derrubadas na educação especial. Logo, as experiências enquanto bolsistas são imprescindíveis para a atuação enquanto futuro profissional.

Palavras-Chave: Formação. Professores. Escola.

Área temática: Educação Especial. 


\title{
PROFISSIONAIS COM DEFICIÊNCIA FÍSICA E/OU NECESSIDADES ESPECIAIS NO AMBIENTE EDUCACIONAL DO MUNICÍPIO DE TIMBIRAS-MA
}

\author{
Aziel Alves de Arruda; Bianca Carneiro da Silva;
}

Andressa de Brito Silva; Maria Hyannes Silva de Souza.

A inclusão da pessoa com deficiência física no contexto social ainda gera longos debates no que diz respeito à acessibilidade de espaços aos quais foi conquistado o direito de estar e permanecer, e no que se refere ao ambiente de trabalho não é diferente. Apesar de existirem várias leis e decretos aprovados que asseguram o direto da pessoa com deficiência física o acesso à educação e ao trabalho, esses direitos nem sempre são respeitados, seja por falta de preparo estrutural e social do ambiente para receber o (a) profissional com necessidades especiais. A presente pesquisa teve como objetivo investigar a presença de professores com deficiência física e/ou necessidades especiais nas escolas do município de Timbiras-MA e analisar as dificuldades encontradas no contexto escolar por estes professores. Primeiramente, realizamos o levantamento bibliográfico considerando os trabalhos essenciais que respaldam a pesquisa. Adiante, mediante a entrevista e questionário aplicado através da ferramenta digital Whatsapp, foi realizada a pesquisa de campo em que foram consideradas a Secretaria de Educação e as escolas do Ensino Fundamental da rede pública de ensino do município de Timbiras, Maranhão. Apesar de não ter professores com deficiência e/ou necessidades especiais efetivos nas escolas do município de Timbiras-MA, identificamos a presença de dois supervisores que se enquadram na pesquisa. Entretanto, a partir da análise dos dados coletados, nota-se que nem todas as escolas dos municípios se encontram aptas estruturalmente para receber tanto alunos como profissionais em seu espaço, devido à falta de acessibilidade destes ambientes. A inclusão/integração plena de pessoas com deficiência física e/ou necessidades especiais no espaço regular de ensino ainda encontra vários empecilhos e resultam em lentas mudanças, que na maioria das vezes ocorre devido à incapacidade, ausência e até mesmo a rejeição por parte dos ambientes educacionais que deveriam receber essas pessoas. Desse modo, este trabalho teve por finalidade mostrar como a pessoa com deficiência e/ou necessidades especiais são vistas enquanto profissional da educação, buscando demonstrar que as limitações do corpo em nada interferem em suas capacidades profissionais.

Palavras-Chave: Profissionais com deficiência e/ou necessidades especiais. Acessibilidade. Inclusão. Área temática: Educação Especial. 


\title{
INCLUSÃO X EXCLUSÃO: ENSINO REMOTO PARA ALUNOS DO ATENDIMENTO EDUCACIONAL ESPECIALIZADO
}

\author{
Soraya Gonçalves Celestino da Silva; Fábia Sousa de Sena; \\ Jociellle Sousa de Alfrêdo.
}

O presente artigo tem como objetivo analisar a inclusão ou exclusão dos alunos público-alvo no Atendimento Educacional Especializado (AEE) das redes municipais de ensino de Paulista, Olinda e Recife em Pernambuco, durante as atividades no Ensino Remoto no ano de 2020, devido à Pandemia da COVID-19. O estudo foi conduzido com base em uma pesquisa qualitativa e o instrumento utilizado para coleta de dados foi um questionário aplicado a onze (11) professores do AEE dos municípios supracitados. A análise qualitativa do questionário foi realizada a partir de quatros categorias que compreendem: 1) Quantitativo de alunos deficientes para o AEE em 2020; 2) Quantos alunos foram contemplados com o ensino remoto; 3) Quais recursos tecnológicos foram usados na mediação remota e 4) Se houve efetivação no AEE no cumprimento da inclusão no ensino remoto. Concluimos que o esforço dos professores para manter o contato com esses alunos foi imenso devido a, principalmente, duas dificuldades: a falta de acesso à tecnologia por parte do alunado; dificuldade de acompanhamento pela família e/ou responsável. Quanto à efetividade da inclusão na aprendizagem do ensino remoto, percebemos que o AEE trabalha com estimulação para superar as barreiras dos aspectos da funcionalidade nos estudantes que apresentam maoires dificuldades. $\mathrm{O}$ professor, por conta própria, se reinventou com o intuito de estabelecer uma conexão com aos alunos, sem políticas direcionadas ao longo do tempo, sentiram a responsabilidade em seus ombros, e mostraram que as Ferramentas Virtuais não exclusivas à Aprendizagem (FVNexA) foram os recursos mais usados, com destaque para o WhatsApp, devido às vídeos chamadas realizadas e estavam ao alcance de alguns alunos. Ademais, alguns aspectos deixaram de ser atendidos e impossibilitados de serem avaliados, reforçando a exclusão desses alunos. A descoberta mais relevante foi que a educação inclusiva fica muito prejudicada quando esses alunos não conseguem manter o convívio num ambiente escolar interagindo com os colegas.

Palavras-Chave: Inclusão X Exclusão, AEE, Ensino Remoto.

Área temática: Educação Especial. 


\section{RESUMO SIMPLES -}

\section{INCLUSÃO EDUCACIONAL, DIFICULDADES DE APRENDIZAGEM E POLITICAS PÚBLICAS}


Vinicius Azambuja Ribeiro; Julia de Campos Ferrão;

Leticia Azambuja Lopes.

A falta de conhecimento em relação ao processo de inclusão/exclusão de alunos com deficiência evidencia a necessidade do desenvolvimento de projetos que visem a mudança de paradigma que se explicita através da compreensão e da promoção de novos comportamentos como a empatia. Outro ponto a ser destacado chama a atenção para que haja maior informação acerca da legislação e políticas públicas que envolvem a inclusão. Assim, este artigo possui a finalidade de propor reflexões sobre uma proposta de inclusão que utiliza a metodologia Waldorf, sustentadas em propostas lúdicas potencializadoras do desenvolvimento das áreas: cognitiva e relacional de alunos e professores da rede pública de ensino, do Município de Triunfo, RS. Após a análise de um número significativo de dados, foram descritas as seguintes considerações finais: (1) existe uma carência de informações em relação aos conhecimentos sobre a diversidade dos indivíduos e de como trabalhar com as pessoas que apresentam alguma deficiência; (2) as pessoas envolvidas no projeto aceitaram sem restrições a participarem do estudo; (3) faz-se necessário continuar a investir em projetos inovadores para que a cultura e os modelos de discriminação e exclusão sejam mudados. Notou-se também que o preconceito vem da falta de informação. Pois todos os alunos e professores tiveram o desejo de aprender e a partir das atividades, sendo esses pequenos momentos que aprendemos que existe o diferente, e que acrescentam coisas novas e saberes em nossas vidas, a fim viabilizar o conhecimento, respeito e empatia entre indivíduos.

Palavras-Chave: Deficiência. Inclusão da rede pública de ensino. metodologia lúdica.

Área temática: Inclusão Educacional, dificuldades de aprendizagem e políticas públicas. 
Rodiney Marcelo Braga dos Santos.

Introdução: A educação inclusiva é um paradigma educacional com fundamentos nos diretos humanos que preconiza o direito a todos e a todas por uma educação de qualidade. Já a educação especial é uma modalidade de ensino transversal, ou seja, que perpassa todos os níveis, etapas e modalidades de ensino. Destarte, a educação especial na perspectiva da educação inclusiva é uma proposta pedagógica que tem como princípio a equidade. Objetivo: Refletir sob quais condições a inclusão escolar pode ser efetivada na escola regular. Metodologia: A tipologia da pesquisa é caracterizada pela abordagem qualitativa com caráter exploratório e procedimento bibliográfico. Resultados: Uma das condições para a promoção da inclusão escolar é o (re)conhecimento da singularidade de cada sujeito no lugar constituído pela diversidade. No âmbito dos marcos regulatórios e normativos acerca da educação especial e inclusiva nacionais, que são robustos, podem refletir na promoção de políticas públicas educacionais inclusivas mais efetivas. Os estudantes com deficiências sensoriais, cognitivas e comportamentais e altas habilidade e superdotação, mesmo com o direito ao acesso à escola regular, ainda, experienciam diversas barreiras desde arquitetônica, de transporte, informação, comunicação até atitudinal, assim, a apropriação da tecnologia assistiva, como campo interdisciplinar, pode favorecer condições de alcance para transpor barreiras. Outrossim, a identidade de um currículo para todos, a exemplo, por meio da abordagem do desenho universal para a aprendizagem. Também, a significação do coensino, como o planejamento e a construção coletiva da oferta do serviço de atendimento educacional especializado. Considerações: A inclusão escolar é possível de ser efetivada na escola regular. Para tanto, no movimento da inclusão, a escola deve estar preparada para acolher e promover um ambiente educativo de pertencimento e protagonismo de forma equitativa e justa, ou seja, ao invés do igual, o espaço para o singular.

Palavras-Chave: Educação Inclusiva. Proposta pedagógica. Equidade.

Área temática: Inclusão Educacional, dificuldades de aprendizagem e políticas públicas. 


\title{
IMPASSES DA CONCRETIZAÇÃO DAS LEGISLAÇÕES ESPECÍFICAS VOLTADAS À INCLUSÃO DAS PESSOAS COM DEFICIÊNCIA NO CONTEXTO ESCOLAR
}

\author{
Rodiney Marcelo Braga dos Santos.
}

Introdução: Historicamente o conceito de deficiência esteve associado à incapacidade, imperfeição, impossibilidade e incompletude. No início da década de 80, do século passado, a Organização Mundial da Saúde (OMS) apresentou o termo deficiência relacionado a uma perturbação orgânica. Somente no ano de 2001, propôs uma nova classificação a partir das dimensões biológicas, emocionais e ambientais. Para além das definições técnicas e no âmbito das práticas sociais, a deficiência é marcada pela concepção de anormalidade, ou seja, é expressa na deficiência o valor negativo que reflete em privações. Com efeito, a estigmatização, a marginalização, o preconceito e a discriminação. Assim, o conceito da deficiência pode ser entendido como uma patologia social, ou seja, modelo social da deficiência, que impõe condições excludentes. Objetivo: Identificar alguns impasses da concretização das legislações específicas voltadas à inclusão das pessoas com deficiência no contexto escolar. Metodologia: A tipologia da pesquisa é caracterizada pela abordagem qualitativa com caráter exploratório e procedimentos bibliográfico e documental. Resultados: A título de ilustração, destacamos dois marcos nacionais que embasam as ações em termos de inclusão educacional: as Diretrizes Nacionais para a Educação Especial na Educação Básica (2001) que instituiu as diretrizes para a educação de alunos que apresentem necessidades educacionais especiais, na Educação Básica, em todas as suas etapas e modalidades e a Política Nacional de Educação Especial na Perspectiva da Educação Inclusiva (2009) que conjuga a igualdade e a diferença como valores indissociáveis. Ademais, segue alguns dos impasses da concretização das legislações específicas voltadas à inclusão das pessoas com deficiência no contexto escolar, como: o entendimento restrito da inclusão que reflete em contextos contraditórios e excludentes; a falta da promoção concreta das condições de acesso, participação e aprendizagem; a ausência da família como parte coletiva da comunidade escolar; o sentimento de impotências dos profissionais diante das demandas de uma escola inclusiva e a falta de articulação dos documentos institucionais escolares com o real cenário escolar. Considerações: No que concerne à legislação sobre educação especial e inclusiva, possuímos dispositivos robustos. Todavia, há um descompasso entre os marcos legais e a práticas educativas, o que tardia a efetivação da lógica da inclusão.

Palavras-Chave: Deficiência. Patologia social. Inclusão escolar.

Área temática: Inclusão Educacional, dificuldades de aprendizagem e políticas públicas. 


\section{RESUMO SIMPLES -}

INCLUSÃO NA EDUCAÇÃO PROFISSIONALIZANTE 


\section{A EMPATIA COMO SABER EM INCLUSÃO ESCOLAR PARA FORMAÇÃO CONTINUADA DOS PROFISSIONAIS DA EDUCAÇÃO ESPECIAL NOS IFS}

Ricardo Allan de Carvalho Rodrigues; Maria Cristina Caminha de Castilhos França.

Introdução: o que impulsiona e o que mobiliza a busca de estratégias diversificadas pelos profissionais que atuam no Núcleo de Atendimento às Necessidades Específicas - NAPNE, professores de salas inclusivas, entre outros, no sentido de promover uma educação inclusiva, equitativa e ao longo da vida aos estudantes com deficiência, transtorno geral do conhecimento, altas habilidades ou superdotação, matriculados nos Institutos Federais de Educação, Ciência e tecnologia-IFs? A partir de estudos realizados junto aos profissionais inclusivos de sala de aula ou que atuavam no Núcleo de Atendimento às Necessidades Específicas-NAPNE do Instituto Federal de Brasília - IFB, a empatia foi destacada como saber essencial aos profissionais da Educação Profissional e Tecnológica-EPT que atuavam na inclusão do público da Educação Especial matriculado no IFB. Objetivo: discutir o conceito de empatia apresentado na teoria do tratamento centrado na pessoa, apresentado por Carl Rogers, no contexto das ações e formações iniciais/continuadas de profissionais voltados à inclusão de pessoas público da Educação Especial nos IFs. Metodologia: adotou-se a revisão bibliográfica, por meio de pesquisa exploratória, em que os argumentos são apresentados ordenadamente na forma de ensaio teórico. A revisão sistemática da literatura foi realizada em artigos nas bases de dados Periódicos CAPES e Google Acadêmico, totalizando 31 publicações, entre artigos e teses consultados, sendo 19 utilizados, tendo como descritores: empatia, formação de professores para educação e inclusão na Educação Profissional e Tecnológica. Resultados: entre os resultados percebe-se que a abordagem do tema da empatia nos cursos de formação inicial ou continuada em educação é feita de maneira isolada, por profissionais que atuam em salas ou núcleos de atendimento às necessidades específicas NAPNEs, ao contrário no que ocorre em cursos de formação inicial na área médica. No entanto, uma vez incorporada a empatia tende a beneficiar o trabalha inclusão por todos. Conclusões: entre suas conclusões, a pesquisa considera que o mecanismo da incorporação da empatia nos processos formativos de profissionais inclusivos é resultante de múltiplos fatores, mas que necessita ser estimulado nas formações continuadas, de forma cíclica, dado seu valor na superação de barreias físicas-atitudinais para inclusão escolar na Educação Profissional e Tecnológica - EPT.

Palavras-Chave: Educação inclusiva. Educação profissional e tecnológica. Formação de professores. Área temática: Inclusão na Educação profissionalizante. 


\section{RELATO DE EXPERIÊNCIA SOBRE APLICAÇÃO DE PROJETO DE SINALIZAÇÃO PARA PESSOAS CEGAS E SURDAS NO IFBA CAMPUS JACOBINA}

André Lima.

Este artigo tem por objetivo analisar o impacto na comunidade acadêmica do IFBA Campus Jacobina, da aplicação de um projeto de sinalização visual para o acesso inclusivo de pessoas cegas e surdas, com a finalidade de promover maior autonomia para estes sujeitos, auxiliar no seu desenvolvimento no contexto do espaço escolar e facilitar sua inserção na sociedade contemporânea. Isto posto, é fundamental pensar o papel do design no que diz respeito à concepção de interfaces que busquem reduzir as lacunas sociais demarcadas historicamente e as invisibilidades das pessoas com necessidades específicas no contexto da escola. A metodologia aplicada para concepção dos protótipos e peças gráficas desenvolvidas e apresentadas à comunidade acadêmica foi estruturada com base na metodologia proposta por Bruno Munari, e especialmente foram consultados estudantes com deficiência visual e surdos do campus para possibilitar uma escuta sensível acerca de quais as barreiras de acessibilidades os protótipos poderiam encarar com mais ênfase, respeitando as necessidades de cada estudante. Os dados apresentados nesta pesquisa foram coletados a partir da exposição dos modelos simulados em computação gráfica e o preenchimento de um formulário com questões pertinentes a estes modelos. Os protótipos foram criados em computação gráfica e apresentados à comunidade: um totem com tela sensível ao toque com o programa VLibras instalado, um modelo de mapa do piso tátil de acesso ao campus e placas de sinalização das salas e setores da escola com a descrição em Libras e Braille. A exposição dos modelos em computação gráfica permitiu à comunidade acadêmica vislumbrar e refletir sobre a acessibilidade como possibilidade real da inclusão no espaço educacional, pautar de forma engajada políticas de fomento a projetos acerca da educação inclusiva e cobrar junto aos gestores acadêmicos a concretização das propostas que objetivam diminuir as barreiras que cerceiam a plena realização de uma educação verdadeiramente inclusiva.

Palavras-Chave: Sinalização visual, acessibilidade, pessoa com necessidades específicas. Área temática: Inclusão na Educação profissionalizante. 


\title{
RESUMO SIMPLES -
}

\author{
INCLUSÃO NO ENSINO,DAS CIÊNCIAS \\ (MATEMÁTICA, FISICA, QUÍMICA E BIOLOGIA)
}


Sara Gomes da Silva; Beatriz dos Santos Lopes;

Marina Teófilo Pignati.

Introdução: A poluição hídrica é um problema relevante no cenário nacional, pois a utilização dos recursos hídricos é essencial para a manutenção da vida. Assim, são necessárias práticas que envolvam a sensibilização ambiental para conservação dos recursos hídricos, e uma das formas de promovê-la é por meio do professor na unidade escolar. Os jogos didáticos são ferramentas úteis nesse processo educacional, os quais facilitam o ensino-aprendizado e podem auxiliar no desenvolvimento de alunos com necessidades especiais. Objetivo: Promover a sensibilização ambiental sobre os recursos hídricos, por meio de jogos, em alunos com deficiência intelectual (DI) do $6^{\circ}$ ao $8^{\circ}$ ano do Ensino Fundamental, da Escola Estadual Professor Irineu da Gama Paes em Macapá/AP. Metodologia: 1) Foram realizadas observações dos professores do Atendimento Educacional Especializado (dois professores) e dos alunos com DI (seis alunos), visando a elaboração de uma metodologia eficiente mediante as especificidades de cada educando; 2) Foram aplicadas entrevistas para verificar os conhecimentos prévios dos estudantes, assim como os adquiridos ao longo da intervenção acerca do tema água e, por último, 3) Foram aplicados jogos didáticos (jogo silábico, da memória e da trilha) com a temática recursos hídricos. Resultados: Constatou-se que os alunos com DI apresentaram limitações quanto à leitura, escrita e temporalidade, assim como dificuldades de memorização e atenção. Quanto aos professores, eles utilizam metodologias diferenciadas de ensino, como o uso de jogos digitais, as quais se mostraram eficientes no ensino-aprendizagem em estudantes com DI. Em relação às entrevistas, os alunos já apresentaram um conhecimento prévio sobre a temática água, mas demonstraram um melhor desempenho na entrevista final, após a aplicação das atividades. A respeito dos jogos, todos os estudantes compreenderam as regras, no entanto, o jogo silábico foi a atividade que obtiveram maior dificuldade. Em contrapartida, nos jogos da memória e da trilha, os alunos jogaram com facilidade, havendo empolgação e fixação do conteúdo. Conclusão: Conclui-se que este trabalho contribuiu para a consciência ambiental dos estudantes, e que o uso de jogos didáticos é eficiente no processo de ensino-aprendizagem nos alunos com DI.

Palavras-Chave: Ensino Lúdico. Meio ambiente. Necessidades especiais.

Área temática: Inclusão no ensino das Ciências (matemática, física, química e biologia). 


\section{RESUMO SIMPLES}

OUTRAS ÁREAS AFINS 
Pedro Carlos Silva de Aquino.

Introdução: Este trabalho apresenta um relato da experiência acerca da inclusão de alunos com Transtorno do Déficit de Atenção com Hiperatividade (TDAH) nas aulas de Educação Física no Ensino Fundamental, desenvolvido através do estágio supervisionado III, componente curricular obrigatório do curso de Educação Física da Universidade Regional do Cariri - URCA/CE. Objetivo: Descrever a experiência vivenciada na inclusão de alunos com TDAH nas aulas de Educação Física nos anos finais do Ensino Fundamental. Metodologia: Delineia-se como um relato de experiência caracterizado como uma pesquisa-ação com abordagem qualitativa. $\mathrm{O}$ estudo em questão contemplou dois alunos do sexo masculino, com 11 e 12 anos, das turmas do $6^{\circ}$ e $7^{\circ}$ ano, respectivamente, que apresentava diagnóstico positivo para TDAH, pertencentes aos anos finais do Ensino Fundamental de uma escola da rede pública municipal de Crato/CE. O estágio supervisionado totalizou 54 horas/aula de regência. A referida atividade curricular ocorreu entre março a maio de 2019, contemplando aulas com duração de 50 minutos. O conteúdo desenvolvido na prática pedagógica foram jogos pré-desportivos de característica lúdica relacionada ao Futebol. Resultados: No tocante à prática pedagógica, o estagiário conjuntamente com a docente da disciplina, planejou as intervenções baseadas em estratégias metodológicas que proporcionou a adesão e participação dos 2 alunos com TDAH nas aulas. Entre as crianças com o transtorno que variou entre leve e moderado, foram observadas as seguintes características: comportamento de desatenção; hiperatividade e impulsividade. Dessa maneira, para o desenvolvimento das atividades criou-se vínculos entre professor-aluno e aluno-aluno, para instigar tais crianças a se sentirem parte integrante da turma. Com isso, as atividades foram organizadas na realização de jogos pré-desportivos e cooperativos que promoveram uma aprendizagem mútua e a socialização entre os alunos. Visto que, durante as aulas adotou-se como estratégia pedagógica que as crianças com TDAH fossem os protagonistas do grupo, no qual evitou-se possíveis dificuldades na execução das tarefas e garantiu a atenção e concentração nas aulas. Considerações Finais: Diante da intervenção, a estratégia pedagógica, os procedimentos metodológicos e os conteúdos empregados contribuíram para a inclusão e participação efetiva dos alunos com TDAH nas aulas de Educação Física escolar.

Palavras-Chave: Ensino. Crianças. Transtorno do Déficit de Atenção com Hiperatividade. Área temática: Outras áreas afins. 


\section{A ORGANIZAÇÃO CURRICULAR NA PERSPECTIVA INCLUSIVA}

Rodiney Marcelo Braga dos Santos.

Introdução: $\mathrm{Na}$ última década do século passado, a inclusão, na sua forma ampla, tem sido potencializada como um imperativo mundial. Fazendo um recorte, a inclusão escolar é uma proposição de ação política que tem como objetivo promover um espaço de acolhimento de todos os alunos. Sua diferenciação com base na deficiência assumiu por muito tempo um caráter segregador e excludente. Porém, apesar do avanço quanto à sua integração em espaços escolares comuns, onde temos um cenário em que o sujeito deve se adaptar à normalização da deficiência, ainda, sua singularidade é negligenciada. Todavia, na lógica de suporte, a inclusão ordena a educação especial, enquanto modalidade escolar, com caráter transversal, a promoção do atendimento especializado educacional complementar e/ou suplementar ao processo de escolarização. Objetivo: Compreender a organização curricular na perspectiva inclusiva. Metodologia: A tipologia da pesquisa é caracterizada pela abordagem qualitativa com caráter exploratório e procedimento bibliográfico. Resultados: A proposta curricular inclusiva tem como objetivo respeitar a diversidade que caracteriza o ambiente escolar, ou seja, que responda às necessidades educativas especiais dos alunos. A organização curricular na lógica da inclusão deve ser aberta, dinâmica, interativa, viva e flexível. Apesar, em sua organização anunciar as aprendizagens consideradas essenciais e seja um referencial de educação para todos os alunos, certamente deve considerar as adaptações necessárias para a promoção da participação efetiva e aprendizagens nela sinalizada. Em síntese, as práticas educacionais inclusivas instauram a busca de novas percepções e perspectivas. No que concerne as estruturas curriculares, destacamos alguns pressupostos, como: o (re)conhecimento da singularidade de cada sujeito no lugar constituído pela diversidade; o fortalecimento da ação colaborativa no ato de planejar; a participação na tomada de decisões de todos os agentes envolvidos nas ações educativas; a (re)orientação das abordagens dos objetos de conhecimento no escopo do cotidiano escolar e o conhecimento dos diversos ritmos e estilos de aprendizagem de todos os sujeitos envolvidos. Considerações: O currículo inclusivo deve ser concebido como tomada de transformação para atender à diversidade no ambiente educativo/ escolar na perspectiva de uma educação equitativa, justa e de qualidade.

Palavras-Chave: Educação. Currículo. Inclusivo.

Área temática: Outras áreas afins. 


\section{A EDUCAÇÃO INCLUSIVA NO ENSINO SUPERIOR TEM CONTEMPLADO ESTUDANTES COM TRANSTORNO DO ESPECTRO AUTISTA?}

Erica Etelvina Viana de Jesus.

Introdução: Os dados dos últimos censos do INEP (2015-2019) mostram um aumento progressivo de matrículas no ensino superior de estudantes com Síndrome de Asperger, condição incluída no Transtorno do Espectro Autista (TEA). Entretanto, pouco se tem discutido sobre as vivências desses acadêmicos, bem como sobre as práticas institucionais para garantir sua permanência. Objetivo: O propósito desse estudo foi identificar como o ensino superior brasileiro tem atuado na inclusão de indivíduos com TEA. Metodologia: Foi realizado um levantamento bibliográfico nos diretórios Biblioteca Virtual em Saúde (BVS), Scientific Electronic Library Online (SciELO) e Google Acadêmico, usando descritores relacionados ao tema. Apesar de nenhum critério de exclusão ter sido aplicado, apenas sete artigos atenderam ao objeto de estudo, demonstrando a escassez de discussões sobre a temática. Resultado: A análise dos artigos mostra um despreparo do ensino superior em atender as necessidades dos seus estudantes com TEA. As dificuldades sócio emocionais mostraram ter papel de destaque nas adversidades vivenciadas pelos acadêmicos. Os relatos mais recorrentes foram de bullying, sentimento de isolamento perante os pares, sentimento de inadequação e experiências negativas com atividades em grupo. Apesar da existência de núcleos destinados à inclusão e acessibilidade, nem sempre esses parecem atuar ativamente na promoção de práticas pedagógicas que contemplem e favoreçam o desenvolvimento acadêmico dos estudantes autistas. As abordagens, quando oferecidas, visaram intervenções pontuais no indivíduo, mas sem vislumbrar modificações na estrutura educacional para viabilização do acolhimento dos mesmos, sendo comum o sentimento de não terem sido contemplados pelos referidos programas de inclusão. Outro ponto de relevância foi o aparente despreparo e inaptidão docente em conduzir práticas pedagógicas que oportunizassem aos discentes o enfrentamento das suas dificuldades e progredissem na vida acadêmica. Considerações finais: É possível inferir que o Ensino Superior no Brasil precisa repensar a inclusão para além da garantia de acesso à universidade, mas também no estabelecimento de políticas pedagógicas que garantam uma permanência exitosa, possibilitando não apenas uma participação plena da experiência acadêmica, mas também o desenvolvimento social e capacitação profissional do indivíduo com TEA. Ademais, a carência de literatura sobre o tema enfatiza a necessidade da ampliação de estudos dessa natureza.

Palavras-Chave: Educação especial. Autismo. Universidade.

Área temática: Outras áreas afins. 


\section{RESUMO SIMPLES}

POLÍTICAS EDUCACIONAIS: GESTÃO ESCOLAR, FORMAÇÃO DOCENTE E INCLUSÃO 


\title{
PLANEJAMENTO DE POLÍTICAS EDUCACIONAIS NA LÓGICA DA INCLUSÃO: A META 4 DO PLANO NACIONAL DE EDUCAÇÃO (2015-2025)
}

\author{
Rodiney Marcelo Braga dos Santos.
}

Introdução: Sendo a educação um direito de todos e um dever do Estado e levando-se em consideração a Política Nacional de Educação Especial na Perspectiva da Educação Inclusiva (PNEEPEI) que conjuga a igualdade e a diferença como valores indissociáveis, destacamos a meta 4 do Plano Nacional de Educação (PNE) que está voltada à redução das desigualdades e à valorização da diversidade e o Plano Estadual de Educação da Paraíba (PEE/PB), em virtude de ser nosso cenário focal de atuação profissional, como objetos de estudo. Objetivo: Fazer um estudo comparativo da meta 4 do PNE (2014-2024) com as metas relativas à educação especial do PEE/PB (2015-2025). Metodologia: A tipologia da pesquisa é caracterizada pela abordagem qualitativa com caráter exploratório e procedimento documental. Resultados: A construção do PEE/PB foi coordenada pelo Conselho Estadual de Educação, sendo ativo de sujeitos dos diversos setores da sociedade. No que concerne o aspecto estrutural, foi organizado em 5 tópicos principais: educação básica, educação superior, formação e valorização dos profissionais da educação, gestão democrática da educação e financiamento da educação. Além destes, foi incluído no primeiro tópico a educação para a cultura dos direitos humanos, das relações étnico-raciais e de educação ambiental. Como consequência desta estrutura, o PEE/PB apresenta 28 metas, sendo 20 correspondentes àquelas do PNE, algumas com adequações à realidade local e 8 metas criadas exclusivamente para atender às especificidades anteriormente evidenciadas, ou para contemplar as modalidades de ensino, individualmente, por meta. $\mathrm{O}$ referido plano tem na sua meta 7 o que corresponde à meta 4 do PNE e apresenta estratégias. Para tanto, quanto ao acompanhamento de sua implantação foi instalada a Comissão Estadual de Acompanhamento e Avaliação do Plano Estadual de Educação. Considerações: Para garantir o acesso e a permanência dos estudantes da modalidade de educação especial na escola comum deve ser potencializado o planejamento de políticas educacionais na lógica da inclusão e de acordo com as diretrizes estabelecidas pela PNEEPEI. Constatamos o alinhamento da meta 4 do PNE com as metas relativas à educação especial do $\mathrm{PEE} / \mathrm{PB}$.

Palavras-Chave: Plano Estadual de Educação da Paraíba. Modalidade de ensino. Educação Especial. Área temática: Políticas Educacionais: gestão escolar, formação docente e inclusão. 
Bruno da Silva Santos; Marco Aurélio de Lima;

Silvio Braz de Sousa; José C. S. Barbosa Júnior.

É sempre necessário analisar a formação de professores em Geografia, assim como, a promoção de inclusão de discentes com deficiência nas aulas regulares do ensino básico. Sabe-se que é necessário promover aos licenciandos uma formação acadêmica e profissional adequada, a qual gere condições de aprendizagem durante a sua formação no que se refere a educação inclusiva. Neste sentido, este trabalho realizou um levantamento sobre a capacitação profissional dos docentes que atuam na rede básica de ensino do Rio Grande do Norte, por meio de entrevistas estruturadas, e uma análise das grades curriculares dos cursos de licenciatura em Geografia das principais instituições públicas de ensino superior potiguares (UFRN, UERN e IFRN). Os resultados indicam que a carga horária presente nas matrizes curriculares é muito baixa em relação a carga horária total do curso, oscilando entre $1,85 \%$ a $4,18 \%$ dependendo da instituição de ensino e da modalidade ofertada pelo curso. Tendo em vista os resultados de entrevista estruturada, onde $94 \%$ dos professores da rede básica de ensino apontam uma formação deficitária das graduações e a baixa aprovação das características das grades curriculares dos cursos por parte dos professores universitários das instituições selecionadas; bem como, a baixa adesão dos cursos às disciplinas voltadas para a inclusão, observado através de pesquisas, fica constatado a necessidade de intervenção no processo de formação do licenciando em relação a educação inclusiva nas graduações de geografia na modalidade licenciatura.

Palavras-Chave: Cartografia. Inclusão e acessibilidade. Residência Pedagógica.

Área temática: Políticas Educacionais: gestão escolar, formação docente e inclusão. 


\section{A IMPORTÂNCIA DO PAPEL DO PROFESSOR EM TEMPOS DE PANDEMIA: ENFRENTANDO DESAFIOS}

Aziel Alves de Arruda; Andressa de Brito Silva;

Bianca Carneiro da Silva; Maria Hyannes Silva de Souza.

Este trabalho surgiu de uma inquietação teórico-prática que foi percebida a partir de uma vivência como voluntária no Centro de Ensino Fundamental Manoel Burgos em que constatamos a insegurança dos professores frente aos desafios que surgiram no contexto educacional com a chegada da pandemia. A pesquisa aborda a importância do papel do professor em tempos de pandemia e os desafios a serem enfrentados no contexto escolar, tendo como premissa compreendermos o papel do professor na pandemia e discutir as dificuldades e contribuições deste contexto para as práticas pedagógicas. Para fundamentar a análise deste estudo utilizamos os autores que falam da temática: Franco (2012), Nóvoa (1992), Pimenta (2012) Franco (2015), Proença (2018), Santos (2020), Senhoras (2020), Garcia (2020). Os autores estudados contribuíram na construção metodológica fundamentada no procedimento qualitativo com investigação dos argumentos concedidos em entrevistas com os professores dos anos iniciais do ensino fundamental do Centro de Ensino Fundamental Manoel Burgos no município de Timbiras-MA. A temática em questão nos faz refletir sobre a profissão docente no aspecto de termos um olhar holístico da profissão, sobretudo no que diz respeito a sua formação e ao seu papel na sociedade. Considerando esses aspectos, constatamos que se tem uma necessidade de o município investir na capacitação desses professores para que possam atuar com perfeição. Devemos considerar que investir em formação profissional é de suma importância para melhoria das práticas educacionais. É necessário dar uma perceptividade a essa indagação no sentido de instigar a presença de professores em cursos de formação que contribuam e valorizem suas vivências, por conseguinte auxiliar em sua formação.

Palavras-Chave: Professores. Pandemia. Ensino Remoto.

Área temática: Políticas Educacionais: gestão escolar, formação docente e inclusão. 
RESUMO EXPANDIDO EDUCAÇÃO ESPECIAL 


\title{
EDUCAÇÃO E PANDEMIA: O ATENDIMENTO EDUCACIONAL ESPECIALIZADO \\ NUMA ESCOLA MUNICIPAL DA ZONA RURAL
}

\author{
Telma da Silva Amorim¹. \\ ${ }^{1}$ Graduanda em Pedagogia, Faculdade Ieducare (FIED), Tianguá, Ceará.
}

PALAVRAS-CHAVE: Atendimento Educacional Especializado (AEE). Atividades remotas. Pandemia.

ÁREA TEMÁTICA: Educação Especial.

\section{INTRODUÇÃO}

Por muito tempo, as pessoas com deficiência foram excluídas da sociedade, e vistas até mesmo como incapazes de exercerem funções iguais aos demais. Atualmente, após muitas lutas, essas pessoas podem estar inseridas em todos os ambientes econômicos, e inclusive, tendo direitos à educação. A educação inclusiva hoje tem por objetivo a inclusão das pessoas com deficiência e o acesso ao ensino. De acordo com a lei n $n^{\circ} 9.394$ de Diretrizes e Bases da Educação Nacional (LDB), assegura a oferta da educação especial desde a educação infantil e ao longo da vida (BRASIL, 1996). Além do acesso à educação, as instituições têm por meio, oportunizar a sala multifuncional para os alunos com deficiência, tendo como objetivo proporcionar uma melhor qualidade ao processo de aprendizagem a estes discentes.

Segundo o Decreto n 7.611 o Atendimento Educacional Especializado (AEE) é "compreendido como o conjunto de atividades, recursos de acessibilidade e pedagógicos organizados institucional e continuamente." (BRASIL, 2011). O AEE não substitui o ensino regular, mas funciona como uma sala multifuncional para alunos com deficiência e com atendimentos realizados por um docente especializado. Entretanto, os atendimentos acontecem para melhorar o processo de aprendizagem dos alunos através de intervenções que o possibilitem adquirirem conhecimento da melhor forma possível, sendo um complemento para a aprendizagem do aluno.

Devido à pandemia do Covid-19, as escolas tiveram que ser fechadas para evitar a contaminação do vírus com os demais profissionais que atuam na educação. Contudo, o ensino passou a ser mediado através das tecnologias, objetivando aos docentes seguir a proposta do Conselho Nacional de Educação (CNE), que orientou a adotar o Ensino Remoto Emergencial (ERE), visando diminuir os impactos causados pelo afastamento dos alunos da escola. Desta forma, algumas dificuldades surgiram diante o ensino remoto, que vai desde o acesso a internet até mesmo a participação dos alunos nas aulas remotas. A pesquisa visa o atendimento educacional especializado de uma escola localizada na zona rural perante o contexto de pandemia. Neste aspecto, tem-se o seguinte questionamento: quais os desafios do atendimento educacional especializado para os alunos com deficiência perante a pandemia? 
Neste sentido, frente ao seguinte questionamento, o objetivo geral pretende analisar como está sendo feito o atendimento educacional especializado dos estudantes com deficiência em uma escola localizada na zona rural, no município de Tianguá, Ceará. Desta forma, a pesquisa tem como relevância conhecer de acordo com a realidade dos docentes as dificuldades encontradas através do ensino remoto e quais as alternativas utilizadas para conseguir mediar o atendimento educacional especializado por meio das tecnologias.

\section{METODOLOGIA}

A pesquisa é de natureza qualitativa, que tem como objetivo principal analisar o atendimento educacional especializado dos estudantes com deficiência em uma escola localizada na zona rural, no município de Tianguá, Ceará. Desta forma, Teixeira (2006) afirma que, na pesquisa qualitativa, as experiências são essenciais para o aprimoramento da compreensão do estudo.

Para a obtenção dos resultados, utilizou-se um questionário com 12 perguntas, para alcançarmos a resposta da seguinte problemática abordada. O questionário foi elaborado através do Google Forms e enviado via link pelo WhatsApp para a professora investigada. Segundo Gil, defini-se o uso de questionário como "a técnica de investigação composta por um número mais ou menos elevado de questões apresentadas por escrito às pessoas, tendo por objetivo o conhecimento de opiniões, crenças, sentimentos, interesses, expectativas, situações vivenciadas entre outras" (1999, p.128). Esta técnica de pesquisa busca a aquisição de respostas de acordo com as vivências descritas pelo o docente.

\section{RESULTADOS E DISCUSSÕES}

O Decreto $\mathrm{n}^{\mathrm{o}} 7.611 / 2011$ afirma garantir perante o sistema educacional a oferta de apoio necessária para os alunos com deficiência, ou seja, o atendimento educacional especializado para atender os alunos nas salas multifuncionais com intuito de melhorar a aprendizagem. A sala multifuncional é um ambiente equipado com recursos pedagógicos e paradidáticos e adequado aos discentes.

A pesquisa teve como amostra a participação de uma professora que atua na sala de Atendimento Educacional Especializado (AEE) em uma escola municipal localizada na cidade de Tianguá, Ceará. A partir da coleta dos dados, sobre a formação docente, a mesma possui graduação em Pedagogia e pós-graduação em Gestão Escolar e Metodologias do Ensino Fundamental e Médio. Atua há 23 anos como docente e 1 ano e 5 meses na sala multifuncional.

Em decorrência da pandemia do Covid-19, as escolas tiveram que ser fechadas, com isso, para evitar o afastamento dos alunos da escola, o Conselho Nacional de Educação (CNE) adotou que o ensino aconteceria a partir das tecnologias, o contato entre aluno e professor passou a ser mediado através das tecnologias. Com relação à pergunta sobre como tem sido o atendimento educacional especializado dos estudantes com deficiência diante o período de ensino remoto, a professora respondeu que, o atendimento acontece via teleatendimentos semanais e atividades impressas. 
Quando perguntada sobre as dificuldades encontradas na sua prática com o atendimento educacional especializado, a professora afirmou algumas como: dificuldades com a utilização das tecnologias, estimular a atenção e realização de atividades, rejeição por parte de algumas crianças às aulas remotas e a falta de parceria de algumas famílias. Além disso, a mesma relatou que no início as dificuldades foram maiores, mas sempre busca ajuda do núcleo gestor e coordenação municipal. No que se refere aos desafios enfrentados e para melhorar a sua prática, a professora busca manter contato direto com a família, elabora atividades e atendimentos dinâmicos e sempre respeita o limite e necessidade de cada criança. Entretanto, a professora ressaltou entre as dificuldades diante o ensino remoto, que os alunos demonstram inquietação frente ao uso das tecnologias, ansiedade e a falta de devolução das atividades propostas.

Ao ser questionado com relação ao planejamento das atividades para os alunos com deficiência, a professora respondeu que o planejamento acontece mensalmente, buscando sempre alcançar individualmente as habilidades a serem desenvolvidas com o aluno. A respeito da participação do professor da sala regular no planejamento, a mesma relatou que não há participação dos demais docentes da sala regular.

A formação continuada é de suma importância para o docente, possibilitando o aprimoramento de conhecimentos a serem desenvolvidos para ser trabalhado com os discentes, visando uma melhor qualidade ao processo de aprendizagem. Com isso, quando perguntada se o município oferece formação continuada aos docentes que atuam na sala multifuncional, a professora destacou que sim, e citou algumas formações como: Um olhar para transformar, Uso de novas mídias, Jornada pedagógica, O uso das ferramentas tecnológicas na Educação Especial: ressignificar a prática e Congresso de conscientização do Autismo. Sobre os materiais disponibilizados aos alunos, não foi possível obter respostas. Em questão da formação continuada, a professora não tem outras formações como pósgraduação voltada para o atendimento educacional especializado, mas, participa das formações ofertadas pelo município e CREAECE.

Com o fechamento das escolas em decorrência da pandemia do Covid-19, as tecnologias têm sido essenciais para o contexto atual, contudo, para que o atendimento aconteça entre professor e aluno, o uso do WhatsApp, Google Meet, biblioteca virtuais, aplicativo luz do saber, blogs, site escola games e entre outros, estas ferramentas digitais estão sendo utilizadas para o atendimento, com intuito de ser mais dinâmico. Atualmente, a professora do AEE atende 13 alunos.

A participação da família é essencial para o desenvolvimento das habilidades do aluno no ambiente educacional, portanto, a escola tem por meio estar em conjunto com todos para que haja o processo de ensino e aprendizagem. Com a ausência dos professores e sem o contato presencial, os mesmos tiveram que contar com a família para que a aprendizagem dos alunos com deficiência aconteça, pois, os pais têm sido importantes para ajudar no ensino remoto. Desta forma, em relação à participação da família e escola, a professora afirmou que possui uma boa relação com algumas famílias. 


\section{CONSIIDERAÇÕES FINAIS}

Diante a pandemia do Covid-19 e com as medidas tomadas para conter a circulação do vírus entre as pessoas, as escolas tiveram que ser fechadas para que alunos e professores não fossem infectados. Desta forma, a pandemia trouxe um grande impacto em específico no setor educacional, com isso, o Conselho Nacional de Educação (CNE) adotou que as aulas aconteceriam a partir do uso das tecnologias, com intuito de cumprir com o calendário letivo e diminuindo os impactos do afastamento dos alunos da escola. A professora investigada da seguinte escola teve que adaptarse com as tecnologias para que o processo de ensino-aprendizagem dos alunos que utilizam a sala multifuncional aconteça.

A pesquisa procurou analisar como está acontecendo o atendimento educacional especializado de uma escola localizada na zona rural no município de Tianguá, Ceará. Após o envio de um questionário com algumas perguntas relacionadas sobre o atendimento dos alunos com deficiência diante o ensino remoto, obteve-se que, a professora que atua na sala multifuncional, tem realizado os atendimentos via teleatendimentos, ou seja, utilizando as tecnologias digitais da melhor forma possível e dinâmica para interagir com os discentes e promovendo o processo de ensino e aprendizagem. Os atendimentos continuam acontecendo de forma remota, o que de certa forma surgem algumas dificuldades entre o aluno e professor, pois, a seguinte professora, relatou que os alunos demonstram inquietação frente às tecnologias, falta de participação com algumas famílias e as devoluções das atividades que muitas vezes não é reenviada de volta.

De acordo com os resultados obtidos desta pesquisa, a pandemia tem causado certas dificuldades para o docente que atua na sala multifuncional e ao aluno, a prática esta sendo desafiadora para os profissionais, entretanto, os demais precisam contar com a participação da família para que aconteça o processo de ensino aprendizagem dos alunos.

\section{PRINCIPAIS REFERÊNCIAS}

BRASIL. Lei No 9.394, de 20 de Dezembro de 1996. Estabelece as diretrizes e bases da educação nacional, 1996. Disponível em: < http://www.planalto.gov.br/ccivil_03/Leis/L9394.htm >. Acesso em: 29 de ago. 2021.

BRASIL. Decreto N 7.611, de 17 de Novembro de 2011. Dispõe sobre a educação especial, o atendimento educacional especializado e dá outras providências, 2011. Disponível em: < http://www. planalto.gov.br/ccivil_03/_ato2011-2014/2011/decreto/d7611.htm >. Acesso em: 29 de ago.2021.

GIL, A. C. Métodos e técnicas de pesquisa social. 5.ed. São Paulo: Atlas, 1999.

TEIXEIRA, E. As três metodologias: acadêmica, da ciência e da pesquisa. $2^{\mathrm{a}}$ ed. Petrópolis, RJ: Vozes, 2006. 203 p. 


\section{Eduarda Letícia Sousa Pereiraํㅜ Milena Moreira Santana²; Zilda Tizziana Santos Araújo³}

${ }^{1}$ Estudante, Universidade Estadual do Piauí (UESPI), Piripiri, Piauí.

${ }^{2}$ Estudante, Universidade Estadual do Piauí (UESPI), Piripiri, Piauí.

${ }^{3}$ Docente, Universidade Estadual do Piauí (UESPI), Piripiri, Piauí

PALAVRAS-CHAVE: Dificuldade de aprendizagem. Educação. Aplicativos.

ÁREA TEMÁTICA: Educação Especial.

\section{INTRODUÇÃO}

Este estudo objetivou compreender o que é dislexia e como professores podem fazer uso de tecnologias educacionais como ferramentas de apoio no processo de alfabetização de crianças disléxicas no contexto da inclusão e do ensino remoto, deixando evidente o que são essas tecnologias e de que forma elas contribuem nesse processo.

A vasta literatura sobre Dislexia, possibilitou-nos compreender que a mesma não se trata de uma doença, mas, sim, de um transtorno específico de aprendizagem (Santos, 2014), e que mesmo não existindo cura, necessita de tratamento especializado com suporte de uma equipe multidisciplinar.

A partir desse entendimento, o presente estudo buscou elencar ferramentas tecnológicas, aplicativos digitais, disponíveis para utilização como recursos pedagógicos que auxiliem o professor no processo de alfabetização de crianças com dislexia, visto que, aplicativos de jogos educativos trazem inúmeras contribuições para o ensino e aprendizagem do educando, tornando esse processo mais significativo, atrativo e prazeroso. Segundo Lévy (1999), a utilização das TDIC como instrumentos da nossa cultura, tem aumentado e também a sua utilização como uma ferramenta de inclusão digital e interação com o mundo, procedendo disso nesta pesquisa foram analisados os aplicativos Domlexia e Lumosity.

A motivação para a realização deste estudo partiu do interesse em aprofundarmos o conhecimento acerca das possibilidades pedagógicas que aplicativos digitais podem trazer ao processo de alfabetização de alunos disléxicos, pois acredita-se que tal estratégia seja eficaz e que quando as escolas disponibilizam materiais e recursos digitais para apoiar professores alfabetizadores de alunos com dislexia, a aprendizagem destes alunos pode ser potencializada.

Nesse contexto de pandemia, em que o professor não tem a possibilidade de acompanhar presencialmente o progresso da aprendizagem dos seus alunos, faz-se necessária a mediação por meio de de Tecnologias Digitais da Informação e Comunicação (TDIC), bem como a participação dos pais durante esse processo, principalmente no caso de alunos com dislexia que carecem de uma prática 
pedagógica especializada.

Isto posto, considerando o cenário de ensino remoto atualmente vivenciado em diferentes contextos, acreditamos que a utilização de plataformas, ferramentas e aplicativos digitais podem auxiliar os professores e os próprios discentes, mesmo que à distância, a mitigar o déficit de ensino aprendizagem. E, com isso, caminhamos na direção contrária à fragmentação desse processo, por esse motivo consideramos que este resumo é de extrema relevância.

\section{METODOLOGIA}

Esta pesquisa, de cunho bibliográfico fez um estudo em artigos (SANTOS, 2021; LANFREDI, 2018) disponíveis na base do Scientific Electronic Library Online (Scielo) e em plataformas digitais sobre tecnologias digitais voltadas para o contexto educativo, a fim de buscarmos elementos com dados pertinentes sobre o objeto em estudo e, assim, obtermos uma melhor percepção acerca do uso de tecnologias educacionais digitais que auxiliam no processo de alfabetização de alunos com dislexia.

$\mathrm{O}$ entendimento do tema foi adquirido através da leitura das fontes encontradas por meio da pesquisa bibliográfica na Internet, através de uma ampla busca por sites, aplicativos de jogos educativos, livros, artigos científicos, teses de autores que possuem obras voltadas para a conceituação e entendimento sobre dislexia e tecnologias educacionais que assistem o professor no processo de alfabetização para alunos com esta dificuldade de aprendizagem.

\section{FUNDAMENTAÇÃO TEÓRICA}

A dislexia se caracteriza como um transtorno específico na leitura e na escrita, que faz com que alunos que apresentam esse transtorno tenham algumas dificuldades no desenvolvimento do aprendizado. Esse transtorno torna-se mais evidente e perceptível durante o processo de aquisição da leitura e da escrita, segundo Almeida (2005, p.1. Apud LOPES, 2007, p.3) "A dislexia não é uma doença, então não se pode falar em cura e sim de tratamento, onde pode ser controlada com acompanhamento especializado".

Assim, para ensinar alunos com esse transtorno de aprendizagem, o professor necessita realizar adaptações pedagógicas no exercício da sua prática, uma vez que atua como mediador nesse processo. Para esse fim o professor pode trabalhar usando as TDIC. Segundo Silva (2019, p. 28), “A cada dia as TICS se tornam mais presentes no cotidiano escolar e vêm se tornando uma importante ferramenta no processo de ensino e aprendizagem".

Dessa forma, fica evidente que a tecnologia educacional potencializa a aprendizagem do educando com dislexia e maximiza suas capacidades. Seguindo essa linha de pensamento, foram analisados neste estudo dois aplicativos para dispositivos móveis que podem atuar como recursos pedagógicos para auxiliar o professor no processo de alfabetização de alunos com dislexia. 
O primeiro aplicativo analisado foi o Domlexia, que está disponível para Android e IOS, e foi desenvolvido pela educadora Nadine Heisler e pela fonoaudióloga Sabrina Luz segundo o site www.domlexia.com.br/sobre-nos. O referido aplicativo é em formato de jogo de celular, com o nome "o jogo dom e as letras", é disponibilizado de forma gratuita, oferecendo, também, uma versão paga. Convém ressaltar que esse aplicativo diferencia-se de outros, pois apresentam uma versão para escolas cadastradas em seu projeto, o Escola Dom, e, caso a escola se interesse pelo seu aplicativo ela pode entrar em contato com os responsáveis e após o cadastro a escola recebe um código que pode ser inserido no início do jogo, disponibilizando a versão para todos os seus alunos.

O Domlexia tem a proposta bastante interessante de trabalhar a alfabetização que pode ser utilizada pelo professor, o jogo está dividido em fases, em cada fase existe um grupo de letras, e o jogo se consiste em você identificar se as imagens dos objetos que aparecem têm o nome começando pela letra que foi mostrada logo no início, através disso o professor pode está iniciando ou dando continuidade na alfabetização da criança, de forma remota e com o auxílio dos pais ou responsáveis da criança com dislexia.

O Lumosity, disponível para Android e IOS, também é outro aplicativo que pode auxiliar o professor no ensino aprendizagem de alunos com dislexia, ele foi lançado em 2007, desenvolvido pelo Lumos Labs, segundo o site www.lumosity.com/pt/, está disponível nos idiomas: Português, Inglês, Espanhol, Francês, Alemão, Japonês e Coreano.

Esse aplicativo oferece tarefas e jogos personalizados com a idade e a formação acadêmica de cada participante, tais informações são solicitadas ao jogador logo no início e o próprio aplicativo faz um um cronograma exclusivo com jogos cognitivos especializados, personalizando, assim, as etapas e graus de dificuldade. disponibilizando também uma versão paga, porém a versão gratuita disponibilizada não tem potencial pedagógico para ser utilizada no processo de alfabetização de alunos com dislexia, o mais recomendando do uso desse aplicativo é a versão paga, nela é oferecida jogos onde o professor pode trabalhar desde o raciocionio lógico, a velocidade, a memória à atenção que seria a principal ferramenta pedagógica do professor no auxílio da alfabetização.

\section{CONSIIDERAÇÕES FINAIS}

O presente estudo realizou uma pesquisa sobre aplicativos que podem ser utilizados para a alfabetização de crianças com dislexia. Discutiu-se sobre dois aplicativos: o Domlexia e o Lumosity, e pela análise dos mesmo foi possível identificar que: apesar do Lumosity ter uma significativa quantidades de jogos e ser personalizado para cada pessoa, ele só disponibiliza gratuitamente uma pequena quantidade de funcionalidades; já o Domlexia têm um maior potencial na proposta de auxiliar na alfabetização, pois além da simplicidade e fácil manuseio do aplicativos, é disponibilizado gratuitamente para as escolas que tiverem o interesse de utilizar essa ferramenta tecnológica no seu ensino aprendizado e também com sua programação feita exclusivamente voltada para a alfabetização, diferente do Lumosity que foi programado para conter várias funções de uso, o Domlexia apresenta uma forma de letramento ao mesmo tempo inovadora e simplista. 
Concluímos com esse estudo que mesmo com aplicativos inovadores para o auxílio do professor no processo de alfabetização de crianças com dislexia, o acesso total a eles ainda é ponto de bastante dificuldade, as versões gratuitas disponibilizadas pelos aplicativos não podem suprir a necessidade requerida de auxiliar no ensino-aprendizagem, e apesar de as versões pagas poderem sim suprir essa necessidade, entra a grande questão de quem poderia custeá-las, mas como já apresentado o aplicativo Domlexia oferece um programa para as escolas disponibilizando a versão premium, sendo assim uma saída para que os professores possam disponibilizar esse tipo de recurso tecnológicos aos seus alunos com dislexia.

\section{REFERÊNCIAS}

LANFREDI, Caila. Aplicativos para dispositivos móveis como ferramentas de apoio à aprendizagem de estudantes com dislexia. In: Anais do Seminário Internacional de Educação, Tecnologia e Sociedade, 23., 2018, Moodle. Metodologias Ativas. Taquarq: Núcleo de Educação On-line, 2018, p. 1-9.

GAlVÃO FILHO, T. A. A Tecnologia Assistiva: de que se trata? Redes Editora:Porto Alegre, 2009.

DOMLEXIA. Disponível em: https://www.domlexia.com.br/. Acesso em: 24 jul. 2021

LUMOSITY. Disponível em: https://www.lumosity.com/pt/. Acesso em: 24 jul. 2021. 


\section{Milena Meneses de Carvalho ${ }^{1}$; Andressa da Silva Carvalho²; Ricaelle Coelho Castelo Branco ${ }^{3}$; Zilda Tizziana Santos Araújo ${ }^{4}$.}

${ }^{1}$ Graduanda do curso de Pedagogia da Universidade Estadual do Piauí, Universidade Estadual do Piauí ( UESPI ), Piripiri, Piauí.

${ }^{2}$ Graduanda do curso de Pedagogia da Universidade Estadual do Piauí, Universidade Estadual do Piauí ( UESPI ), Piripiri, Piauí.

${ }^{3}$ Graduanda do curso de Pedagogia da Universidade Estadual do Piauí, Universidade Estadual do Piauí ( UESPI ), Piripiri, Piauí.

${ }^{4}$ Mestra em Educação pela Universidade Federal do Piauí, Docente do curso de Pedagogia na Universidade Estadual do Piauí, Universidade Estadual do Piauí ( UESPI ), Piripiri, Piauí.

PALAVRAS-CHAVE: TEA. Ensino Remoto. Prática Docente.

ÁREA TEMÁTICA: Educação especial.

\section{INTRODUÇÃO}

O principal objetivo é compreender como está ocorrendo a inclusão escolar de alunos com Transtorno de Espectro Autista (TEA) em tempos de pandemia. Para tanto, o interesse de investigação voltou-se à ação docente prática educacional e as estratégias pedagógicas para os alunos com TEA por meio de aulas remotas, devido à pandemia do vírus Covid-19. . Mudanças foram necessárias, pegando a todos de surpresa, trazendo inúmeras problemáticas a serem pensadas e resolvidas. . O Tea tem várias definições dentre elas a de um transtorno de ordem neurobiológica, provocando algumas alterações no comportamento, na interação ou até mesmo na comunicação.( Schwartzman e Araújo ( Apud Freitas, 2016, p.16).

O processo de ensino para crianças com deficiências ou transtornos globais, como o TEA, passou por muitas mudanças, negativas e positivas, entre as conquistas temos a Lei Brasileira de Inclusão (LBI) que institui o Estatuto da pessoa com Deficiência, Lei n ${ }^{\circ}$ 13.146/2015 (BRASIL, 2015), garantindo e protegendo inúmeros direitos desse público, dentre eles, frequentar uma escola. Além dos direitos já estabelecidos pela Constituição Federal de 1988, como também o Estatuto da Criança e Adolescente (ECA). A temática proposta partiu da inquietação de pensarmos e discutirmos as dificuldades e o trabalho realizado pelo corpo docente para atender as necessidades de todos os alunos em tempos remotos, sem exclusões. Portanto, o foco da pesquisa é o público do TEA, visto que é igualmente importante pensar e discutir o atendimento a estas crianças, sem prejudicar seu desenvolvimento apesar das dificuldades. 


\section{METODOLOGIA}

Esta pesquisa é de natureza Qualitativa (MINAYO, 2001) do tipo exploratória, visto que, por meio de um questionário destinado a professores que trabalham com o AEE, foi possível discutir e refletir sobre a prática pedagógica pensada para crianças com TEA em tempos de pandemia. A pesquisa e produção deste trabalho ocorreram de forma remota, entre os meses de julho e agosto do ano de 2021, por conta da covid-19. Os professores participantes trabalham na cidade de Barras Piauí, sendo estes um total de 3 educadores, que serão nomeados no presente texto como professores A, B e C, a fim de preservarmos suas identidades. As 9 perguntas propostas no questionário tiveram como foco descobrir como está ocorrendo o planejamento das atividades para alunos neurodiversos e,também, sobre a qualidade do ensino para essas crianças com TEA, durante o ensino remoto.

\section{RESULTADOS E DISCUSSÕES}

É perceptível que a sociedade passou e passa por diversas transformações, alterando seus paradigmas. "A inclusão, portanto, implica mudança desse atual paradigma educacional, para que se encaixe no mapa da educação escolar que estamos retraçando. É inegável que os velhos paradigmas da modernidade estão sendo contestados e que o conhecimento, matéria prima da educação escolar, está passando por uma reinterpretação." (MANTOAN, Maria, 2003, p. 12), com isso, notamos a importância de buscar a cada dia melhorar nossa forma de ver a sociedade. Surgiram Leis para que a sociedade entendesse as pessoas com deficiência vê- las por uma outra perspectiva. Uma Lei que garante direitos às pessoas com Transtorno do Espectro Autista( TEA) é a Lei Brasileira de Inclusão no 13.146, de 6 de julho de 2015, "Essa lei ainda define que, por vias operacionais na educação, serão públicos da Lei Brasileira de Inclusão os alunos com deficiência física, intelectual, sensorial e múltipla, que demandem atendimento especializado, os alunos dentro do Espectro Autista e os alunos com altas habilidades e superdotação"(DAMBROS, 2018, p. 58). Como aponta Fernandes (2013, p. 35), as pessoas que eram consideradas "anormais" passaram a ser ligadas a situações que o ser humano não entendia, associando ao espiritual.

Considerando o objeto de estudo e os objetivos deste trabalho, a seguir serão discutidas as concepções e experiências enfrentadas por esses professores em seu dia a dia através da análise dos depoimentos dos 3 entrevistados. Iremos compreender através desta pesquisa como tem sido desafiador repensar na prática em tempos remotos e como se tem enfrentado essas dificuldades para que haja mudanças significativas e duradouras. Quando perguntamos à Professora A, como os alunos com TEA têm se desenvolvido com as mudanças da rotina escolar? Ela nos respondeu da seguinte forma: 
Professora $A$-"Leva um tempinho para adaptação. Temos que respeitar o tempo de cada um e suas necessidades individuais, pois cada criança responde de forma diferente. As intervenções vão acontecendo de acordo com as especificidades de cada aluno e de cada turma. A parceria com a família é essencial para o sucesso do aprendizado deles."

Nesta fala é reafirmada a importância da parceria entre os pais e a escola, de um planejamento onde todos são envolvidos. A Declaração de Salamanca ressalta que é importante "promover e facilitar a participação de pais, comunidades e organizações de pessoas com deficiência no planejamento e no processo de tomada de decisões para atender a alunos e alunas com necessidades educativas especiais.”(SALAMANCA, 1994, p. 2). A professora B, falou também em relação a parceria entre pais/escola, quando lhe perguntamos se os pais estão tendo alguma relutância ou dificuldade em meio ao novo contexto que estamos vivendo, como por exemplo, aulas remotas. E a resposta foi: Professora $B$ - "Sim, para os pais está sendo um desafio, pois nem todos estão preparados pedagogicamente com metodologias e didáticas."

Com essa fala, percebemos a realidade de muitos pais de crianças com TEA, que estão tendo que lidar com um novo contexto, diferente da rotina escolar presencial, pois, antes, os seus filhos iam à escola e recebiam um reforço para realizar as atividades, e, agora esse papel tem sido atribuído, em grande parte, à família, trazendo um grande desafio. "A cooperação, portanto, é um esforço necessário que forma uma base sólida no processo de intervenção quando cuidada tanto por pais quanto por professores". (BRUNI; MACEDO, 2013, p. 76). Ainda falando sobre esta relação, a professora $C$, traz uma questão que também merece destaque, pois em sua fala ela comenta sobre a troca de informações que há entre ambas as partes e que juntas podem aprender e se desenvolver. Ela relata que: Professora $C$ - "Temos uma boa relação com os pais, há sempre troca de experiências e dialógo".

Em relação à inclusão escolar de alunos com TEA, em sala regular, é importante salientar que a união de pais com o corpo docente da escola é fundamental. Pois, para se ter um acompanhamento de forma mais efetiva, é necessário o feedback de ambas as partes. Conforme Bruni e Macedo (2013, p. 78) "Estratégias simples de troca entre pais e professores sempre usados de forma positiva podem servir também para comunicar os ganhos comportamentais do aluno em cada ambiente." Percebemos assim que essa troca de informações entre pais e professores é uma das formas de contribuir para o planejamento pedagógico.

\section{CONSIDERAÇÕES FINAIS}

Diante dos argumentos e reflexões expostas podemos compreender o grande desafio que o corpo de professores vem enfrentando em desenvolverem as aulas remotas que sejam inclusivas para alunos com TEA, em razão das medidas de biossegurança impostas por conta da pandemia do Covid-19.. A didática usada durante esse momento deve ser um pouco mais atenciosa, planejada, articulada e leve, pois assim como é difícil para os professores ressignificarem sua prática é também 
para os alunos e seus pais estando em casa acompanharem, se manterem atentos e conseguirem atingir os objetivos pedidos pelos professores. Não é preciso de muito para que seja feito algo significativo na prática, mas para isso é necessário que haja dinâmica, ludicidade, ferramentas que chamem a atenção desses alunos e os ajudem a compreender e se adaptar ao mundo virtual, para que quando eles voltem às aulas presenciais não sintam tanta dificuldade em continuar seu processo de aprendizagem.

\section{PRINCIPAIS REFERÊNCIAS}

FERNANDES, Sueli. Fundamentos para educação especial. Curitiba: Ibpex, 2013.

MANTOAN, Maria. Inclusão escolar: O que é? Por quê? Como fazer?. São Paulo: Moderna, 2003.

DECLARAÇÃO de Salamanca - 1994: Declaração de Salamanca e linha de ação sobre necessidades educativas especiais. Espanha, 1994.

DAMBROS, Aline. Inclusão de alunos com transtorno do espectro autista: Um estudo em contexto de escolarização no Estado de São Paulo. Maringá, 2018.

Família e escola: Parceiras na inclusão. In: BRUNI, Ana, MACEDO, Livia. Cartilha Autista e Educação. São Paulo, 2013.

FREITAS, D. Relações de cuidado em processos terapêuticos - educacionais junto a pessoas diagnosticadas com Transtorno do Espectro do Autismo. Tese (Doutorado - Programa de Pósgraduação em Psicologia) - Instituto de Psicologia, Universidade de São Paulo. São Paulo, 2016. 


\section{Lucineide Oliveira Silva ${ }^{1}$; Juliana Cristina Salvadori²; Crizeide Miranda Freire ${ }^{3}$.}

${ }^{1}$ Mestre em Educação e Diversidade, UNEB - Jacobina-BA.

${ }^{2}$ Doutora-Literaturas de Língua Portuguesa, UNEB - Jacobina-BA.

${ }^{3}$ Mestre em Educação e Contemporaneidade, UNEB - Jacobina-BA.

PALAVRAS-CHAVE: Escola. Deficiência. Acessibilidade.

ÁREA TEMÁTICA: Educação Especial.

\section{INTRODUÇÃO}

O trabalho ora exposto é o recorte da pesquisa "Espaço escolar e os processos de inclusão e exclusão de alunos com deficiência: estudo de caso em Junco/BA", apresentada ao Programa de Pós-Graduação em Educação e Diversidade, no ano de 2018. O processo investigativo apoiou-se na pesquisa qualitativa através do método de Estudo de Caso, numa perspectiva Etnográfica, sendo necessária uma descrição densa na interpretação do conteúdo. Como colaboradores nessa caminhada tivemos integrantes da comunidade escolar como: professores da sala comum e de recursos multifuncional, corpo diretivo, profissionais de apoio, alunos com deficiência e familiares. Para tanto, três categorias de análises emergiram durante a pesquisa: Inclusão e exclusão; Acessibilidade; Espaço. Assim, elegemos a categoria espaço para essa discussão. Sob a ótica de Santos (1988), em seu livro Metamorfose do espaço habitado, espaço é conceituado como um encadeamento de formas construídas coletivamente e, portanto, em constante movimento e reconfiguração. Santos (1988) afirma que o espaço se torna reflexo da ação do homem sobre o próprio espaço que são mediados entre si pelos objetos naturais e artificiais. As representações do autor sobre espaço, coincidem com o que analisamos sobre o espaço escolar como produtor e reprodutor de ações coletivas que implicam na inclusão ou exclusão a partir dos seus movimentos internos e externos.

\section{OBJETIVO}

Compreender como o espaço escolar produz e reproduz os processos de inclusão e exclusão de alunos com deficiência.

\section{METODOLOGIA}

Apesquisa foi realizada com enfoque qualitativo, pois buscou estudar e interpretar os fenômenos que se constituem das e nas relações entre os sujeitos de pesquisa em seus espaços (GATTI; ANDRÉ 2013, p.34). O método foi Estudo de Caso Etnográfico, que sob a definição dos autores Hernández, 
Collado e Lucio (2006) é útil para assessorar e desenvolver processos de intervenção em pessoas, famílias, organizações, países etc., e desenvolve recomendações ou cursos de ação a serem seguidos. A técnica para desenvolver o estudo de caso etnográfico foi a Descrição Densa, que, para Geertz (2008), é concernente à interpretação realizada da leitura do contexto fático descrito, juntamente com os aspectos que o permeiam, quais sejam, motivações, objetivos e significados, que ultrapassam os limites de uma descrição, é em si uma interpretação. Sendo que o conteúdo interpretado "é o fluxo do discurso social e a interpretação envolvida consiste em tentar salvar o 'dito' num tal discurso da sua possibilidade de extinguir-se e fixá-lo em formas pesquisáveis” (Ibdem, p.15).

\section{RESULTADOS E DISCUSSÕES}

Piletti (2014, p. 19), em seu livro Entre os fios e o manto: tecendo a inclusão escolar, destaca que a diversidade está cada vez mais presente nos espaços sociais, como a escola, com o direito e o dever de ocupar os seus espaços, em um processo de tensionamento identitário, entre inclusão e exclusão, que gera outros sujeitos. A reflexão da autora nos forneceu subsídios para uma discussão sobre estes outros está cada vez mais presente(s) no espaço escolar. Para garantir a estadia e a transformação do espaço escolar, é preciso pensar em tornar a escola hospitaleira e não hostil a essa diversidade (MIRANDA, 2013, p.3). O espaço escolar foi apresentado e debatido nesse estudo como ponto fundamental para entendermos a necessidade de se criar possibilidades para a acessibilidade de alunos com deficiência em uma realidade onde a exclusão se faz presente e é revelada pelos colaboradores da pesquisa como um ponto vulnerável tanto no contexto escolar como na sociedade. Como resultado das entrevistas no que se refere ao espaço da escola, o corpo diretivo, os professores e os profissionais de apoio concordaram quanto a necessidade da melhoria e ampliação do espaço físico da escola para adequar-se às necessidades dos alunos com deficiência. As famílias dos alunos com deficiência consideraram em sua maioria que a escola não possui espaço com acessibilidade arquitetônica. Os alunos com deficiência, por sua vez, analisaram que o espaço da escola precisava ser mais organizado e com instrumentos de acessibilidade para atender as suas necessidades. Assim, consideramos que a escola é um campo fértil de oscilações emocionais principalmente quando a inclusão de alunos com deficiência é cerne da questão.

\section{CONCLUSÃO}

Garantir o cumprimento dos direitos das pessoas com deficiência é demanda ética que as instituições escolares e as redes das quais fazem parte, tem parcialmente atendido, pelo menos discursivamente. Contudo, é preciso sair do campo dos discursos para as práticas que norteiam e precisam ser acessadas e trazidas à tona, reorientando-as para melhor atender os alunos com deficiência celebrando a inclusão escolar. A partir dos resultados alcançados por meio dos dados sobre espaço e acessibilidade da escola, optamos por elaborar um plano de ação interventivo. O plano de ação é uma ferramenta utilizada para planejar ações necessárias quando queremos atingir metas em um campo específico. Estamos ainda em processo de aplicação do plano de ação com formações dialogais para os atores educacionais da pesquisa membros da Escola Municipal pesquisada. Do 
espaço pesquisado, fizeram emergir reflexões quanto a projeto que reforce junto ao poder público municipal, a necessidade de acessibilidade arquitetônica e pedagógica para os alunos com deficiência. Os resultados demonstraram a fragilidade do espaço da escola para o acolhimento do aluno com deficiência. A exclusão de forma geral ocorre a partir dos discursos ditos e não ditos, das ações e da falta sensibilidade para a causa da inclusão e que perpassa pelo poder público municipal. Dialogamos, porém não foram sanadas em definitivo as nossas inquietações. Por fim, esperamos impulsionar a Escola Municipal pesquisada, no sentido de tornar a sua cultura mais inclusiva com vistas nas políticas nacionais de inclusão, as quais não são implantadas por conta própria e merecem ser avaliadas e postas em prática de forma coletiva, o que dará ainda mais sentido ao nosso estudo.

\section{REFERÊNCIAS}

GATTI, B. A; ANDRÉ, M. A relevância dos métodos de pesquisa qualitativa em Educação no Brasil. In:

WELLER, Wivian; PFAFF, Nicolle. (Org.). Metodologia da pesquisa qualitativa em Educação. 3. ed. Petrópolis, RJ: Vozes, 2013.

GEERTZ, C. 1926. A interpretação das culturas. Rio de Janeiro: LTC, 2008. 323p.

HERNÁNDEZ, S. R; COLLADO, C. F; LUCIO, P. B. Metodologia de pesquisa. Tradução Fátima Conceição Murad, Melissa Kassner, Sheila Clara Dystyler Ladeira; Revisão técnica: Ana Gracinda Queluz Garcia. Paulo Heraldo Costa do Valle. 3. ed. São Paulo: McGraw-Hill, 2006.

MIRANDA, J. V. A. Alteridade e o paradoxo da hospitalidade na educação. $36^{\text {a }}$ Reunião Nacional da ANPEd - 29 de setembro a 02 de outubro de 2013, Goiânia-GO, 2013. Disponível em:http://www. anped.org.br/sites/default/files/gt17_3051_texto.pdf. Acesso em: 09/05/2018.

PILETTI, A. C. C. Entre os fios e o manto: tecendo a inclusão escolar. São Paulo: Edições Loyola, 2014.

SANTOS, M. Metamorfoses do espaço habitado: fundamentos teórico e metodológico da geografia. São Paulo: Hucitec, 1988. 


\section{Ciris Alves da Silva ${ }^{1}$; Fernanda de Sousa Macarenhas² ${ }^{2}$ Zilda Tizziana Santos Araújo ${ }^{3}$.}

${ }^{1}$ Graduanda, Universidade Estadual do Piauí (UESPI), Piripiri, Piauí.

${ }^{2}$ Graduanda, Universidade Estadual do Piauí (UESPI), Piripiri, Piauí.

${ }^{3}$ Mestra em Educação (UFPI), Docente na Universidade Estadual do Piauí (UESPI), Piripiri, Piauí.

PALAVRAS-CHAVE: Ensino remoto. AEE. Alunos com surdez.

ÁREA TEMÁTICA: Educação Especial

\section{INTRODUÇÃO}

O presente trabalho traz uma discussão sobre o Atendimento Educacional Especializado (AEE) para Alunos com Deficiência Auditiva no Âmbito do Ensino Remoto. A partir desta temática, buscamos compreender, na perspectiva dos professores, quais os desafios e dificuldades encontrados no desenvolvimento do AEE para alunos com surdez no contexto do ensino remoto provocado pela pandemia do SARS-CoV-2, e ainda como está ocorrendo esse atendimento. Isso porque o ensino remoto tornou-se necessário para que acontecesse a realização dessas atividades.

Sabemos o quão difícil é o ensino em sala de aula presencial e, principalmente, a inclusão desses alunos que precisam de um atendimento diferenciado, tendo nesse caminho, que lidar com um novo modelo de educação para que seja possível o ensino aprendizagem. Deslocando tal questão para o ensino remoto emergencial, conjectura-se que os desafios e dificuldades possam ser maiores, uma vez que a oferta das atividades de ensino e de mediação pedagógica no AEE tende a um nível maior de complexidade, pelo próprio contexto. $\mathrm{O}$ acesso do aluno com surdez, consequentemente, torna-se mais difícil e isso pode trazer prejuízos ao processo de acompanhamento das aprendizagens desse público-alvo da educação Especial.

Diante disso, é importante estarmos conscientes sobre a realidade do ensino através do meio virtual, pois há muitos fatores que interferem, sendo um deles a acessibilidade, que nem todos têm. Para compreendermos melhor sobre a importância do Atendimento Educacional Especializado (AEE) para alunos com deficiência auditiva, faz-se necessário termos o conhecimento sobre o que é AEE e qual sua principal característica, o que as bases legais garantem para essas crianças e quais atividades e estratégias podem e devem ser oferecidas no AEE para alunos com deficiência auditiva. O AEE é o Atendimento Educacional Especializado, que tem como principal característica identificar, elaborar e organizar recursos pedagógicos e de acessibilidade que eliminem as barreiras para a plena participação dos alunos, considerando suas necessidades específicas. Ele funciona como um serviço de apoio à sala de aula. Para os estudantes surdos, o atendimento escolar acontece em duas línguas: 
Libras e Língua Portuguesa.

\section{METODOLOGIA}

Este estudo assenta-se na pesquisa do tipo qualitativa, de caráter exploratório. O método qualitativo de pesquisa é aqui entendido como aquele que se ocupa do nível subjetivo e relacional da realidade e do contexto comum, estudado através da narrativa, dos interesses e dos comportamentos de alguns grupos sociais. Teve como lócus duas escolas da rede pública do município de Piripiri que ofertam o AEE e atendem alunos com surdez. A população desta investigação foi composta por dois professores que atuam em escolas públicas em salas de AEE, lotados em 2021 nos lócus mencionados anteriormente. A seleção dos participantes aconteceram através de chamadas de ligação e por mensagens via aplicativo de WhatsApp. Esses professores serão identificados ao longo do texto como (P1), (P2). Para a realização deste trabalho, foi aplicado um questionário que, para Gil (1999), é uma técnica de investigação composta por um número elevado de questões dissertativas, de modo redigido ao pessoal entrevistado, tendo por finalidade a percepção de seus pontos de vista, convicções, vivências, possibilidades. Este foi o método utilizado para obter a produção dos dados. Dessa forma, o desenvolvimento da pesquisa ocorreu remotamente, sendo o questionário enviado por meio de aplicativo de WhatsApp contendo cinco perguntas. O período no qual essa etapa da pesquisa ocorreu foi de 08/2021 a 09/2021.

\section{RESULTADOS E DISCUSSÃO}

O exemplo da inclusão mostra como deve ser o acesso e o direito que todos os estudantes têm de estarem em sala de aula e em espaço coletivo, compreendendo e favorecendo, sem que haja qualquer motivo de discriminação, levando assim, ensinamentos sobre a educação inclusiva ao mesmo tempo que busca questionar e não permitir sobre qualquer forma de exclusão.

A Declaração de Salamanca deixa claro os pontos que devem ser tratados no que diz respeito à Educação Especial, ou seja, é preciso incentivar a inclusão na educação, ampliar o conceito de necessidades educacionais especiais, ter enfoque na educação de crianças com deficiência, ocorrer no sistema regular de ensino e que as escolas atendam às especificidades de cada aluno, pois independente das diferenças individuais, a educação é um direito de todos. A Lei Brasileira de Inclusão reafirma esses pontos quando fala no artigo $1^{\circ}$ reservado a garantir e viabilizar, de modo igualitário, o direito primordial das pessoas com deficiência, buscando assim sua inclusão no âmbito social e de cidadania. No contexto de ensino remoto, faz-se necessário que a comunidade escolar repense as suas estratégias de ensino no AEE e que busque meios facilitadores nesse processo, em função das necessidades de aprendizagem e desenvolvimento diferenciado que cada aluno, público-alvo da educação especial, necessita. 
A Lei de Diretrizes e Bases da Educação Nacional (LDBEN), nº 9.394 de dezembro de 1996, reconhece o direito que todo cidadão tenha acesso à educação, assegurando que isso aconteça através de profissionais adequados e capacitados, de modo que os alunos possam participar nas salas de aula comuns. Através do questionário respondido pelos professores de Atendimento Educacional Especializado (AEE), percebemos em suas respostas que existe uma grande preocupação para que de fato aconteça o ensino aprendizagem no atendimento aos alunos com deficiência auditiva. (P1) - Temos usado de instrumentos digitais para levarmos o ensino aos nossos alunos... São preparados vídeos com conteúdos educativos em libras e também uma apostila quinzenal com conteúdos aos alunos surdos.

Pela fala acima, foi revelado que o participante tem utilizado recursos imagéticos impressos pelo professor, lives com legendas em libras (janelas em libras), ou seja, os alunos têm uma parte de sua educação vinculada a vídeos e outra parte por meios impressos. Com isso, fica claro que é preciso repensar as atividades e aulas propostas, fazendo adaptações para promover a inclusão de todos os educandos. Existem alguns aspectos específicos, como a utilização de vídeos e filmes legendados, imagens que transmitam conceitos.

Em relação ao serviço prestado pelo AEE, o acesso do aluno às atividades complementares ou suplementares nas Salas de Recursos Multifuncional (SRM) tem sido, na maioria dos contextos, também de maneira remota. E, considerando as especificidades desse público, há de se pensar nas dificuldades por eles vivenciadas, bem como pelos docentes que os acompanham. Quando perguntamos sobre as dificuldades e desafios encontrados durante o percurso de aulas remotas, as respostas foram que há sim, P2 -As dificuldades existem, na verdade o ensino por si só, é desafiador, principalmente quando envolve uma outra língua, no caso, a libras.

O AEE para alunos com deficiência auditiva é realizado com um professor formado em libras, em um ambiente em que seja utilizada a língua de sinais como a primeira língua e a língua portuguesa como segunda língua. Dessa maneira, o AEE em libras oferece o ensino teórico, ao mesmo tempo em que possibilita a participação na sala de aula regular.

Acrescentaram ainda: (P1) -[...] Falta apoio de algumas famílias e motivação dos alunos em querer aprender [...]. Ocasionando assim um maior impedimento no processo de ensino aprendizagem.

Por fim, destacaram o papel do profissional de AEE: (P2) - No planejamento, o papel desse profissional é pensar no aluno em suas especificidades, dificuldades e capacidades, dando apoio e adaptando recursos para que tenham êxito na formação.

Com base nessa afirmação, compreende- se que o aluno com deficiência deve ter todo o suporte da escola para o desenvolvimento de suas habilidades, pois esses educandos não são seres limitados, mas sim com habilidades diferenciadas. 


\section{CONSIIDERAÇÕES FINAIS}

Com base no resultado da pesquisa, os participantes têm utilizado dos recursos apropriados para alcançar, durante o ensino remoto, a aprendizagem de seus alunos com deficiência auditiva. Por meio desse trabalho, foi alcançado o objetivo deste estudo em compreender as dificuldades e desafios encontrados por professores de AEE para ofertar a educação aos alunos com deficiência auditiva no ensino remoto emergencial. Os principais desafios apontados foram: a falta de conectividade, a questão do apoio familiar, além da desmotivação. E quanto às estratégias para superar tais desafios e promover um atendimento com melhor qualidade, visando o desenvolvimento de habilidades, as que mais se destacam são: utilização de recursos apropriados, além da busca em se reinventar e redefinir sua própria maneira de ensinar. As dificuldades apontadas foram: alunos com baixa conectividade e pouco apoio familiar. Esta pesquisa revelou que ainda existem lacunas em relação ao ensino para alunos com surdez e que o contexto do ensino remoto tem sido desafiador.

\section{REFERÊNCIAS}

BRASIL, lei $\mathrm{n}^{\circ} 13.146$, de 06 de julho de 2015, intituir a lei brasileira da inclusão da pessoa com deficiência. Disponível em http://www.planalto.gov.br/ccivil_03/_ato2015-2018/2015/lei/113146. htm.

GARCIA, Ana keila Castro; ABREU, Waldir Ferreira. Concepções inclusivas de Paulo Freire na educação de surdos, ANAIS do V congresso paraense de educação especial. Marabá- de 17 a outubro de 2018.

JUNIOR, Manoel Osmar Seabra; LACERDA, Lonise Caroline Zengo. Atendimento educacional especializado: planejamento e uso de recursos pedagógicos, revista brasileira de educação 2018.

BRASIL, lei n9.394, de 20 de dezembro 1996, estabelece as diretrizes e bases da educação nacional. Disponível em: http://portal.mec.gov.br > legislacao 


\title{
Letícia da Silva Feitosa'; Nayane da Silva Alves²; Zilda Tizziana Santos Araújo³
}

\author{
${ }^{1}$ Graduanda, Universidade Estadual do Piauí (UESPI), piripiri, Piauí. \\ ${ }^{2}$ Graduanda, Universidade Estadual do Piauí (UESPI), Piripiri, Piauí.
}

${ }^{3}$ Mestre em educação UFPI, Docente na Universidade Estadual do Piauí (UESPI), Piripiri, Piauí.

\begin{abstract}
PALAVRAS-CHAVE: Intervenção. Autismo. Aprendizagem.
ÁREA TEMÁTICA: Educação Especial.
\end{abstract}

\section{INTRODUÇÃO}

O presente estudo apresenta questões sobre o trabalho do Neuropsicopedagogo no atendimento de crianças com Transtorno do Espectro Autista (TEA), voltando o olhar para a importância do mesmo e de sua área de estudo, a Neuropsicopedagogia, no atendimento e tratamento dessas crianças. Partindo do pressuposto de que as mesmas estão dentro do espectro autista e precisam de um acompanhamento profissional que atenda a todas as suas necessidades, pois os mesmos convivem com alguns sintomas que implicam em uma condição diferente de aprendizagem, por conta desse transtorno do neurodesenvolvimento afetar a capacidade de interação, comunicação e comportamento. Assim, esses aprendentes, que são neurodiversos, sentem muita dificuldade de concentração e socialização, ficando muitas vezes isolados no seu mundo particular, não conseguindo também lidar com alguns sentimentos como as frustrações. (PIRES, 2020).

Segundo Fonseca (2014) A Neuropsicopedagogia, é a área do conhecimento que estuda, dentre outras coisas, os processos psicognitivos responsáveis pela aprendizagem, tendo uma enorme importância no trabalho com crianças neurodiversas, por auxiliar as mesmas com a estimulação cognitiva, fazendo com que elas desenvolvam as habilidades ainda não dominadas. Logo, essa área estuda, principalmente, o funcionamento do cérebro para o aprendizado, ou seja, como o aprendizado acontece, já que o ser humano aprende de dentro pra fora. Essa área tem dois ramos em que o Neuropsicopedagogo pode atuar, a institucional e a clínica, cada uma com suas características próprias. Os aprendentes neurodiversos, alunos com TEA, quando acompanhados por uma equipe multiprofissional que possua um neuropsicopedagogo, tendem desenvolver habilidades que estejam em déficit e ampliarem o seu potencial de aprendizagem. (SPOLIDORIO, 2021).

Esse estudo é de suma importância, pois compreender o autismo é um movimento complexo que requer aprofundamento da temática. Tendo como objetivo principal estudar a maneira como o Neuropsicopedagogo trabalha com crianças com autismo, suas técnicas, a importância desse trabalho para a evolução psicognitiva, além da contribuição para o melhoramento do ensino aprendizado de 
alunos com dificuldades na aprendizagem.

\section{METODOLOGIA}

Este estudo foi de natureza bibliográfica e qualitativa, com abordagem descritiva, no intuito de obter informações acerca do trabalho do Neuropsicopedagogo no atendimento de crianças com TEA e de sua área de atuação na identificação e tratamento de crianças que apresentam características que estão dentro do espectro autista, levando, assim, à compreensão dos principais métodos aplicados e as estratégias utilizadas para a obtenção dos melhores resultados possíveis. Os dados foram produzidos por meio da aplicação de um questionário aberto, com 9 (nove) questões, enviado através do aplicativo de conversa WhatsApp no dia 31/08/2021 a 01(uma) profissional atuante nas áreas da Neuropsicopedagogia clínica e institucional, residente na cidade de Piripiri-PI. A participante não terá seus dados revelados, sendo aqui identificada como Neuropsicopedagoga 1(N1), considerando-se a ética na pesquisa que orienta o anonimato dos envolvidos.

\section{RESULTADOS E DISCUSSÕES}

Poderíamos listar muitos pontos sobre as contribuições do Neuropsicopedagogo no trabalho com as crianças autista, no que se refere aos passos e métodos utilizados por ele no momento do atendimento, levando em consideração as especificidades de cada criança. E um dos aspectos que nos foi colocado pela profissional entrevistada, foi: "É preciso primeiro ter certeza dos sinais e da confirmação através de laudos. Este é primordial, visto que é o CID que classifica o grau, em seguida utilizar instrumentos adequados ao nível de classificação em que se encontra o paciente, realizar as seções bem sequenciadas e a cada uma delas fazer a avaliação da evolução do paciente. Posterior às avaliações o profissional deve elaborar o relatório de avaliação Neuropsicopedagógico (RAN), com qualidade, segurança e eficácia para os encaminhamentos necessários”.

A partir dessas considerações, entendemos que o acompanhamento do professor e demais agentes da escola para fazer o diagnóstico e em seguida fazer o encaminhamento é primordial, já que o Neuropsicopedagogo não faz diagnóstico, ele apenas dar o parecer, uma hipótese diagnóstica, tendo por base informações complementares. Segundo Cunha (2013), existe a necessidade de antes da aplicação de qualquer método a fim de ser trabalhado com a criança autista, uma observação minuciosa precisa ser feita pelo professor com o objetivo de descobrir os gostos e as técnicas que funcionam e as que não funcionam com cada criança de forma particular, a família também cabe nessa fase. Pois é a partir desse passo que os demais passos poderão ser realizados.

Outra questão a ser abordada é as habilidades que o profissional da área da Neuropsicopedagogia pode trabalhar com esses aprendentes, a partir disso a entrevistada comentou da seguinte forma: Utilizar atividades, instrumentos e estratégias adequadas ao estágio que o mesmo já possui, reforçar e identificar competências desejáveis para a idade série. Sempre atento à questão da faixa etária e ao desenvolvimento sensorial. 
Levando-nos a entender que são muitas as habilidades que podem ser trabalhadas e, que antes da utilização de qualquer uma delas sempre é importante estar atento às características de cada paciente, pois esta é regra básica que todo profissional deve seguir para conseguir fazer um atendimento apropriado.

A Neuropsicopedagogia possui duas áreas de atuação a institucional e a clínica, a primeira o profissional tem como espaço de atuação instituições como escolas e seu trabalho acontece de forma coletiva, em grupos, já na segunda vertente a clínica, o atendimento é de forma individualizada em espaços muitas vezes particulares como consultórios. Mas não é o espaço utilizado que distingue uma da outra e sim o tipo de atendimento realizado. Diante da necessidade de uma compreensão maior a respeito das duas, foi feita a seguinte pergunta à N1: Quais os benefícios da Neuropsicopedagogia clínica para os autistas? E a resposta obtida foi: "Evolução tanto nas habilidades das funções executivas, como nas competências sensoriais da aprendizagem e no desenvolvimento psicomotor, tendo como objetivo promover, reintegrar o ser humano de forma pessoal e social a partir da identificação, do diagnóstico, da reabilitação e da prevenção de dificuldades e distúrbios da aprendizagem”.

Assim, a mesma deixa expresso que por meio desse trabalho é possível alcançar um crescimento favorável para a criança, no que se refere às evoluções de suas habilidades.

Quanto às ações do profissional de Neuropsicopedagogia, no contexto da educação inclusiva de crianças neurodiversas, Sahb (2004, p.6 ) afirma "que deve haver a preocupação em fornecer igualdade de oportunidades ao acesso ao ensino escolar, ou seja, a criação de uma nova escola que seja regida por princípios de igualdade, equidade e respeito". Por isso mesmo fizemos esta pergunta: Qual o papel da Neuropsicopedagogia? E a participante respondeu: Estudar o funcionamento do cérebro, de forma a entender como ele aprende, seleciona, transforma, memoriza, elabora e processa as sensações captadas pelos elementos sensoriais ao seu redor. Habilitar pessoas para avaliar crianças e adolescentes com queixa escolar.

Assim, compreende-se que seu papel principal é fazer um estudo preciso do cérebro a fim de contribuir para o desenvolvimento de crianças e adolescentes com distúrbios da aprendizagem, fazendo com que elas possam entender suas dificuldades e assim ter um suporte para enfrentá-las e superá-las, havendo assim acolhimento e inclusão.

\section{CONSIDERAÇÕES FINAIS}

Trabalhar com crianças neurodiversas é sempre um desafio, pois é necessário ir muito além daquilo que a escola oferece. Com base nos resultados da pesquisa realizada, conclui-se que a presença de um Neuropsicopedagogo na vida cotidiana dessas crianças e das pessoas que trabalham com ela é muito importante, pois o mesmo buscará estratégias que ajudarão ambos nesse processo, propiciando assim para a evolução de diversas habilidades do aluno.

Os principais desafios encontrados são justamente o de entrar no meio familiar do aluno, desde a gestação até o momento atual, a fim de encontrar vestígio de algum trauma adquirido, por isso esse papel crucial da família, é um trabalho que precisa de muita paciência, atenção, sensibilidade e 
acima de tudo se mostrar seguro diante do paciente. Diante disso, conclui-se que a observação sempre será a parte principal para que aconteça um diagnóstico preciso e um trabalho bem feito que traga benefícios positivos para a criança.

\section{REFERÊNCIAS}

SILVEIRA, Rafael da. O que faz um Neuropsicopedagogo?.Recife: Caderno de estudos e pesquisa na educação básica, 2019.

AVELINO, Wagner Feitosa. A Neuropsicopedagogia no cotidiano escolar da educação básica. Revista educação em foco, 2019.

TOMAZINI, Alex Sandro. A Neurociência e seus benefícios na educação de crianças com autismo. São Paulo: Revista Valores, 2018. 


\section{RESUMO EXPANDIDO}

INCLUSÃO EDUCACIONAL, DIFICULDADES DE APRENDIZAGEM E POLÍTICAS PÚBLICAS 


\section{Juliana Mota Lima ${ }^{1}$; Larissa Mota Cerqueira ${ }^{2}$; Juliana Cristina Salvadori ${ }^{3}$.}

${ }^{1}$ Mestra em Educação e Diversidade - MPED; Universidade do Estado da Bahia - UNEB; Conceição do Coité, Bahia.

${ }^{2}$ Mestra em Educação e Diversidade - MPED; Universidade do Estado da Bahia - UNEB; Jacobina, Bahia.

${ }^{3}$ Doutora em Programa de Pós-graduação em Letras e Linguística pela Pontifícia Universidade Católica de Minas Gerais, Professora Titular da Universidade do Estado da Bahia

PALAVRAS-CHAVE: Inclusão. Educação especial. Escolarização.

ÁREA TEMÁTICA: Inclusão Educacional, dificuldades de aprendizagem e políticas públicas.

\section{INTRODUÇÃO}

Na luta pela inclusão, como paradigma educacional, merecem destaque a Declaração de Jomtien (UNESCO, 1990), a Declaração de Salamanca (UNESCO, 1994) e a Declaração de Guatemala (UNESCO, 1999). Todas essas declarações possibilitaram que uma educação inclusiva fosse construída, pois compreendem que "as escolas inclusivas devem reconhecer as necessidades diversas de seus alunos, acomodando ambos os estilos e ritmos de aprendizagem e assegurando uma educação de qualidade a todos" (UNESCO, 1994, s.p.).

O processo educacional brasileiro pensou a escolarização de pessoas com deficiência como modalidade à parte, denominada educação especial, ofertada, em grande parte, por instituições especializadas, geralmente de origem filantrópica, direcionada para os identificados como deficientes. Segundo Mattos (2014, p. 38), desde os primórdios “a educação especial esteve a cargo de instituições especializadas, mantidas pelo poder público e ou por instituições assistencialistas na tradição do atendimento filantrópico voltado para as populações pobres, desvalidas".

A partir do final do século XX - mais precisamente com a universalização da educação e, no Brasil, com a promulgação da Constituição Federal (BRASIL, 1988), o Estado tornou-se responsável por garantir que a educação especial não fosse mais ofertada como modalidade substitutiva, mas como complementar, garantindo que a escolarização da pessoa com deficiência ocorresse preferencialmente na rede regular. A LDB (BRASIL, 1996), por sua vez, criou o serviço especializado de atendimento às crianças com deficiências nas escolas regulares. Assim, todos esses documentos propuseram e asseguraram avanços significativos para a educação escolar de pessoas com deficiência, promovendo a dignidade humana, pautando-se pelos princípios de igualdade de condições, acesso e permanência no ambiente escolar, assim como a garantia de acesso a níveis cada vez mais elevados no sistema educacional (MANTOAN, 2008). 
Neste sentido, o presente artigo objetivou: Apresentar narrativas e trajetórias históricas da educação especial na Bahia; Descrever o processo de escolarização de surdos na Bahia; Demostrar a existência e importância dos estudos e eventos sobre a educação especial e inclusiva.

\section{METODOLOGIA}

De acordo com a metodologia descritiva, serão apresentados a seguir um recorte dos dados da revisão sistemática, a qual foi realizada em Trabalhos de Conclusão de Curso, de Pesquisas do Mestrado Profissional em Educação e Diversidade (MPED) realizadas nos anos de 2018.2 a 2020.2.

\section{RESULTADOS E DISCUSSÕES}

Em meados do século XX, tem-se início algumas ações da sociedade baiana e do setor educativo para com a deficiência, como a fundação, entre 1952 e 1962, da primeira escola especializada na área de surdez e se inicia também a organização de grupos de especialistas, seguindo o modelo americano de "comitês" (BAHIA, 2017, s.p.).

Também, neste mesmo período houve a fundação do Instituto Pestalozzi (1954), durante a gestão do Secretário de Educação da Bahia, o Sr. Dorival Passos (1950-1955), inicia-se uma articulação do Governo para atender ao público de pessoas com deficiência intelectual, através de uma parceria que estabelecia a prestação de serviços de algumas professoras vinculadas à rede. Nesse período, o Estado enfrentava dificuldades para efetivar a institucionalização do sistema educacional como secretaria, conforme determinava a Constituição Brasileira de 1947, visto que, na época, não havia nenhuma lei estadual que regulamentasse a sua autonomia administrativa e financeira (BAHIA, 1976, apud BAHIA, 2016, s.p.).

Na década de 1980, o serviço de educação especial sofre grandes transformações. No Brasil, a promulgação da nova Constituição (Brasil, 1988), regulamentava, no art. 208, inciso III, a oferta do "atendimento educacional especializado aos portadores de deficiência preferencialmente [devera] ser na rede regular de ensino" (Brasil, 1988, s.p.). Com isso, a educação especial começou a ser reestruturada, sendo criada a Gerência de Educação Especial que nesse primeiro momento estava vinculada ao Departamento de Ensino.

O Governo do Estado da Bahia criou, em 1992, o Centro de Educação Especial da Bahia, que ofertava serviços educacionais de itinerância, ou seja, o atendimento dos alunos não mais acontecendo em escolas especiais. A estrutura desse centro é modificada com a constituição da "coordenação da educação especial, na qual havia uma equipe técnica responsável para cada área da deficiência (intelectual, visual e auditiva)" (BAHIA, 2017, s.p.). Durante muito tempo esse foi o único centro de atendimento de crianças com algum tipo de deficiência da Bahia. O cenário muda com a criação do primeiro centro de educação especial fora da capital - Centro de Apoio Pedagógico, em Feira de Santana, no ano de 2002, "com o objetivo de oferecer serviços educacionais especializados ao público da Educação Especial residente naquela região" (BAHIA, 2017, s.p.). 
Em 2005, como ressonância da Lei no 10.436 (Brasil, 2002) e do Decreto no 5.626 (BRASIL, 2005), a Escola Wilson Lins é designada como Centro de Capacitação dos Profissionais de Educação e Atendimento às pessoas com surdez (Bahia, 2017). É de suma importância compreender que as transformações ocorridas nesse estado não são medidas isoladas, mas acompanham o movimento da educação em nível nacional. Segundo as DIE-BA, no início do século XXI as classes especiais foram fechadas e a nova proposta era de enturmar os alunos oriundos dessas classes em escolas regulares, com um limite de cinco alunos com deficiência por classe, devidamente assistidos pelos profissionais de apoio especializado através de ensino itinerante (BAHIA, 2017).

Segundo dados do Instituto Brasileiro de Geografia e Estatísticas - IBGE (2019), no Brasil, há em média 45 milhões de pessoas com algum tipo de deficiência, o que equivale a 23,9 \% da população. Sendo a região nordeste aquela que se destaca com o maior percentual $(26,63 \%)$ de pessoas que tem algum tipo de deficiência.

O censo de 2010 (IBGE, 2019) também revelou que na Bahia há 3.558.895, pessoas e dessas cerca de 23,39\% (mais de 800 mil pessoas) tem algum tipo de deficiência. Nesse estado, teve início em 2014, a construção das DIE-BA, tendo como um dos seus objetivos: Nortear e balizar ações para uma práxis pedagógica sensível e humanizadora, capaz de promover experiências significativas na construção de saberes por todos os sujeitos, independentemente das suas diferenças culturais, sociais, de gênero, de formas de aprendizagem (BAHIA, 2017, s.p.).

É com esse contexto dialogando entre os dados do IBGE (2010) e os dados SEDPE (2019), e pautando o histórico a educação inclusiva na Bahia, que nasce o questionamento norteador desta pesquisa que busca entender a ausência de estudantes surdos na rede estadual regular de Conceição do Coité, principalmente nos anos finais da educação básica - daí a relevância de se compreender, por meio de suas narrativas, o processo de escolarização vivido por esses sujeitos.

Nessa perspectiva, as categorias escolarização e experiências de/com surdos buscam potencializar as práticas de educação inclusiva com alunos surdos, dialogando com os aparatos legais e teóricos. O cotidiano de/com os surdos, as experiências de escolarização e de inclusão das narrativas documentais serão relacionadas com as experiências descritas por esses sujeitos em seus próprios relatos. No processo de inclusão é fundamental compreender a vivência dos estudantes surdos na escola regular inclusiva, uma vez que "a base da inclusão consiste no conceito de que toda pessoa tem o direito à educação e que esta deve levar em conta seus interesses, habilidades e necessidades de aprendizagem" (MIRANDA, 2012, p. 15).

As pesquisas sobre surdez na Bahia se configuram a partir dos artigos do Congresso Brasileiro de Educação Especial (CBEE), Congresso Baiano de Educação Inclusiva (CBEI), repositório de Trabalhos de Conclusão de Curso, em nível de graduação, da UNEB-Conceição do Coite, dissertações (mestrado acadêmico e profissional) e teses do repositório da Coordenação de Aperfeiçoamento de Pessoal de Nível Superior (CAPES). Isso demonstra que em vários âmbitos e locais existem pesquisadores interessados pela temática da surdez e seu entrelaço com a inclusão, principalmente com a presença de surdos narrando sobre si mesmos. No entanto, percebe-se que ainda é uma quantidade pequena em relação à historicidade do tema surdo no âmbito político-educacional e com isso, apesar dos ganhos legais e do percurso histórico, ainda há poucos trabalhos e estudos sobre a educação de 
surdos, nas quais os surdos estejam presentes.

As duas últimas décadas apresentam um cenário importante para os estudos da inclusão de surdos. O surgimento do CBEE, em 2003, ofertou à Educação Especial um lugar de destaque no âmbito da pesquisa científica em Educação em nível nacional, e contribuiu junto aos programas de pós-graduação para a ampliação de estudos e produções científicas na área da Educação Especial no Brasil. Dentre esses programas se destacou o Programa de Pós-Graduação em Educação Especial da Universidade Federal de São Carlos, que contribuiu (e anda contribui) para a formação de mestres e doutores em Educação Especial e se preocupou em abrir um espaço científico para a área, promovendo e organizando eventos a fim de atender à demanda emergente por novas práticas decorrentes das diretrizes educacionais de inclusão escolar no Brasil.

\section{CONCLUSÃO}

Tendo em vista que o texto apresentado, tratou-se e descreveu aspectos históricos da educação especial na Bahia (estado de origem das pesquisadoras e proponentes deste trabalho). Percebe-se que o século XX marcou historicamente o iniciar da trajetória da Educação Especial no Estado e reverberou e reverbera com sua presença através dos dados analisados, mas também da existências das instituições escolares, filantrópicas, e nos grupos de estudos e pesquisas, estes que têm ganhado novos sentidos de fazer pesquisa, pautando a inclusão, diversidade e acessibilidade. É importante também enfatizar que no atual século, vemos o emergir das pluralidades das pesquisas em inclusão, novas leis, outros contextos, tais como o pandêmico da Covid 19, não apenas nos desafia a um novo jeito de fazer pesquisa, congressos, eventos, mas de reexistir e existir diante das exclusões.

\section{PRINCIPAIS REFERÊNCIAS}

MATTOS, Nicoleta Mendes de. Inclusão e docência: a percepção dos professores sobre o medo e preconceito no cotidiano escolar. Tese de Doutorado. Universidade do Estado da Bahia: Salvador,2014.

MENDES, Enicéia Gonçalves. A radicalização do debate sobre inclusão escolar no Brasil. Rio de janeiro, Revista Brasileira de Educação, v. 11, n. 33, p. 387-405, set./dez. 2006.

MIRANDA, Theresinha Guimarães; FILHO, Teófilo Alves Galvão. O professor e a educação inclusiva: formação, práticas e lugares, Salvador: EDUFBA, 2012 


\section{TRIAGEM AUDITIVA ESCOLAR: UMA REVISÃO DE LITERATURA}

\section{Jamyle Rodrigues Luis ${ }^{1}$.}

${ }^{1}$ Graduada em Fonoaudiologia pela Universidade Federal de Sergipe, Campus Lagarto-SE.

\section{PALAVRAS-CHAVE: Audiologia. Educação. Fonoaudiologia.}

ÁREA TEMÁTICA: Inclusão educacional, dificuldades de aprendizagem e políticas públicas.

\section{INTRODUCÃ̃}

A audição é o primeiro sentido a ser desenvolvido ainda no período gestacional, estima-se que a parte estrutural da cóclea na orelha média está formada na $15^{\circ}$ semana de gestação e é anatomicamente funcional na $20^{\circ}$ semana gestacional (HALL,2020). Nesse momento os sons ambientais, externos já são capturados por esse sistema auditivo ainda em desenvolvimento. Um estudo realizado no hospital Albert Einstein com recém-nascidos demonstrou que as crianças preferem e acalmam-se com músicas ouvidas durante a gestação, evidenciando a importância de submeter a criança desde o período gestacional a estímulos sonoros. Acredita-se que as habilidades linguísticas começam a ser adquiridas na fase final da gestação, desse modo mães que conversam com o feto estariam habituando-o ao ritmo e a musicalidade da língua (Matias,1999,p.5). O desenvolvimento das diferentes habilidades auditivas depende da integridade do sistema auditivo ao nascimento e da experiência acústica no meio ambiente. Ao vivenciar sons verbais e não verbais a criança desenvolve suas habilidades auditivas, etapas constituintes do processamento auditivo. Desse modo, a integridade das vias auditivas consiste em um dos prerrequisitos para o desenvolvimento pleno das habilidades de linguagem oral, escrita e de leitura, uma vez que o sistema auditivo consiste em uma via de entrada de informações que posteriormente serão acessadas na fase de processamento das informações, sendo imprescindível no processo de ensino-aprendizagem. A população infantil é considerada mais propensa ao desenvolvimento de otites médias e nessa fase a recorrência de otites pode causar privações sensoriais momentâneas, o que pode causar alterações no desenvolvimento da linguagem e do aprendizado. Não existe dúvidas na literatura sobre as consequências da perda auditiva na infância e no impacto que a perda acarreta no desenvolvimento das habilidades de linguagem, fala, desempenho escolar e socialização. Crianças com deficiência auditiva não conseguem adquirir a linguagem no mesmo período e velocidade de uma criança que ouve bem, pois o aprendizado da linguagem é um evento essencialmente auditivo. Detectar a perda auditiva logo no início é fator primordial na minimização de danos na aprendizagem e vida social, sendo de suma importância a aplicação da triagem auditiva nos primeiros anos de vida e durante a vida escolar, uma vez que a perda auditiva pode ser adquirida, sendo então de suma importância manter os cuidados com a saúde auditiva durante todo o processo de desenvolvimento auditivo da criança. Estima-se que aproximadamente $80 \%$ das crianças em idade pré-escolar ou escolar podem sofrer de alguma perda auditiva temporária durante o ano letivo, ocasionando alterações na qualidade da audição. É também no período escolar que a perda auditiva 
se torna mais evidente, pois é a fase em que a criança inicia o seu processo formal de aprendizagem, devido a competição sonora nas salas de aula, essas crianças começam a apresentar dificuldade em compreender e acompanhar o conteúdo, sendo este, um dos principais responsáveis pelo fracasso escolar.

Nesse sentido, a triagem auditiva assume um importante papel no diagnóstico precoce de perda auditiva, possibilitando intervenção fonoaudiológica imediata, por se tratar de um processo de aplicação de testes rápidos e simples que pode ser realizado em um número grande de pessoas, não tendo a pretensão de diagnosticar, mas sim de identificar achados suspeitos que deverão ser encaminhados para a realização do diagnóstico e tratamento (NORTHERN E DOWNS,2005). A triagem auditiva deve fazer parte de um programa de saúde auditiva mais amplo que inclua os processos de prevenção primária, secundária e terciária. Nesse sentido, surgiu no Brasil a realização da Triagem Auditiva Neonatal (TAN), que tem por finalidade a identificação o mais precocemente possível da deficiência auditiva nos neonatos e lactentes. Consiste na aplicação de testes com medidas fisiológicas e eletrofisiológicas da audição, com o objetivo de identificar possíveis comprometimentos auditivos que deverão ser melhor avaliados por meio da avaliação audiológica completa. A TAN faz parte de um conjunto de ações que devem ser realizadas para a atenção integral à saúde auditiva na infância: triagem, monitoramento e acompanhamento do desenvolvimento da audição e da linguagem, diagnóstico e reabilitação. Sua realização é de suma importância para a detecção de possíveis perdas auditivas, contribuindo para um diagnóstico e intervenção precoce e evitando ou minimizando os danos que a perda auditiva pode causar na aprendizagem. Outrossim, os cuidados com a saúde auditiva devem permanecer durante toda a vida, levando em consideração que a deficiência auditiva também pode ser adquirida ao longo da vida, provocada por traumas e exposição ao ruído. Pensando nisso foi criada a Triagem Auditiva Escolar (TAE) que constitui em uma bateria de testes que podem ser padronizados ou comportamentais a depender do que o sujeito deseja encontrar na amostra selecionada. A realização da Triagem contribui para o diagnóstico precoce de perda auditiva, uma vez que serve de parâmetro na identificação de crianças que podem ter algum comprometimento auditivo, que devem então ser encaminhadas a realização da avaliação audiológica completa, quanto antes for comprovada a perda, mas chances essa criança terá de se alfabetizar sem grandes intercorrências. Sendo assim a TAE contribui para um melhor planejamento das ações educacionais que serão realizadas com essa criança e das adaptações que serão necessárias no espaço físico da sala de aula, conduzindo melhor esse aluno e proporcionando qualidade de acesso ao ensino. Desse modo, o presente trabalho tem por objetivo analisar por meio de uma revisão de literatura a realização da Triagem Auditiva no ambiente escolar.

\section{METODOLOGIA}

Trata-se de uma revisão de literatura realizada nas bases de dados do Scielo e Lilacs, sem período específico de publicação. Os artigos foram selecionados limitando-se a pesquisas realizadas com seres humanos nas línguas inglesa, portuguesa e espanhola, usando os descritores: Triagem auditiva escolar, Fonoaudiologia educacional e Audição Os artigos passaram por um processo de 
avaliação, onde em um primeiro momento foram analisados por meio de leitura exploratória do título e resumo dos trabalhos levando em consideração a relevância dos mesmos e o enquadre ao tema proposto. Em um segundo momento foram analisados por meio de leitura analítica, levando-se em consideração critérios preestabelecidos, sendo excluídas as revisões de literatura, teses, dissertações e estudos que fugiam do tema proposto. A amostra estudada foi composta por 25 artigos, que foram analisados levando em consideração a influência das seguintes variáveis: faixa etária da população estudada, procedimentos utilizados, região e prevalência de comprometimentos auditivos.

\section{RESULTADOS E DISCUSSÃO}

Os estudos demonstram que boa parte das pesquisas têm se concentrado nas regiões Sudeste (54\%), seguida das regiões Sul e Nordeste ambas representando 20\% dos estudos. Sendo estas regiões consideradas com o maio nível de predominância de perda auditiva na fase escolar, umas das pesquisas realizada no ano de 2010 demonstrou que a maior parcela de pessoas com deficiência auditiva está na Região Sudeste (42\%), seguida pelo Nordeste (42\%), seguida pelo Nordeste (26\%) e Sul (19\%). Já as regiões Centro-Oeste e Norte detêm os menores percentuais de surdos (6\% e 7\% respectivamente), o que pode justificar o maior interesse dessa população em promover pesquisas com essa temática. A faixa etária da população estudada se concentrou entre 3 à 12 anos, sendo esta fase crucial para o desenvolvimento de diversas habilidades que dependem da integridade das vias auditivas para se desenvolverem, como é o caso da linguagem oral, escrita e dos processos cognitivos de aprendizagem que dependem da devida interpretação dos códigos gráficos, sendo então de fundamental importância monitorar o desenvolvimento auditivo nesta fase. Os procedimentos mais utilizados na escola à fim de identificar possíveis danos à saúde auditiva foram: Inspeção do conduto auditivo interno, triagem do Processamento Auditivo central, Audiometria tonal e vocal, Imitanciometria e Emissões Otoacústicas. O que corrobora com o que preconiza o Plano Nacional de Saúde auditiva na escola que afirma que o procedimento de triagem de conter procedimentos comportamentais e eletrofisiológicos. Boa parte dos estudos concentraram-se na avaliação das vias auditivas centrais, tendo poucos estudos que tratem da avaliação de vias auditivas periféricas, o que pode ser justificado pelo custo alto dos aparelhos usados para este fim e da dificuldade em encontrar este serviço na rede pública. Os estudos evidenciam que o índice de falhas na realização da triagem gira em torno em torno de 13\%, sendo as alterações mais predominantes: presença de cerúmen, perda condutiva, seguida da perda neurossensorial, muitos apresentaram queixa de aparecimento de otites recorrentes durante o desenvolvimento da criança. Foi observado grande número de queixas relacionadas a aprendizagem nas populações com baixo rendimento escolar. O que demonstra a importância de manter programas de saúde auditiva nas escolas, pois quanto antes diagnosticada a perda, menores são os impactos sociais, emocionais e de aprendizagem nesta população. Um dado importante diz respeito ao grau de instrução da população com algum nível de deficiência auditiva, onde as pesquisas afirmam que cerca de $32 \%$ dessa população não têm nenhum grau de instrução na população em geral, esse número é de apenas $8 \%$. Programas de saúde auditiva que prezam por medidas de prevenção e promoção da saúde auditiva são de suma importância na diminuição destas disparidades, evitando anos de fracasso escolar e possibilitando mais oportunidades de emprego. Da 
mesma forma, entre os brasileiros portadores desse tipo de deficiência, só 7\% conseguem concluir o ensino superior, enquanto a média geral é o dobro: 14\%. Segundo relatos ouvidos durante a pesquisa, muitos surdos não conseguem concluir a graduação por causa da falta de intérpretes nas universidades, ou seja, a dificuldade inicia nas séries iniciais e continua durante toda a vida acadêmica do estudante.

\section{CONSIIDERAÇÕES FINAIS}

A deficiência auditiva constitui-se em um problema de saúde pública pois afeta a comunicação, o sucesso acadêmico e a qualidade de vida dos estudantes. A maioria dos casos de perda auditiva antes dos 15 anos é evitável e a detecção precoce pode ajudar a evitar atrasos acadêmicos e minimizar outras consequências. No Brasil estima-se que quase metade dos estados Brasileiros não realizam nenhum procedimento de monitoramento auditivo no ambiente escolar e entre aqueles que o realizam a quantidade é insuficiente e não abarca toda a população, o que deixa evidente as disparidades socioeconômicas e demográficas que assolam o nosso País. Sendo assim, é de fundamental importância a criação de programas nas escolas que prezem pela investigação de possíveis comprometimento de vias auditivas, promovendo a prevenção, promoção e reabilitação precoce, procedimentos que se realizados na idade certa diminuem demasiadamente os transtornos relacionados ao fracasso escolar, dificuldades sociais e emocionais que a perda auditiva pode causar.

\section{REFERÊNCIAS}

AZEVEDO, Marisa. Triagem Auditiva Neonatal. In: FERREIRA, L.; BEFI-LOPES, D.; LIMONGI, S. (org.). Tratado de Fonoaudiologia. São Paulo: Roca, 2004. p. 65-76.

AZEVEDO, Marisa; ANGRISANI, R. G. Desenvolvimento das Habilidades Auditivas. In: BOÉCHAT, E. M. et al. (Eds.). Tratado de Audiologia. 2. ed. Rio de Janeiro: Guanabara Koogan, 2015. p. 745750

LEWIS, Doris Ruthy et al. Comitê multiprofissional em saúde auditiva: COMUSA. Brazilian Journal of Otorhinolaryngology, v. 76, n. 1, p. 121-128, 2010.

LUDERS, Debora etal.Análise do perfilaudiométrico deescolares. Revista Distúrbios da comunicação Humana, São Paulo. 2015. Disponível em 16780-Texto do Artigo-57936-2-10-20150625 (1).pdf.

MATIAS, G.F. A importância da estimulação auditiva durante o período pré e pós-natal. Centro de especialização em Fonoaudiologia Clínica. Goiânia, p. 5-15, 1999.

TAMANINI, Daiane et al. Triagem auditiva escolar: identificação de alterações auditivas em crianças do primeiro ano do ensino fundamental. Revista CEFAC, Caxias do Sul, Set-Out; 17(5). Disponível em: https://www.scielo.br/j/rcefac/a/bxcC8tbQYzYLSWhMFy3LGPs/?lang=pt\&format=pdf. 


\author{
Naiane Rocha Mendes ${ }^{1}$. \\ ${ }^{1}$ Graduada em Letras, Língua Inglesa e Literaturas, UNEB, Jacobina, Bahia.
}

PALAVRAS-CHAVE: Inclusão Educacional. Comunicação Alternativa. Língua Inglesa.

ÁREA TEMÁTICA: Inclusão Educacional, dificuldades de aprendizagem e políticas públicas.

\title{
INTRODUÇÃO
}

Este trabalho relata a experiência formativa advinda do estágio de regência, planejado e aplicado como requisito da disciplina de Estágio Supervisionado III do curso de Letras, Língua Inglesa e Literaturas da Universidade do Estado (UNEB/DCHIV-Jacobina), no $2^{\circ}$ semestre de 2019, cujo objetivo foi assegurar a inclusão e a aprendizagem de Língua Inglesa por todos os alunos em contexto de sala de aula regular e especial, por meio da garantia de estratégias de mediação a partir do uso de Comunicação Alternativa. Deste modo, o foco principal esteve direcionado na utilização de conceitos de Comunicação Alternativa na elaboração de planos de aula e atividades voltadas ao ensino de Língua Inglesa, proporcionando espaços de diálogos e autonomia dos estudantes, respeitando as limitações e valorizando as potencialidades.

\section{METODOLOGIA}

O presente estudo baseia-se nos paradigmas da pesquisa-formação como procedimento metodológico com abordagem qualitativa. Segundo Perreli, et al. (2013) citando Nóvoa (2004), o conceito de pesquisa-formação se ancora:

[...] quando o formador forma a si próprio, mediante uma reflexão sobre os seus percursos pessoais e profissionais (autoformação); o formador forma-se na relação com os outros, numa aprendizagem conjunta que faz apelo à consciência, aos sentimentos e às emoções (heteroformação); o formador forma-se por meio das coisas (dos saberes, das técnicas, das culturas, das artes, das tecnologias) e da sua compreensão crítica (ecoformação). (NÓVOA, 2004, p.16 apud PERRELI, et al., 2013, p. 280) 
As disciplinas de estágios curriculares proporcionam esse espaço de diálogos de professor formador e reflexivo, instigando-nos a pensar sobre os processos que nos formam como professores, considerando o chão da escola e a diversidade da comunidade escolar.

O estágio foi autorizado e realizado em duas escolas públicas localizadas na cidade de Jacobina-Ba, no período de 01 de Outubro a 04 de Dezembro de 2019, com carga horária de quarenta (40) horas, sob orientação da Prof ${ }^{\mathrm{a}}$. Ma. Gracielia Novaes. Foi considerada como espaços de ensino e aprendizagens a sala regular do $8^{\circ}$ ano $\mathrm{C}$ do ensino fundamental II de uma escola estadual e a sala do Atendimento Educacional Especializado (AEE) de uma escola municipal. Participaram do estágio todos os alunos matriculados no $8^{\circ}$ ano $\mathrm{C}$ do colégio estadual e dois (2) alunos do ensino fundamental I e II matriculados tanto na sala de Atendimento Educacional Especializado (AEE) quanto na sala regular no colégio municipal. As aulas foram organizadas seguindo o planejamento regular das escolas, com dois (2) encontros semanais na escola estadual, totalizando 2 horas; e um (1) encontro semanal na sala do Atendimento Educacional Especializado (AEE), totalizando 3 horas.

\section{RESULTADOS E DISCUSSÕES}

Nesta seção, serão apresentados os resultados e discussões do estágio curricular aqui apresentado. Para melhor organização, serão elencadas duas seções a seguir:

\section{O ensino de Língua Inglesa no Atendimento Educacional Especializado (AEE)}

A Sala de Atendimento Educacional Especializado (AEE) ainda não havia sido pensada no curso de Letras, Língua Inglesa e Literaturas como um espaço possível para o desenvolvimento de estágios, em quaisquer que sejam os níveis, seja de observação ou regência. Contudo, foi solicitado via colegiado que tal proposta de estágio na sala do Atendimento Educacional Especializado (AEE) fosse considerada, levando em consideração que na sala especializada estão presentes alunos com necessidades educacionais especiais que estão matriculados na sala de aula regular e que necessitam de estratégias desenvolvidas no atendimento especializado para garantir a sua permanência na sala regular.

A sala especializada funciona como uma extensão da sala de aula regular e tem como função o atendimento educacional especial. Ressaltando que esses atendimentos devem acontecer, preferencialmente, na rede regular de ensino com o intuito de atender as peculiaridades dos alunos que, por diagnóstico clinico e/ou pedagógico, necessitam de um apoio especializado para garantir acesso e aprendizagem escolar.

O primeiro momento do estágio aconteceu com conversas informais com a professora regente da sala especializada, que explicou as necessidades dos alunos no que diz respeito a identificar e lidar com as emoções na sala regular. Segundo relatos da professora especializada, os professores da sala regular mencionavam que as principais dificuldades dos 2 (dois) alunos não estavam na aprendizagem dos conteúdos e sim na aceitação enquanto alunos com Necessidades Educacionais Especiais (NEE). Desta forma, foi pensado um planejamento com o tema diversidade associado ao lidar com as emoções 
dentro da diversidade, utilizando estratégias visuais e vocabulários em Língua Inglesa.

A regência foi dividida em três etapas: 1) Discussão do termo diversidade; 2) Como lidar com as emoções dentro da diversidade e, 3) Construção do livrinho das emoções. As discussões sobre o tema aconteciam de forma individual com os dois alunos que tinham disponível um horário préestabelecido para acompanhamento.

O Aluno $\mathrm{A}^{2}$, assim mencionado neste relato, apresentava sérios comprometimentos na fala, organização de espaço e compreensão das atividades escolares. Afirmava que estava gostando do tema, mas que seu ponto de interesse era desenhar e pintar. Diante da situação e dificuldade do aluno em ficar sentado ao conversar sobre diversidade e emoções de forma conceitual, utilizei como estratégia trabalhar com os personagens do filme Divertida Mente (2015), que representam as emoções em diferentes fases (alegria, medo, tristeza, nojo e raiva) e demos início a fase prática, de construção do livrinho das emoções.

No desenvolvimento do livrinho, o aluno A mostrou interesse nos cartões que representavam as emoções, mas que estavam escritos em Língua Inglesa. O objetivo de utilizar os cartões em inglês foi o de associar a imagem posta no cartão ao nome da emoção, gerando interpretação visual e aprendizagem da emoção, tanto na Língua Materna quanto na Língua Inglesa. O aluno era instigado a escolher a emoção que já havia sido ou que estava sendo vivenciada por ele e em seguida, o cartão era colado no livrinho e descrito com alguma história, ficcional ou pessoal, inventada ou vivenciada por ele.

A aluna $\mathrm{B}^{3}$ apresentava como principal dificuldade o processo de aceitação do diagnóstico de baixa visão, ainda recente. No desenvolvimento das etapas propostas, ela conseguia compreender as discussões e fazer uso de palavras em Língua Inglesa. Assim, no processo de construção do livrinho das emoções, a aluna optou por fazer uso dos cartões e escreveu histórias reais e ficcionais em português seguida da tradução em Língua Inglesa. Ao concluir a produção, a aluna B criou uma lista dos vocabulários aprendidos durante a construção da atividade e ao concluir a lista, foram percebidos avanços significativos na aprendizagem de Língua Inglesa.

2 Menino - oito anos - Diagnosticado com TDHA (Transtorno do déficit de atenção com hiperatividade).

3 Menina - Treze anos - Frequenta tanto a sala regular quanto o AEE - diagnosticada com baixa visão. 


\section{O ensino de Língua Inglesa na sala de aula regular inclusiva}

Ensinar uma Língua Estrangeira sempre foi desafiante, pois, fomos formados a pensar que seria impossível ensinar e aprender uma Língua Estrangeira na escola pública, principalmente a Língua Inglesa que se distancia da nossa Língua Materna, tanto em aspectos culturais quanto estruturais. Posto isto, nesse estágio de regência, fui instigada a trabalhar com as chamadas "classes inclusivas ou classes da inclusão". Numa turma com vinte e cinco alunos, 23 alunos eram ditos típicos, ou seja, estavam dentro dos padrões de normalidade postos pela sociedade atual e apenas dois desses alunos não se encaixavam em tais padrões, pois, os mesmos são surdos e segundo a escola, apresentavam sérios comprometimentos de aprendizagem, principalmente de Língua Inglesa.

Tendo como objetivo favorecer a inclusão e o ensino dos alunos, em diálogos e planejamentos construídos com a professora regente e a supervisora do estágio de regência, foi acordado que trabalharíamos com o tema inclusão, levando em consideração o uso da Língua Inglesa e da Comunicação Alternativa, instrumento este utilizado para favorecer e ampliar a comunicação de pessoas não oralizadas ou que necessitam de outras estratégias para ampliar as habilidades comunicativas, tais como: o uso de expressões faciais e corporais, imagens, gestos, Libras para o desenvolvimento efetivo de comunicação e interação social.

Assim sendo, optamos pelo trabalho colaborativo e dividimos a turma em pequenos grupos e fizemos debates e discussões a respeito do tema inclusão, fazendo uso de vocabulários em Língua Inglesa. Após as discussões, foram trabalhadas produções textuais escritas, com imagens seguidas de legendas em Libras, favorecendo a compreensão dos estudantes com surdez. A partir das produções escritas, foram gravados vídeos sobre a temática da inclusão educacional, produções que refletiram a aprendizagem dos alunos na Língua Inglesa e, principalmente, como sujeitos diversos e sociais.

\section{CONSIDERAÇÕES FINAIS}

No contexto escolar atual é de fundamental importância refletir sobre os processos de inclusão educacional e os moldes de ensino propostos para o desenvolvimento da aprendizagem dos sujeitos. Pensar nas chamadas "classes inclusivas" e "alunos da inclusão" pode ocasionar a exclusão de estudantes típicos que necessitam de um acolhimento educacional mais atento, logo, é de extrema importância pensarmos o ambiente escolar como diverso e potente, compreendendo que a educação precisa ser inclusiva para todos os sujeitos e que a inclusão é um tema interdisciplinar, podendo ser trabalhado por todos os professores e em disciplinas diversas.

A comunicação é uma habilidade essencial para que haja interação e inclusão dos sujeitos nas relações sociais. Durante o processo aquisitivo da linguagem das crianças é perceptível a evolução de diversas formas de comunicação, tais como: gritos, gestos, sílabas iniciais ou finais para expressar uma palavra ou ação, movimentos (DELIBERATO, 2017). Assim, levando em consideração a amplitude e a complexidade das relações comunicacionais, tivemos o cuidado de planejar aulas que estimulassem outras formas de se comunicar dos estudantes, pensando a Comunicação Alternativa como potência para o desenvolvimento comunicativo de todos os estudantes, com ou sem deficiência. 
A Comunicação Alternativa não é exclusiva para o uso da pessoa com Necessidades Educacionais Especiais (NEE), podendo contribuir com eficácia na aprendizagem de todos os alunos em contextos de sala de aula regular. Para concluir, saliento que precisamos ressignificar os conceitos de língua e ensino de língua, compreendendo comunicação para além da fala e a formação de professores de língua para além da língua - pautada na formação social e educacional para atuar na diversidade.

\section{PRINCIPAIS REFERÊNCIAS}

DELIBERATO, Débora. Comunicação Alternativa na Educação Infantil: Instrumentos para Aquisição de Competências do Aluno com Deficiência. In: Trilhando Juntos a Comunicação Alternativa. São Paulo: Associação Brasileira de Pesquisadores em Educação Especial, 2017, p. 7795.

DIVERTIDA MENTE. Direção: Pete Docter. Produção: Pixar Animation Studios. Disney. 23 de Setembro de 2019. 102min. Disponível em: https://www.disneyplus.com/pt-br . Acesso em: 17 de setembro de 2021.

PERRELI, M.A.S; FLAVINÊS, R; TEIXEIRA, L.R.M; NOGUEIRA, E,G,D. Percursos de um grupo de pesquisa-formação: Tensões e reconstruções. Brasília: Estudos RBEP, 2013. 


\title{
RESUMO EXPANDIDO
}

\author{
INCLUSÃO NO ENSINO DAS CIÊNCIAS \\ (MATEMÁTICA, FÍSICA, QUÍMICA E BIOLOGIA)
}




\title{
Gabriela Dutra Rodrigues Conrado'.
}

\author{
${ }^{1}$ Mestrado em Educação Matemática, IFPB, Sousa, Paraíba.
}

PALAVRAS-CHAVE: Desenho Universal da Aprendizagem. Teorema de Pitágoras. Materiais manipuláveis.

ÁREA TEMÁTICA: Inclusão no ensino das Ciências (matemática, física, química e biologia).

\section{INTRODUÇÃO}

As questões sobre a Educação Inclusiva fazem parte dos desafios na atuação dos professores em suas salas de aula. A partir da lei 13.146 de 06 de julho de 2015, que além de assegurar o direito de estudantes com deficiência a frequentar o ensino regular estabelece a garantia de condições de igualdade ao conhecimento e ao desenvolvimento individual dos sujeitos, novos grupos e perfis de alunos vem compondo os espaços escolares. Esse cenário educacional caracteriza-se, entre outros aspectos, pela presença da diferença dentro da escola.

No que tange a atuação dos professores, propiciar um ambiente diverso em que cada aluno e cada aluna possam ter respeitadas e valorizadas suas singularidades, sendo estudantes com ou sem deficiência, é um dos grandes desafios atualmente. Nesse sentido, o Desenho Universal da Aprendizagem (DUA) pode colaborar para um ambiente escolar inclusivo em que todos e todas possam desenvolverem-se de acordo com suas potencialidades. O DUAé uma proposta de organização das estruturas educacionais que permitem o acesso de todo e qualquer sujeito com a eliminação ou diminuição de barreiras de acesso ao conhecimento e ao espaço escolar (BOCK et al, 2018).

Seguindo pressupostos do DUA elaborou-se material manipulável de apoio para o ensino do Teorema de Pitágoras a ser utilizado duas turmas de $9^{\circ}$ ano de Ensino Fundamental em uma escola pública municipal no Rio Grande do Sul, as quais tinham alunos com deficiência. Muitas vezes os estudantes percebem a Matemática como uma disciplina demasiadamente abstrata, na qual predominam as práticas de operações numéricas e algébricas. Nesse sentido, o uso de materiais manipuláveis pode ampliar as visões dos estudantes sobre a própria Matemática e sobre sua aprendizagem (LORENZATO, 2012). O propósito pedagógico do material relatado nesse texto foi superar barreiras e possibilitar experiência de educação inclusiva na Matemática proporcionando experimentações matemáticas em que todos os estudantes pudessem comprovar a equivalência de áreas no triângulo retângulo independentemente das limitações impostas pelas deficiências de alguns desses alunos. Em resumo o objetivo era criar um material e encaminhamento didático inclusivo para o ensino desses conceitos matemáticos. Assim, nesse texto relata-se a experiência vivenciada no ensino do Teorema de Pitágoras. Na sequência do texto apresenta-se Metodologia e posteriormente 
as Discussões seguidas das Considerações Finais.

\section{METODOLOGIA}

Esse texto relata a experiência da autora ocorrida no segundo semestre letivo de 2019 para o ensino do Teorema de Pitágoras para estudantes de duas turmas do $9^{\circ}$ ano do Ensino Fundamental em uma escola municipal no interior do RS. A turma A9A contava com vinte e sete estudantes sendo dois deles alunos com deficiências, um com diagnóstico de síndrome de Williams (dificuldades de coordenação, equilíbrio e atraso psicomotor) e outro com tetraparesia (perda parcial de todos os membros) ocasionada por uma doença degenerativa. A turma A9A, apesar de agitada, sempre foi participativa e interessada. Na turma A9B, com vinte estudantes, o contexto era um pouco diferente, os alunos nem sempre se mostram empenhados em realizar as atividades. Nessa turma, havia um aluno com autismo, cujas condições limitavam parcialmente sua participação em aula e uma aluna com déficit de atenção, que acompanhava as atividades com raras necessidades de adaptação.

No ensino do Teorema de Pitágoras é usual que professores façam uso de estratégias para demonstrar que o quadrado da hipotenusa é igual a soma dos quadrados dos catetos. Muitas dessas estratégias envolvem materiais manipulativos que são construídos com papel, tesoura e régua, os quais precisam de precisão para manuseio. Devido as limitações dos estudantes foi elaborado um material que pudesse ser utilizado por qualquer estudante sem perda dos objetivos pedagógicos de experimentação, descoberta e sistematização do conhecimento matemático. O material consiste em triângulos de medidas $3 \mathrm{~cm}, 4 \mathrm{~cm}, 5 \mathrm{~cm}$ e $6 \mathrm{~cm}, 8 \mathrm{~cm}, 10 \mathrm{~cm} 3 \mathrm{~cm}, 4 \mathrm{~cm}, 5 \mathrm{~cm}$ e $6 \mathrm{~cm}, 8 \mathrm{~cm}, 10 \mathrm{~cm}$ e malhas quadriculadas quadradas com essas mesmas medidas de lado, além de dezenas de quadrados unitários de $1 \mathrm{~cm} .1 \mathrm{~cm}$. Todos construídos com material resistente e de cores contrastantes, conforme mostram as três figuras a seguir.

Figura 1, 2 e 3 - Material manipulável para estudo do Teorema de Pitágoras
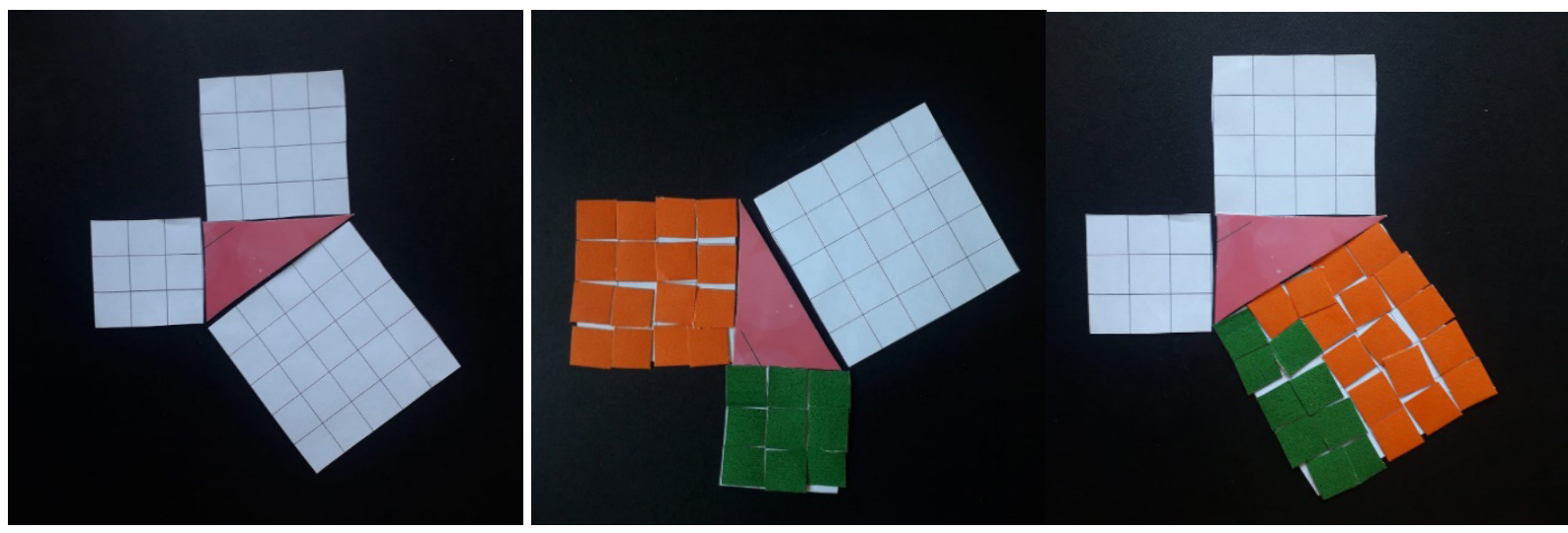

Fonte: arquivos da autora 
Após o detalhamento do contexto motivador para elaboração do material e explicação do material manipulável construído, compartilha-se aspectos da experiência docente com o uso do material.

\section{DISCUSSÕES}

Considerando as diferenças e particularidades das turmas em que a atividade foi realizada iniciou-se realizando uma revisão sobre caraterísticas sobre triângulo quando ao tamanho de seus lados e ângulos internos, apresentando diferentes tipos de triângulos em material manipulável aos estudantes. Seguiu-se, com uso do software GeoGebra, apresentando a representação geométrica dos quadrados perfeitos, para que os estudantes pudessem se familiarizar com os objetos e tipos de linguagem do material manipulável construído para o ensino do Teorema de Pitágoras. Esses dois primeiros momentos tiveram duração de dois períodos letivos e contaram com a participação dos estudantes de maneira ampla.

Posteriormente, o material manipulável foi distribuído para todos os alunos e alunas, que estavam organizados em trios, a fim de que manuseassem e pudessem conhecer os objetos. Foi solicitado compor os triângulos com seus quadrados da malha quadriculada e preencher com os quadrados pequenos apenas os quadrados dos catetos. Após, orientou-se os estudantes a verificar a equivalência das áreas, fazendo experiências com triângulos de tamanhos diferentes. Evoluindo para a construção da formalização do Teorema de Pitágoras.

É importante destacar que além dos estudantes com deficiência conseguirem realizar as experiências e levantamento de hipóteses os outros estudantes conseguiram participar de maneira igualitária nas manipulações, além de visivelmente estarem confortáveis em presenciar os colegas com deficiência participando das atividades. Esse comportamento foi observado principalmente na turma A9A, na qual os alunos com deficiência encontram um ambiente de muito acolhimento em sala de aula por parte se seus colegas.

\section{CONSIIDERAÇÕES FINAIS}

Este texto relata a experiência no uso de materiais manipuláveis na perspectiva DUA para o ensino do Teorema de Pitágoras. A participação de todos os alunos e alunas tanto na manipulação quando nos debates realizados mostram que conseguiu-se minimizar limitações oferecendo uma experiência de aprendizagem universal para as duas turmas.

Cabe destacar que o material utilizado é bastante simples e não necessitou elaboração ou criação rebuscada por parte da professora. Teve como foco superar barreiras e possibilitar experiência de educação inclusiva na Matemática. Nas observações durante as manipulações dos estudantes verificou-se a necessidade de elaborar triângulos em que a malha quadriculada tenha tamanho maior, pois um dos alunos teve dificuldade em manusear os quadrados unitários de $1 \mathrm{~cm}, 1 \mathrm{~cm}$, acredita-se que o dobro desse tamanho consiga atender as necessidades de estudantes com maiores dificuldades motoras. 


\section{REFERÊNCIAS}

LORENZATO, Sérgio. O Laboratório de Ensino de Matemática na Formação de Professores. Campinas-SP, Autores Associados. 3. ed. 2012.

BOCK, Geisa Letícia Kempfer; GESSER, Marivete; NUERNBERG, Adriano Henrique. Desenho Universal para a Aprendizagem: a Produção Científica no Período de 2011 a 2016. Revista Brasileira de Educação Especial, v. 24, n. 1, p. 143-160, 2018. 
Naiara Silva Menezes'; Luiza Dórea de Santana Silva²; Viviane Borges Dias ${ }^{3}$.

${ }^{1}$ Licencianda em Ciências Biológicas, UESC, Ilhéus, Bahia.

${ }^{2}$ Licencianda em Ciências Biológicas, UESC, Ilhéus, Bahia.

${ }^{3}$ Professora Adjunta do Departamento de Ciências Biológicas, UESC, Ilhéus, Bahia.

PALAVRAS-CHAVE: Educação inclusiva. Autismo. Ensino de Ciências.

ÁREA TEMÁTICA: Inclusão no ensino das Ciências (matemática, física, química e biologia).

\section{INTRODUCÃ̃O}

No Brasil, os dados do Censo Escolar da Educação Básica indicam que em 2019, ocorreu um aumento de 92,8\% no número de matrículas de alunos de 4 a 17 anos, com deficiências e transtornos globais do desenvolvimento, como o Transtorno do Espectro Autista (TEA), em classes comuns (INEP, 2020).

Apesar desse cenário, algumas pesquisas, como a de Rocha-Oliveira, Machado e Siqueira (2017) têm destacado que ainda é difícil encontrar trabalhos que articulem a formação de professores com a Educação Inclusiva. Nesse sentido, é importante que essa discussão esteja presente nos cursos de formação de professores, pois "os fundamentos da Educação Inclusiva passam, entre outros aspectos, por uma formação docente capaz de considerar as diferenças dos alunos e suas aprendizagens” (DIAS; SILVA, 2020, p. 410).

Relacionado à formação de professores, o curso de Licenciatura em Ciências Biológicas de uma universidade pública do sul da Bahia, oferece uma disciplina chamada Educação Inclusiva para o Ensino de Ciências e Biologia, com carga horária de sessenta horas, na modalidade optativa. No entanto, o Projeto Pedagógico Curricular do referido curso passou por reformulação e essa disciplina será ofertada como obrigatória, o que indica um avanço, tendo em vista a formação de professores que tenham como foco as discussões sobre Educação Inclusiva.

No decorrer da referida disciplina, foi desenvolvida uma atividade como forma de avaliação, na qual tínhamos que elaborar uma proposta de material didático ou aula para o ensino de Ciências e Biologia, adaptada para alunos com deficiências ou transtornos de desenvolvimento. Assim, nossa proposta foi idealizada para alunos com TEA.

De acordo com o Manual Diagnóstico e Estatístico dos Transtornos Mentais (DSM), em sua versão mais recente (DSM - 5), publicada no ano de 2013, o TEA, é um transtorno do neurodesenvolvimento caracterizado por déficits persistentes na comunicação social e na interação social. Além disso, apresenta padrões restritos e repetitivos de comportamento, interesses ou atividades 
(APA, 2014).

Diante do exposto, esse trabalho tem por objetivo apresentar um relato de experiência referente a uma atividade adaptada para alunos com TEA, desenvolvida na disciplina de Educação Inclusiva para o ensino de Ciências e Biologia.

\section{METODOLOGIA}

A proposta de aula prática foi desenvolvida no curso de Licenciatura em Ciências Biológicas de uma universidade pública do sul da Bahia, na disciplina de Educação Inclusiva para o ensino de Ciências e Biologia, como forma de atividade avaliativa. Assim, a atividade precisava ser pensada para aplicação no contexto do ensino remoto para alunos com deficiência ou transtorno de desenvolvimento, uma vez que estamos passando por uma pandemia e as aulas estão acontecendo remotamente.

Nesse sentido, a aula prática foi estruturada para uma turma de $7^{\circ}$ ano do ensino fundamental II, utilizando o tema fungos, adaptada para alunos com TEA, objetivando relacionar a temática fungos com o cotidiano dos estudantes. Nessa perspectiva, partindo da condição que os alunos já tinham conhecimento sobre a temática abordada, foi elaborado um roteiro da aula, com o material que seria utilizado para realização da aula prática, que seria enviado para os alunos na semana anterior. $\mathrm{O}$ material utilizado para realizar o experimento é de baixo custo e de fácil aquisição: duas garrafas pet, fermento biológico, açúcar, balão de festa e água morna.

O primeiro momento da aula seria uma revisão sobre os tipos e as características de fungos. Posteriormente, seria feita a explicação e realização do experimento seguindo os seguintes passos:

- Em uma garrafa pet colocar água morna, fermento e açúcar;

- Na outra garrafa, colocar água morna e fermento;

- Misturar até dissolver o conteúdo presente nas garrafas;

- Prender um balão de festa na abertura de cada garrafa;

- Observar o que acontece em cada recipiente.

Em seguida seria aplicada uma atividade, na qual os alunos descreveriam passo a passo do experimento e o que ocorreu. Depois, seria disponibilizado um material de apoio com revisão.

\section{RESULTADOS E DISCUSSÕES}

A construção dessa proposta de aula prática foi pensada para inclusão de um aluno com TEA, de grau leve, alfabetizado, verbal, com dificuldade de mudanças de rotinas e de socialização, com hiper foco em desenhos. Vale ressaltar, que para pensar atividades que visem à inclusão dos alunos com TEA é importante conhecermos as especificidades desses alunos, levando em consideração todos os interesses, os estressores, e as dificuldades que esse estudante tenha no processo de ensino e aprendizagem. 
Considerando o exposto, no momento da realização do experimento (Figura 1B) proposto seria feita uma contextualização com o cotidiano, com o objetivo de conhecer o papel dos fungos na fermentação, utilizado para a produção de alimentos, como a fabricação de pães, trazendo aspectos do ensino por investigação, através de questionamentos tais como: "o que você acha que irá acontecer com o experimento?" "Por que na mistura que tinha fermento, água morna e açúcar a bola encheu e o que tinha apenas água e fermento não encheu?" “Qual o gás que inflou o balão?”. Estas perguntas têm a intenção de envolver o aluno na aula, favorecendo a aprendizagem, a interação e a comunicação.

De acordo com Alves (2016), a utilização de atividades práticas caracteriza-se como uma metodologia interessante para envolver o aluno com TEA nas aulas de Ciências e Biologia, visto que aproxima o aluno da vivência cotidiana.

Outro ponto que vale destacar é a produção do roteiro da aula (Figura 1A) com os materiais que utilizaríamos, esse roteiro foi elaborado com pouco texto e com suporte visual (utilização de imagens para ajudar na leitura do texto), o qual seria enviado para o estudante com antecedência, visto que o aluno tem dificuldades com mudanças de rotina. Ademais, preparamos um material de revisão (Figura 1C), que também foi feito com utilização de textos curtos e imagens.

Figura 1: A- Roteiro da aula; B- Resultado do experimento C- Página 2 do material de apoio com revisão.
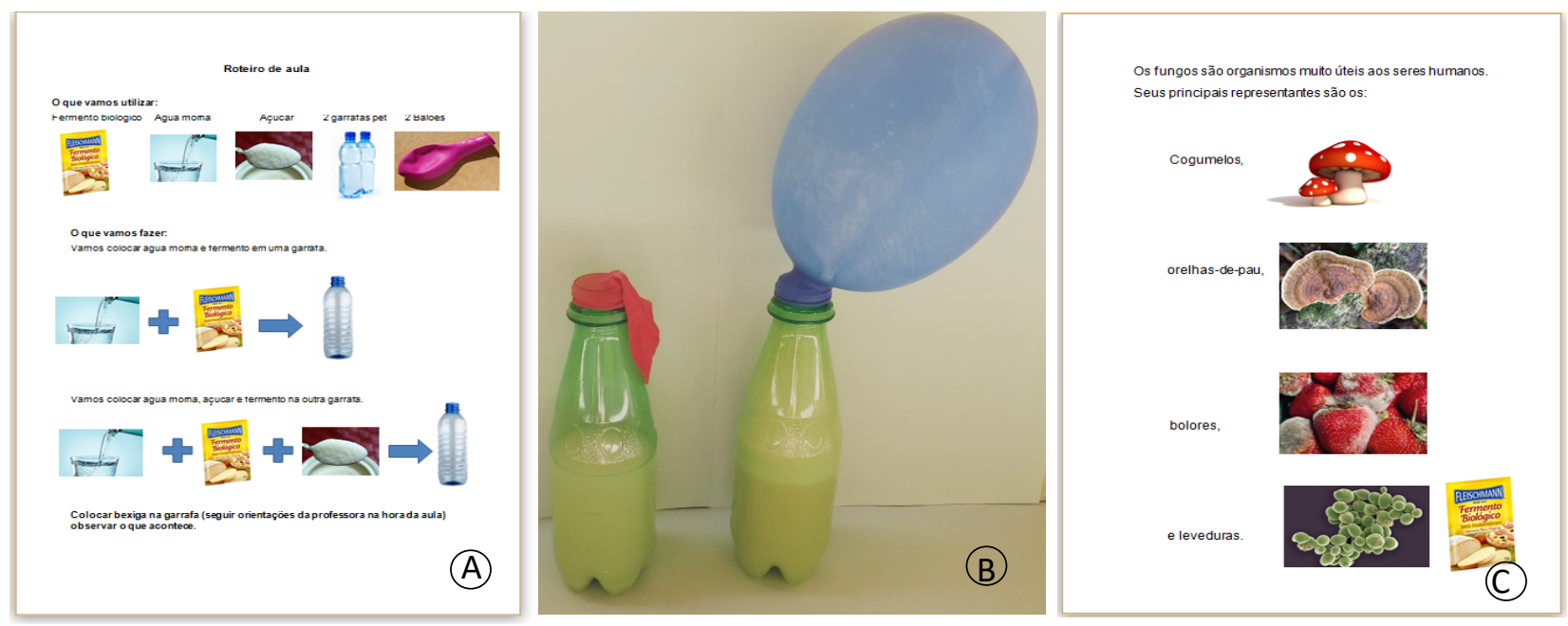

Fonte: arquivo pessoal, 2021.

Em relação a utilização de imagens como estratégia didática para estudantes com TEA, Benini e Castanha (2016) apontam que as figuras colaboram na organização do pensamento e da linguagem, aprimorando a aprendizagem desses alunos. 


\section{CONCLUSÃO}

A disciplina de Educação Inclusiva para o ensino de Ciências e Biologia e a atividade que desenvolvemos contribuiu para nossa formação inicial, através de discussões fundamentais e de grande relevância, relacionadas à inclusão de alunos com deficiência no ensino regular, visto que o número de matrícula desses estudantes vem aumentando.

Ademais, colaborou para compreendermos que não devemos nem podemos resumir as pessoas à sua deficiência ou transtorno. No entanto, é importante entendermos sobre as especificidades de cada discente, a fim de oferecer uma educação de qualidade e inclusiva, favorecendo o ensino e aprendizagem.

\section{PRINCIPAIS REFERÊNCIAS}

ALVES, L. B. Estratégias Metodológicas no Ensino de Ciências e Biologia para alunos com diagnóstico de autismo. TCC (Licenciatura em Biologia) - Universidade Federal do Recôncavo da Bahia, Cruz das Almas - BA, 2016. Disponível em: http://www.repositoriodigital.ufrb.edu.br/ bitstream/123456789/1188/1/Monografia\%20Luziane.pdf. Acesso em: 17 de maio de 2021.

APA. Manual diagnóstico e estatístico de transtornos mentais: DSM-5 / American Psychiatric Association - 5. ed. - Porto Alegre: Artmed, 2014. Disponível em: https://www.researchgate.net/ publication/284455957_Manual_Diagnostico_e_Estatistico_de_Transtornos_Mentais_-_DSM-5_ estatisticas_e_ciencias_humanas_inflexoes_sobre_normalizacoes_e_normatizacoes Acesso em: 20 abr. 2021.

BENINI, W.; CASTANHA, A.P.; BENINI, W. C. A inclusão do aluno com transtorno do espectro autista na escola comum: desafios e possibilidades. Cadernos PDE, Paraná, v. 1, 2016.Disponível em: http://www.diaadiaeducacao.pr.gov.br/portals/cadernospde/pdebusca/producoes_pde/2016/2016_ artigo_ped_unioeste_wivianebenini.pdf Acesso em: 07 jun. 2021.

DIAS, V. B; SILVIA, L. M. da. EDUCAÇÃO INCLUSIVA E FORMAÇÃO DE PROFESSORES: O QUE REVELAM OS CURRÍCULOS DOS CURSOS DE LICENCIATURA?

Revista Práxis Educacional, Vitória da Conquista - Bahia - Brasil, v. 16, n. 43, p. 406-429, Edição Especial, 2020. Disponível em: https://doi.org/10.22481/rpe.v16i43.6822 Acesso em: 04 ago. 2021.

INEP. Instituto Nacional de Estudos ePesquisas Educacionais Anísio Teixeira. Notas Estatísticas. Censo Escolar 2019. Ministério da Educação. Brasília-DF |Janeiro 2020. Disponível em: $<$ http://download. inep.gov.br/educacao_basica/censo_escolar/notas_estatisticas/2017/notas_estatisticas_censo_ escolar_da_educacao_basica_2017.pdf $>$. Acesso em 15 abr. 2021.

ROCHA-OLIVEIRA, R.; MACHADO, M. S.; SIQUEIRA, M. Formamos professores para a educação inclusiva? Análise de publicações sobre formação de professores de Ciências/ Biologia. Revista Brasileira de Ensino de Ciência e Tecnologia, 10(2), p. 1-23, 2017. Disponível em: https:// doi. org/10.3895/rbect. v10n2.3784. Acesso em: 02 abr. 2021. 


\section{Luiza Dórea de Santana Silva ${ }^{1}$; Naiara Silva Menezes²; Viviane Borges Dias ${ }^{3}$.}

${ }^{1}$ Licencianda em Ciências Biológicas, Universidade Estadual de Santa Cruz (UESC), Ilhéus, Bahia. ${ }^{2}$ Licencianda em Ciências Biológicas, Universidade Estadual de Santa Cruz (UESC), Ilhéus, Bahia. ${ }^{3}$ Professora Adjunta do Departamento de Ciências Biológicas, Universidade Estadual de Santa Cruz (UESC), Ilhéus, Bahia.

PALAVRAS-CHAVE: Educação inclusiva. Mitose. Stop Motion.

ÁREA TEMÁTICA: Inclusão no ensino das Ciências (matemática, física, química e biologia).

\section{INTRODUÇÃO}

A Pandemia da Covid 19 trouxe consigo uma série de mudanças na forma de ensino até então adotada. $\mathrm{O}$ ensino remoto então em voga atualmente, envolve desafios diários e exige tanto de docentes como dos discentes algumas "competências tecnológicas e recursos materiais como acesso à internet e equipamentos de qualidade" (LEITE ET AL, 2020, p.03).

Pensando nesse contexto e as suas implicações para alunos com deficiência visual, é notório que as Tecnologias da Informação e Comunicação (TICs) se configuram como uma alternativa viável para esses estudantes que já possuem uma certa familiaridade com o ambiente virtual e utilizam de softwares de acessibilidade que permitem a leitura de tela e síntese de voz como o Dosvox, o Jaws, o NVDA e o Virtual Vision, além de equipamentos como a Linha ou Display em Braille (SONZA; SANTAROSA, 2003).

Diante do exposto, a pergunta que se faz é: Como ensinar conteúdos de Ciências/Biologia para alunos com deficiência visual tendo em vista o contexto de aula virtual? Em síntese o ensino de Ciências é muito marcado pela presença de conceitos e processos abstratos, de difícil visualização e, pensando ainda nas implicações do ensino remoto em decorrência da situação pandêmica a qual nossa sociedade está imersa, a compreensão de certos conteúdos por parte dos alunos torna-se ainda mais difícil.

Sendo assim, além do professor precisar procurar alternativas diferentes e criativas para se trabalhar conteúdos de Ciências e Biologia com seus alunos é necessário que este docente pense também em possibilidades que tornem esse material inclusivo.

O presente trabalho, portanto, foi desenvolvido como componente curricular da disciplina de Educação Inclusiva para o ensino de Ciências e Biologia, e objetiva trazer uma proposta de material didático adaptado sobre a temática de divisão celular, mais especificamente acerca da apresentação do processo de mitose para alunos com deficiência visual no contexto do ensino remoto. Para isto, dois 
materiais foram produzidos, um slide e um Stop Motion $_{1}$.

\section{METODOLOGIA}

A pesquisa segue uma abordagem qualitativa de caráter exploratório. Segundo Chizzotti (2017, p.98), nesse tipo de pesquisa “[...] há uma relação dinâmica entre o mundo real e o sujeito, uma interdependência viva entre o sujeito e o objeto, um vínculo indissociável entre o mundo objetivo e a subjetividade do sujeito".

Este trabalho foi desenvolvido como componente curricular da disciplina de Educação Inclusiva para o Ensino de Ciências e Biologia, que tinha por escopo a elaboração e apresentação de uma proposta de material didático adaptado para alunos com uma dada deficiência, e por meio desse material viesse a ser trabalhado algum conteúdo de Ciências e/ou Biologia no contexto do ensino remoto.

Por este motivo, o público escolhido foram alunos do $9^{\circ}$ ano do Ensino Fundamental II com deficiência visual - baixa visão e cegueira - e tomando como base as características de cada uma delas de modo que esses alunos pudessem acessar os ambientes virtuais e arquivos digitais utilizados no ensino remoto. Nessa perspectiva, foi possível pensar em ferramentas que pudessem contribuir para o aprendizado desses alunos mesmo nas atuais circunstâncias.

Sendo assim, o assunto escolhido para ser trabalhado foi à divisão celular, mais especificamente o processo de Mitose. Os conteúdos atrelados a esse tema que seriam explanados versam sobre o conceito de Mitose, a sua importância, as suas fases e as características de cada uma dessas fases. Para isso, foram propostos dois materiais didáticos que atuariam de maneira conjunta e de forma complementar. O primeiro seria um arquivo digital em slide e o segundo um Stop Motion.

O slide elaborado teve por objetivo servir como um material de estudo que reúne todo o conteúdo acima mencionado. Esse material foi pensado para ser entregue previamente para os alunos, no contexto de uma aula assíncrona, a fim de que eles pudessem fazer uma leitura prévia e se apropriar dos principais conceitos e informações e, posteriormente também ser trabalhado no contexto de uma aula síncrona pelo Google Meet por meio da mediação do professor.

Para a elaboração desse slide para alunos com cegueira, tendo em vista o ensino remoto, é necessário que esse material não disponha de muito texto, apresente títulos em cada página de modo que o conteúdo seja delimitado, a fim de torná-lo mais claro quando submetido à utilização de softwares e que o assunto se dê de forma concisa e com linguagem de fácil entendimento.

Os softwares utilizados para pessoas com cegueira permitem de forma mais geral a leitura de tela. Como exemplos, temos o Dosvox, o Virtual Vision, o NVDA e o Jaws que convertem toda a informação textual da tela do computador em voz. Mas, o ambiente virtual assim como os arquivos digitais a exemplo do slide descrito nesse trabalho, pode ser acessado pelas pessoas cegas por meio da utilização de equipamentos como a Linha/Display em Braille onde o conteúdo textual passa a ser convertido em informação tátil.

Pensando na elaboração do slide para pessoas com baixa visão, esse material deve possuir adaptações na própria formatação do texto, por meio do uso de fontes adequadas e, sem serifa. Como por exemplo, a Arial e a Verdana de tamanho preferencialmente 24, em negrito e em bastão 
(maiúscula). Outro ponto importante é utilizar espaçamento em linha dupla, cores em destaque e fundo claro. Se esse aluno ainda dispuser de recursos ópticos como lupas e lentes de aumento e/ou softwares que possibilitam a ampliação de tela, torna-se o acesso a esse material ainda mais viável.

Em relação à produção do Stop Motion, ele foi pensado para se trabalhar de forma mais prática e dinâmica a parte das fases e características de cada fase da Mitose. Para sua confecção foi preciso massinha de modelar para compor os elementos, uma cartolina branca para o fundo e também de um aplicativo para celular chamado Stop Motion Studio.

Pensando na necessidade de adaptação de recursos audiovisuais, amplamente utilizados no contexto de ensino remoto, foi utilizada a técnica de audiodescrição que se caracteriza pela transposição do signo visual em signo verbal, através de uma descrição objetiva de imagens que permite a compreensão integral da narrativa audiovisual (LIMA, 2016). Além da audiodescrição, também foi adicionado legenda no Stop Motion ${ }_{2}$, a fim de tornar esse material ainda mais inclusivo.

\section{FUNDAMENTAÇÃO TEÓRICA}

A deficiência visual é uma expressão que se refere a um espectro que abrange desde a visão subnormal até a cegueira. Essas duas categorias são definidas a partir de dois valores quantitativos, a acuidade visual, que diz respeito a tudo aquilo que se enxerga a uma determinada distância, e o campo visual, que diz respeito à amplitude da área alcançada pela visão (CONDE, 2017).

A baixa visão ou também conhecida como visão subnormal é uma alteração da capacidade visual decorrentes de fatores como o rebaixamento significativo da acuidade e campo visual (GIL, 2000). A cegueira por sua vez pressupõe a perda completa da visão, e pode ser congênita (advém desde o nascimento), ou adquirida (onde o indivíduo nasce com o sentido, mas vai perdendo com o passar do tempo) (ALMEIDA E ARAÚJO, 2013).

Pensando na elaboração de materiais didáticos para o ensino de Ciências no contexto do ensino remoto, e consequentemente no processo de inclusão das pessoas com deficiência visual, é importante que este material além de estimular os demais sentidos do indivíduo em questão, seja um material que possibilite a apresentação do conteúdo de forma dinâmica, para chamar a atenção do aluno.

De acordo com Corrêa et al (2020, p.03) uma boa ferramenta para se trabalhar na realidade do ensino remoto, são os recursos audiovisuais, pois "mostram-se como alternativa atual e amplamente empregada [...] como ferramenta didática em sala de aula, [...] A aplicação de atividades e/ou materiais pedagógicos que utilizam imagens e sons facilita a demonstração de conteúdos”.

Por esse motivo, o Stop Motion que é um recurso audiovisual, é uma ferramenta completa que possibilita empregar processos biológicos de forma detalhada e também cativar os alunos por meio de sua dinamicidade. De acordo com Neco e Rocha (2018), o Stop Motion pode ser uma ferramenta que vai além do cinema, mas servir também como ferramenta didática para o ensino de temas complexos da ciência.

Para adaptar esse material para alunos com deficiência visual é necessário utilizar da audiodescrição, que, é uma "modalidade de tradução audiovisual [...] que visa tornar acessíveis 
produtos e atividades culturais de comunicação e de informação a pessoas com deficiência. [...] tem como público primário as pessoas com deficiência visual, [...] mas pode ser útil para as pessoas com deficiência intelectual, autistas e [...] idosos (CARNEIRO, 2020).

\section{CONCLUSÃO}

O presente trabalho pôde demonstrar que é possível inovar dentro do ensino de Ciências durante a vigência do ensino remoto, de maneira criativa e trazendo a ludicidade para a sala de aula, a fim de despertar nos alunos o interesse para com assuntos complexos como a Mitose por meio da aplicação de um recurso audiovisual que foi o Stop Motion. Além disso, mostra que é possível tornar esse material inclusivo através de pequenas adaptações como a adição de legenda e audiodescrição, oportunizando então, o acesso por alunos com deficiência visual (cegueira e baixa visão).

\section{PRINCIIPAIS REFERÊNCIAS}

ALMEIDA, T. S; ARAUJO, F. V. Diferenças experienciais entre pessoas com cegueira congênita e adquirida: Uma breve apreciação. Revista Interfaces: Saúde, Humanas e Tecnologia, v. 1, n. 2, 2013.

CARNEIRO, B.C.S. Audiodescrição para as pessoas com deficiência intelectual. Babel: Revista Eletrônica de Línguas e Literaturas Estrangeiras, v. 10, n. 1, p. 68-79, 2020.

CHIZZOTTI, A. Pesquisa em Ciências Humanas e Sociais. São Paulo: Cortez. 12 ed.2017.

CONDE, A. J. M. Definição de cegueira e baixa visão. 2017.

CORREAA, T.A et al. Uma experiência didática através da ferramenta stop motion para o ensino de modelos atômicos. HOLOS, v. 6, p. 1-12, 2020.

GIL, A. C. Como Classificar as Pesquisas?. São Paulo: Atlas 4ª ed, p. 41-56, 2002.

GIL, M. Deficiência visual. Brasília: Ministério da Educação, 2000.

LEITE, L et al. Impactos da covid-19 na graduação da pessoa com deficiência visual. Bom Jesus da Lapa. Revista Encantar - Educação, Cultura e Sociedade, v. 2, n. 33, p. 1-14, dez. 2020.

LIMA, F. Áudio-descrição: arte e linguagem a serviço da pessoa com deficiência visual. Disponível em: < http://www.lerparaver.com/node/10690>>. Acesso em: 31 de julho de 2021.

NECO, H.V.P. C; ROCHA, M.F. A ciência é massa: animações stop-motion como estratégia didática em ciências. Pernambuco. Revista Vivências em Ensino de Ciências, v. 2, n. 2, p. 114-120, jun. 2018.

SONZA, A.P; SANTAROSA, L.M.C. Ambientes digitais virtuais: Acessibilidade aos deficientes visuais. Rio Grande do Sul. Novas Tecnologias na Educação, v. 1, n. 1, p. 1-11, fev. 2003. 


\section{RESUMO EXPANDIDO OUTRAS ÁREAS AFINS}




\title{
Rejane Dias Oliveira ${ }^{1}$; Pedro Igor Ferreira da Silva ${ }^{2}$; Cesar Alves do Nascimento ${ }^{3}$; Zilda TIzziana Santos Araújo ${ }^{4}$.
}

\author{
${ }^{1}$ Gradundo, Universidade Estadual do Piauí (UESPI), Piripiri, Piauí. \\ 2 Graduando, Universidade Estadual do Piauí (UESPI), Piripiri, Piauí. \\ 3 Graduando, Universidade Estadual do Piauí (UESPI), Piripiri, Piauí. \\ 4 Docente, Universidade Estadual do Piauí (UESPI), Piripiri, Piauí.
}

PALAVRAS-CHAVE: Pessoas com deficiência; políticas de inclusão; educação inclusiva. ÁREA TEMÁTICA: Outras áreas afins.

\section{INTRODUÇÃO}

O presente trabalho tem por objetivo discutir os aspectos da educação inclusiva no contexto das políticas públicas de inclusão em escolas da rede pública, na perspetiva do que é proposto na lei e o que acontece na realidade. Também temos como base a reflexão sobre a diferença entre a teoria e a prática. Desse modo, por mais que tenha tido avanços relevantes no aspecto da educação inclusiva, ainda há muito a melhorar na nossa sociedade.

Assim, podemos fazer um breve resumo histórico de acordo com Mantoan (2011), a educação especial no Brasil começa no século 19 trazida por brasileiros inspirados em ideias e experimentações americanas e europeias. Esses brasileiros desejavam implementar ações que mesmo que fossem isoladas pudessem beneficiar pessoas com deficiência física, motoras e sensoriais.

Hoje, as pessoas com deficiência vêm conquistado e garantindo seus direitos com bases em importantes leis e uma delas é a Lei 13.146 /15 que assegura direitos já existentes e faz importantes avanços na garantia de novos. Porém, durante muito tempo, esse segmento da população foi desprovido desses direitos. As mudanças de concepções em relação à inclusão de estudantes com deficiência são relevantes progressos na garantia de direitos fundamentais desta população. No entanto, o firmamento de um sistema educacional inclusivo é fundamental para o acesso e continuação de um ensino de qualidade. Percebendo os caminhos percorridos é importante estudar o que vem sendo feito para alcançar um sistema educacional de fato inclusivo.

Sendo assim, é importante ressaltar que umas das principais motivações para escolha desse tema foram as aulas de Fundamentos da Educação Especial, ministradas no curso de Pedagogia da Universidade Estadual do Piauí (UESPI), onde foi possível perceber os avanços que a Educação Especial, na perspectiva inclusiva, teve no Brasil desde a promulgação da constituição de 1988 até o momento atual. Assim sendo, é importante nos percebemos enquanto sociedade que busca a 
inclusão e o desenvolvimento social das pessoas com deficiência, e ampliarmos as investigações para identificarmos se os direitos dessas pessoas estão, realmente, sendo respeitados ou se estão apenas na teoria sem serem praticados.

\section{METODOLOGIA}

A metodologia utilizada no presente trabalho foi a realização de uma pesquisa bibliográfica. Assim, para o desenvolvimento da pesquisa foram feitas leituras e estudos a respeito do tema proposto em artigos, capítulos de livros e Internet. A pesquisa ocorreu de forma remota onde os encontros do grupo para discutir o assunto aconteceram por meio de aplicativos de conversa simultânea como whatsapp e telegram.

\section{FUNDAMENTAÇÃO TEÓRICA}

Atualmente, em nosso país, temos importantes leis de inclusão para pessoas como deficiência dentre elas temos a LDB, o Decreto $n^{\circ} 6.571 / 2008$ e a Lei 13.146/15. A Lei 13.146/15 foi uma grande conquista visto que amplia os direitos para as pessoas com deficiência e inova em relação a direitos fundamentais antes negados, tais como a autonomia para a tomada de decisão e o direito ao trabalho. A LDB 1996, traz no seu capítulo V, algumas prerrogativas para as pessoas com deficiência estabelecem que Educação Especial deve ter o atendimento feito em classes regulares e quando houver necessidade de Atendimento Educacional Especializado (AEE), o aluno público alvo da Educação Especial deverá ter duas matrículas, sendo uma no ensino regular e a outra no AEE.

Assim sendo, o decreto $n^{\circ} 6.571 / 2008$ trata sobre o AEE e coloca em pauta os objetivos desse atendimento: promover a acessibilidade em prédios, condições para os estudantes se manterem na escola, formação continuada de professores e apoio financeiro, dentre outros. Percebe -se que esse Decreto vem para assegurar uma melhor formação, uma vez que o AEE complementa o ensino aprendizagem das pessoas com deficiência.

Assim, nos baseamos no que fala Alencar (1993), quando ela nos fala que existe muito pouco da população com deficiência que recebe quaisquer tipos de atendimento especial, e podemos reafirmar esse pensamento com o autor José Leon 2011, que afirma que o sucesso da educação inclusiva se constitui no fato de que todas as crianças e jovens encontrem-se estudando em escolas e classes regulares.

Considerando esses pressupostos, é necessário lembrarmos que há uma grande diferença entre a teoria, o que o arcabouço legal expressa, e a prática, o que está efetivado nos sistemas de ensino. Na teoria, as leis educacionais de inclusão estão sustentadas num pressuposto de que todas necessidades especiais são sanadas com soluções amplas e majoritárias, quando na verdade é preciso buscar individualmente a dificuldade de cada educando e depois disso priorizar sua solução, ou seja, uma adaptação ao educando e não vice-versa. De acordo com o pensamento de Guimarães (2004), dentro do sistema de educação inclusiva não é esperado que o indivíduo com deficiência se adapte ao currículo escolar, mas que a própria escola sofra mudanças para proporcionar a inserção desse 
indivíduo.

Segundo a Declaração de Salamanca (1994), o ponto inicial e prioritário de uma escola com educação inclusiva está na aprendizagem conjunta de todos os alunos, não importa as dificuldades ou suas diferenças que as mesmas possam ter. Seguindo esse pensamento, o indivíduo com deficiência tem por direito estar inserido em um âmbito escolar que o acolha e que proporcione uma educação justa e com uma qualidade equivalente à dos demais alunos.

A discriminação presente dentro da escola é outro impasse entre a teoria e prática que reforça as dificuldades em disseminar uma educação inclusiva. Segundo a lei 13.146 (BRASIL, 2015) em seu artigo 4, não importa suas necessidades, toda pessoa tem direito a igualdade de oportunidades assegurado e não deve sofrer qualquer tipo de preconceito.

\section{CONSIDERAÇÕES FINAIS}

Baseado em todos os pontos expostos entre a diferença da teoria e prática na educação inclusiva. Conjecturas que na teoria, as leis que promovem uma educação inclusiva abrangem todos os indivíduos que necessitem de cuidados especiais, mas, na prática, sabemos que ainda há muito a ser conquistado, pois, por mais que tenhamos avançados nas garantias de direitos, ainda temos muitas pesssoas que não tem a oportunidades de serem incluidas. Conclui-se, também, que os alunos público alvo da Educação Especial tem o direito de serem matriculados no AEE, serem tratados com igual oportunidades diante daqueles ditos "normais", terem seus direitos respeitados por todos.

Desse modo, nos perguntamos se essas leis e decretos são realmente efetivadas? E o que se percebe é que, por mais que tenha tido avanços nesse quesito, ainda falta muito para que possamos dizer, com segurança, que somos um país que supre todas as necessidades das pessoas com deficiência. Desssa maneira, acreditamos que deve haver uma melhor estruturação do sistema de educação inclusiva para que as pontecialidades desses estudantes seja asseguradas e desenvolvidas de forma correta, as escolas e professores devem serem melhores preparadas para receber esses alunos, que não exista só no papel a disponibilidade de materias didáticos adequados e uso de ferramentos tecnologicas, e o principal investir na concientização de todos para que não aja discriminação de nenhuma parte ou modo dento do ambiente escolar. É notável que mesmo com todos os avanços conquistados quando falamos em educação especial, ainda há um longo caminho a ser percorrido para que a mesma seja difundida corretamente e efetivada de maneira que não aja preconceito. Com isso, reafirma-se a defesa por um ensino regular que promova uma educação de qualidade, ampla, igualitária e livre de qualquer tipo de preconceito.

\section{REFERENCIAS}

ALencar, Eunice M.L. soriano. Educação especial e a realidade brasileira. In: Alencar, Eunice M. Soriano.O Retrato da educação especial no Brasil. Brasília. INEP. 1993. P. 05 a 10.

BRASIL. Lei n.13.146/ 2015. Lei Brasileira de Inclusão da Pessoa com Deficiência. 2015 
BRASIL. Declaração de Salamanca e linha de ação sobre necessidades educativas especiais. Brasília, CORDE, 1994.

BRASIL. Lei Brasileira de diretrizes e Bases da Educação Nacional. LDB. 9394/1996.

BRASIL. Decreto $\quad \mathbf{6 5 7 1 / 0 8} \quad$ Disponível em

https://www2.camara.leg.br/legin/fed/decret/2008/decreto-6571-17-setembro-2008580775publicacaooriginal-103645-pe.html acesso em 04/09/2021.

CROCHÍK, José Leon. Educação inclusiva e preconceito desafios para a Prática pedagógica in: CROCHÍK, José Leon. O professor e a educação inclusiva formação, práticas e lugares. Salvador: EDUFBA, 2012. P.39 a 57.

GUIMARÃES, A Inclusão que funciona. Revista Nova Escola, São Paulo, p .43-47, set. 2003. 


\section{GESTÃO DO NÚCLEO DE PESQUISA E EXTENSÃO EM DESTAQUE: ÉTICA, DIVERSIDADE E INCLUSÃO - UM RELATO DE EXPERIÊNCIA}

\section{Iane Rocha Mendes ${ }^{1}$.}

${ }^{1}$ Bacharela em Direito. Mestranda em Educação e Diversidade. UNEB, Jacobina, Bahia.

PALAVRAS-CHAVE: Extensão. Diversidade. Inclusão.

ÁREA TEMÁTICA: Outras áreas afins.

\section{INTRODUÇÃO}

Nos tempos atuais, a extensão tem centralidade nos fazeres acadêmicos. Compondo a tríade ensino-pesquisa-extensão, ela promove a parceria, o compartilhamento, a união entre a Universidade e a comunidade. Nos Departamentos da Universidade do Estado da Bahia (UNEB), a ponte mais íntima entre a Academia e a comunidade é realizada pelo Núcleo de Pesquisa e Extensão (NUPE), ao propiciar as condições necessárias para que as atividades extensionistas venham a acontecer. Este relato de experiência tem o objetivo de descrever como o acompanhamento da equipe gestora do NUPE, Departamento de Ciências Humanas - Campus IV - UNEB, no projeto de extensão "A Comunicação Alternativa e Ampliada na mediação de textos para pessoas no Espectro do Autismo", ocorrido no ano de 2019, alicerçou conceitos éticos, inclusivos e de diversidade, ao tempo em que demonstrou de perto desafios que ainda precisam ser enfrentados.

\section{METODOLOGIA}

O projeto de extensão "A Comunicação Alternativa e Ampliada na mediação de textos para pessoas no Espectro do Autismo" ocorreu no segundo semestre do ano de 2019 no Departamento de Ciências Humanas - Campus IV da UNEB e contou com o apoio do NUPE, do Colegiado de Letras Língua Inglesa e Literaturas e da Direção/Coordenação geral do Departamento. O público-alvo do curso configurou-se em: alunos/as de graduação e pós-graduação da UNEB e de outras instituições de ensino superior, profissionais da educação em geral, profissionais da saúde interessados/as na temática e comunidade local interessada.

\section{RESULTADOS E DISCUSSÕES}

Ao longo de um ano inteiro de trabalho no Núcleo de Pesquisa e Extensão da UNEB, acompanhamos vários cursos e projetos de extensão. Partindo desde aqueles mais pequenos com eventos que duram uma tarde ou uma noite até aqueles maiores que podem durar o ano inteiro. Tudo é desafiador da mesma maneira, da mesma forma. A cada nova atividade que recebemos, temos que rever, renovar, criar estratégias para poder dar conta de acompanhar todos os movimentos. 
Com o curso de extensão "A Comunicação Alternativa e Ampliada na mediação de textos para pessoas no Espectro do Autismo" não foi diferente. Ou até foi, em certa medida. Primeiramente este curso chegou até o NUPE de uma maneira inesperada: ele estava atrelado a uma disciplina de Estágio Curricular Supervisionado do curso de Licenciatura em Letras, Língua Inglesa e Literaturas e essa era a primeira vez que trabalharíamos com extensão e ensino tão próximos. Mas os/as responsáveis pelo curso gostariam de abrí-lo para a comunidade externa e coube ao NUPE a tarefa de fazer essa ponte.

Desse modo, aliados/as com o colegiado do curso (na figura da e do discente e da professora orientadora da discente e extensionista) nós começamos um trabalho intenso de divulgação, juntos. Essa experiência já começava nos mostrando a potência que as disciplinas de estágio tinham para trabalhar num viés extensionista, trazendo a comunidade para perto da Universidade e compartilhando saberes juntamente com ela. Foi um sucesso de inscrições! A gestão do NUPE, responsável por acompanhar as inscrições da comunidade externa ao projeto, viu chegar mais pessoas do que o previsto, obrigando todo mundo a pensar: onde vamos colocar tantas pessoas?

Gostaria de deixar aqui uma das maiores dificuldades que temos ao acompanhar e gerenciar os cursos e projetos de extensão do Departamento: falta espaço para quase tudo! Fazer mais de um evento no mesmo horário? Quase impossível. E apesar de não ser o NUPE o responsável pela reserva dos locais onde serão realizados os eventos, quando não dá certo, somos nós os primeiros procurados para resolver o impasse. No caso do curso em questão, não havia mais espaço no auditório para comportá-lo, nos pátios havia barulho demais e as salas estavam todas ocupadas. O que fazer? À época, em meio ao desespero de não conseguir encontrar lugar para o curso de extensão, encontramos a sala da futura brinquedoteca do Departamento vazia, ainda por ser finalizada. Era a única chance. A direção liberou e o curso aconteceu lá mesmo, em meio a janelas ainda com plástico e caixas de brinquedos pelo chão.

À altura do acompanhamento dos encontros, mais percalços para a gestão. O curso de extensão acontecia à noite e a equipe do NUPE só trabalhava durante os turnos diurnos. Temos uma equipe pequena, à época formada por uma coordenadora (professora que para além das atribuições do núcleo, precisa dar aulas e fazer orientações), uma técnica administrativa (eu) e mais uma estagiária (que trabalha somente $4 \mathrm{~h}$ por dia). O curso de extensão trazia uma demanda nova que atraiu muitas pessoas, além de ser realizado também como uma atividade de estágio em componentes do eixo de ensino. O NUPE devia fazer esse acompanhamento de perto, zelando pela comunidade externa ali presente e assegurando um bom desenvolvimento como um todo das atividades. Fiquei mais tempo no trabalho durante uns três meses sem contar horas extras, o retorno foi muito satisfatório.

Um outro ponto que merece ser destacado diz respeito ao quanto nós da equipe gestora do NUPE aprendemos com este curso de extensão: felizmente, com a política de cotas da Universidade, temos acompanhado um número crescente de pessoas com deficiência e transtornos adentrando os cursos de graduação e pós-graduação. Acompanhar de perto o desenvolvimento deste cursos de extensão nos rendeu muitas experiências interessantes e importantes, no sentido de evoluirmos o nosso espaço de trabalho, de modo que ele venha a ser cada vez mais inclusivo. 
Ao final do curso (que foi um absoluto sucesso de público e inspirou projetos de pesquisa e iniciação científica - completando assim a tríade ensino-pesquisa-extensão, coisa que poucos cursos conseguem fazer), partimos para a finalização das atividades: é papel do NUPE certificar os/as participantes do curso, validar os relatórios e alimentar os sistemas. Fizemos isso com muita satisfação, com a sensação de estarmos cumprindo para com os nossos compromissos éticos, inclusivos e principalmente colaborando com uma formação completa pautada na diversidade.

\section{CONSIIDERAÇÕES FINAIS}

Ainda há muito que caminhar nesta trajetória de gestão do Núcleo de Pesquisa e Extensão. Muitos dos desafios elencados anteriormente se repetem a cada novo curso que vamos acompanhar. É necessário que a Universidade repense os seus espaços e propicie cada vez mais lugares para a extensão, para não precisarmos ocupar espaços não concluídos por não haver outros lugares disponíveis. Também é necessário pensar na ampliação da equipe gestora do NUPE, de modo a conseguirmos acompanhar os cursos e projetos de forma mais eficiente e sem ultrapassar a nossa carga horária diária. Sabemos que os desafios são grandes e reconhecemos a luta da Universidade por mais recursos para todas as ações do Departamento, incluindo a extensão. Porém, não podemos deixar de tecer essas críticas construtivas advindas da experiência no acompanhamento do curso de extensão elencado.

Os documentos norteadores da Universidade dizem com muita clareza o que é a extensão e como ela, teoricamente, deve acontecer. Mas ao nos deslocarmos para a prática, encontramos realidades muitas vezes opostas e temos que trabalhar com os poucos recursos disponíveis. A gestão do NUPE precisa sempre estar atenta, buscando a garantia de espaços e oportunidades de ampliação de conhecimentos tanto para a comunidade interna quanto para a comunidade externa, ao tempo que luta diariamente para desenvolver um trabalho ético, inclusivo e pautado na diversidade.

\section{PRINCIPAIS REFERÊNCIAS}

BASTOS, Manoel de Jesus. A Importância da Ética na Educação. Revista Científica Multidisciplinar Núcleo do Conhecimento. Edição 05. Ano 02, Vol. 01. p. 264-276, Julho de 2017. ISN: 2448 - 0959. Link de acesso: https://www.nucleodoconhecimento.com.br/educacao/etica-na-educacao, DOI: 10.32749/nucleodoconhecimento.com.br/educacao/etica-na-educação.

BRASIL. Política Nacional de Extensão Universitária. Manaus: Fórum de Pró-Reitores de Extensão das Universidades Públicas Brasileiras, 2012. Disponível em: https://portal.uneb.br/proex/ wp-content/uploads/sites/62/2018/02/2012-07-13-Politica-Nacional-de-Extensao.pdf. Acesso em 31.07.2021.

CARDOZO, Maria José Pires Barros. LIMA, Francisca das Chagas Silva. Diversidade e gestão democrática no contexto educacional. Santarém/PA: Revista Exitus, Vol. 8, № 1, JAN/ABR 2018, p. 87 - 111. 
LUZ, Rosângela Maria Nunes da. SARTORI, Jerônimo. Gestão escolar na perspectiva da educação inclusiva. Universidade Federal da Fronteira do Sul (UFFS), 2018, p. 4. Disponível em: https:// rd.uffs.edu.br/handle/prefix/2030. Disponível em: https://rd.uffs.edu.br/handle/prefix/2030. Acesso em: 31.07.2021.

UNIVERSIDADE DO ESTADO DA BAHIA. Conselho Universitário (CONSU). Regimento Geral dos Núcleos de Pesquisa e Extensão da UNEB. Bahia, 2019. Disponível em: https://portal.uneb.br/ conselhos/wp-content/uploads/sites/103/2019/07/1361-consu-Res.-Regimento-Geral-dos-NUPEs. pdf. Acesso em 31.07.2021. 


\title{
RESUMO EXPANDIDO
}

\author{
POLÍTICAS EDUCACIONAIS: \\ GESTÃO ESCOLAR, FORMAÇÃO DOCENTE E \\ INCLUSÃO
}




\section{GEOTECNOLOGIAS COMO SUBSÍDIO PARA A INCLUSÃO DE PESSOAS COM DEFICIÊNCIA NO AMBIENTE ESCOLAR EM RIO BRANCO, ACRE}

\section{Victor Régio da Silva Bento'.}

${ }^{1}$ Doutor em Geografia, Universidade Federal do Acre, Rio Branco, Acre.

PALAVRAS-CHAVE: Geotecnologias. Pessoas com Deficiência. Indicadores educacionais.

ÁREA TEMÁTICA: Políticas Educacionais: gestão escolar, formação docente e inclusão.

\section{INTRODUÇ̃̃O}

As Geotecnologias são ferramentas para coleta, processamento, análise e mapeamento de informações espaciais, que foram aprimoradas com o advento da informática. São exemplos os Bancos de Dados Geográficos, os sistemas de posicionamento global - GPS, a cartografia digital e o sensoriamento remoto. Elas podem ser utilizadas em diversas aplicações, inclusive na análise de indicadores educacionais e políticas públicas de inclusão social.

A aplicação das Geotecnologias na análise espacial de indicadores que dão visibilidade às Pessoas com Deficiência PcD, é relevante para identificar as disparidades existentes na universalização da inclusão. A Lei Brasileira de Inclusão da Pessoa com Deficiência determina em seu artigo segundo, a definição de PcD como o indivíduo que possui "impedimento de longo prazo de natureza física, mental, intelectual ou sensorial, o qual, em interação com uma ou mais barreiras, pode obstruir sua participação plena e efetiva na sociedade em igualdade de condições com as demais pessoas" (BRASIL, 2015, p. 02). Essa legislação assegura os direitos fundamentais de PcD à educação, profissionalização, trabalho, transporte, acessibilidade, habilitação e reabilitação.

Sabe-se que a realidade da Educação Básica brasileira é bastante desigual nos estados e regiões, tanto pela localização urbana ou rural, quanto pelo tipo de esfera administrativa (federal, estadual, municipal, privada). Além das disparidades geográficas e de gestão, é perceptível que a ausência de equipamentos e dependências basilares como biblioteca, quadra de esportes e laboratório de informática é marcante nas instituições de ensino fundamental e médio. Esses problemas estruturais repercutem negativamente na aprendizagem dos alunos, principalmente daqueles que possuem alguma deficiência, visto que essa parcela da comunidade escolar necessita de recursos específicos como salas de Atendimento Educacional Especializado - AEE, profissionais capacitados e acessibilidade (rampas, banheiros adaptados, piso tátil). As barreiras para os PcD são enfrentadas antes mesmo da entrada na escola, dada a precariedade da mobilidade urbana, expressas nas condições das ruas e calçadas.

A Geotecnologias, na figura dos bancos de dados geográficos e da cartografia temática, pode ser uma importante ferramenta de apoio à detecção de fatores limitantes à inclusão de PCD nos espaços escolares. A utilização de microdados do censo escolar (INEP, 2019) e dos censos 
demográficos (IBGE, 2010) contribuem para uma análise multivariada de indicadores sobre as diversas deficiências. Com os dados educacionais é possível verificar a distribuição espacial dos $\mathrm{PcD}$ e as escolas com maior dificuldade de prestar um atendimento especializado, dada a carência de equipamentos, salas e profissionais. Já as informações censitárias possibilitam um entendimento das dificuldades de inclusão para além do ambiente escolar, verificando as condições urbanísticas no entorno das instituições de ensino.

O Censo Escolar 2018 revelou o crescimento na matrícula de alunos com deficiência em todas as etapas da educação básica, alcançando 1,2 milhão de matrículas, um aumento de 33,2\% em relação a 2014 (INEP, 2019). No entanto, os desafios da acessibilidade ocorrem para além da escola, conforme visto no último censo demográfico do IBGE, o qual revelou que apenas 4,7\% das ruas brasileiras possuem rampa para cadeira de rodas (ANDRADE, 2012). As dificuldades para inclusão de PcD no ambiente escolar são evidenciadas pela ausência de estruturas essenciais como banheiro adaptado, sala de AEE, materiais didáticos, elevador ou rampa de acesso para os pisos superiores e quadra de esporte coberta (DISCHINGER, 2009). Considerando o que foi exposto, o presente trabalho objetivou aplicar geotecnologias como ferramentas para análise espacial de indicadores educacionais e infraestruturais destinados às políticas públicas de inclusão de $\mathrm{PcD}$. Os dados selecionados são oriundos Instituto Nacional de Estudos e Pesquisas Educacionais Anísio Teixeira (INEP, 2019) e do Censo Demográfico do Instituto Brasileiro de Geografia e Estatística (IBGE, 2010). A zona urbana de Rio Branco, capital do estado do Acre, foi selecionada como recorte espacial para pesquisa. A escolha de uma cidade amazônica justifica-se pelas dificuldades para a universalização da alfabetização e da inclusão de PcD na Região Norte do Brasil, caracterizada como um extenso território com população rural dispersa, marcada pela distância entre os centros urbanos e pelas dificuldades de transporte.

\section{METODOLOGIA}

O recorte espacial da pesquisa abrangeu o perímetro urbano de Rio Branco, tendo em vista que a concentração de escolas na sede municipal é mais expressiva que na zona rural, o que possibilita melhor comparação entre as instituições de ensino e o cruzamento com as informações urbanísticas do IBGE.

Após a delimitação espacial, foram extraídos os microdados educacionais do INEP, referentes ao censo escolar de 2019. Dentre as informações analisadas destacam-se: classificação das instituições por etapa da Educação Básica - Educação Infantil, Ensino Fundamental (anos iniciais e finais) e Ensino Médio; divisão por dependência administrativa - federal, estadual, municipal e privada; catalogação dos alunos por tipo de deficiência - cegueira, baixa visão, auditiva, surdocegueira, física, intelectual, múltipla, autismo e superdotação; distribuição das deficiências por faixa etária e sexo; e análise dos equipamentos e infraestruturas à exemplo da Sala de AEE, pisos táteis e rampas.

Os indicadores de infraestrutura foram adquiridos dos agregados de setores censitários do IBGE, referentes ao censo demográfico de 2010. Os dados analisados abordam as características urbanísticas do entorno dos domicílios, as quais influenciam na acessibilidade, a saber: presença de calçadas, vias pavimentadas e rampas de acesso à cadeira de rodas. 
Posteriormente, como o auxílio EXCEL, os dados foram estruturados com funções para remoção de duplicatas, contagem (CONT.SE e CONT.SES) e soma (SOMA.SE). Assim, obteve-se o agrupamento dos alunos para cada escola, considerando o tipo de deficiência, sexo e idade. Para esse estudo foram selecionadas três bases cartográficas: as escolas, as regionais administrativas e os setores censitários (Figura 1). As escolas foram georreferenciadas com a utilização do software Google Earth e posteriormente identificadas com o Geocódigo do INEP. As Regionais Administrativas de Rio Branco serviram como base para o mapeamento dos dados escolares na escala intraurbana. A base de setores censitários foi requerida para espacialização das informações urbanísticas do IBGE.

A vinculação das tabelas CSV às bases cartográficas, análise espacial e mapeamento temático ocorreram com a utilização do programa de geoprocessamento Quantum GIS 3.16. A representação pontual das escolas possibilitou a elaboração de mapas de calor ou "heatmaps", que mostram a intensidade de alunos PcD na zona urbana de Rio Branco. Os polígonos de setores censitários serviram como recorte espacial para a geração de cartogramas temáticos sobre as características urbanísticas do entorno do domicílio (Figura 1).

Figura 1: Bases cartográficas da pesquisa e exemplos de mapas de calor e cartogramas gerados.

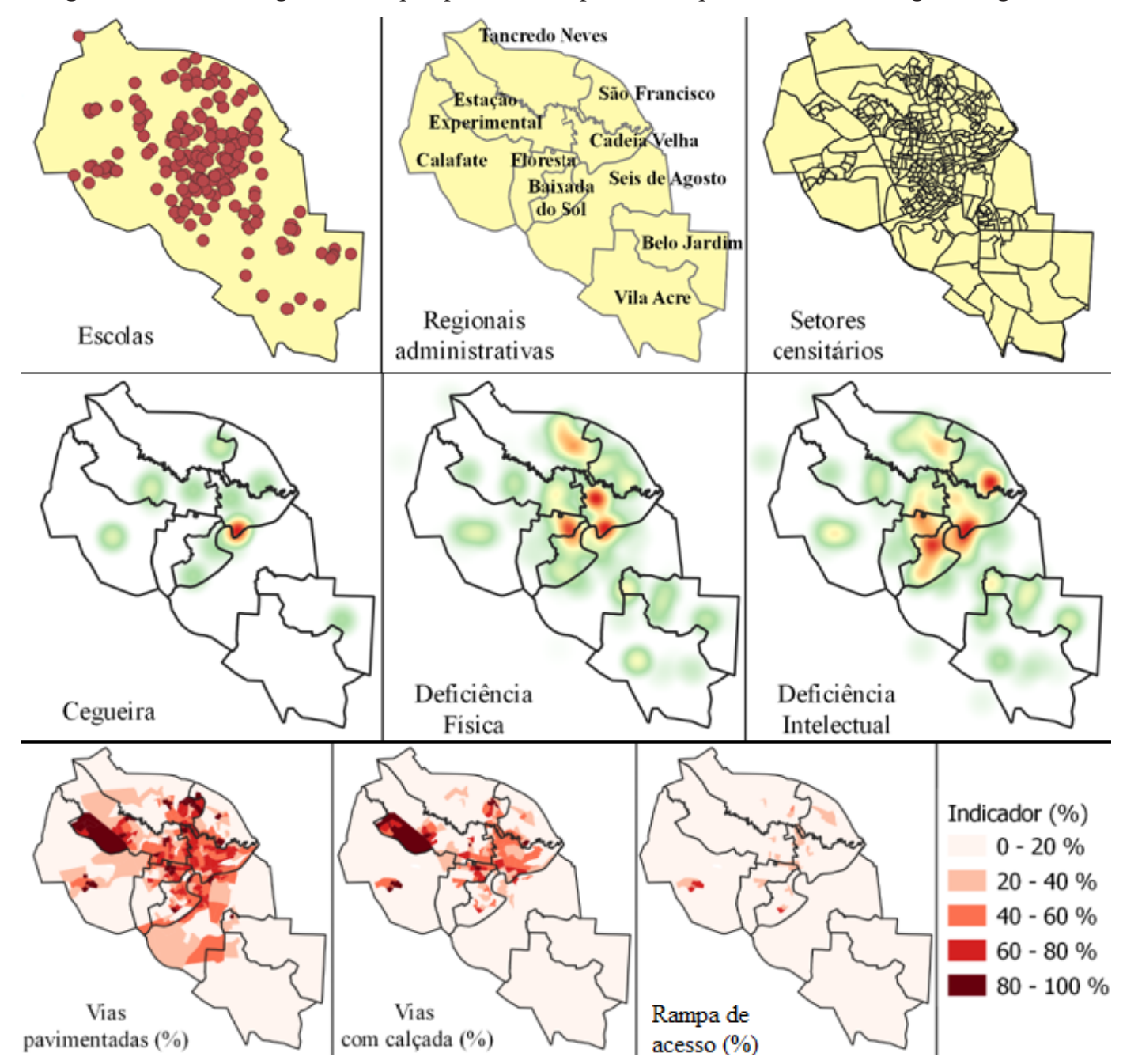

Fonte: IBGE, Censo Demográfico, 2010 e INEP, Censo Escolar, 2019. Elaborado pelo autor. 


\section{RESULTADOS E DISCUSSÕES}

Os microdados do censo escolar de 2019 revelaram, na área urbana de Rio Branco, 102.027 alunos matriculados em 201 escolas e, desse total, 7.296 eram $\operatorname{PcD}$ (7,15\%). As deficiências são mais evidentes no sexo masculino (9,77\%), do que no feminino (4,48\%). As deficiências distribuem-se na seguinte proporção: Intelectual (64,67\%), Autismo (22,52\%), Deficiência Física (10,50\%), Deficiência Múltipla (7,40\%), Baixa Visão (6,55\%), Superdotação (3,37\%), Surdez (2,29\%), Cegueira (0,42\%) e Surdocegueira $(0,03 \%)$.

Para análise na escala intraurbana de Rio Branco foi realizado o cruzamento entre diferentes bases cartográficas as quais evidenciaram desigualdades da inclusão de PcD nos espaços escolares. As dez regionais administrativas da capital acreana serviram como suporte para o georreferenciamento das escolas. Dentre algumas considerações, a Regional Calafate mereceu destaque quanto a presença de rampas de acessibilidade no entorno escolar. A Regional São Francisco precisa de uma atenção especial do poder público, pois concentra a maior proporção de alunos $\mathrm{PcD}$ em relação ao total de matrículas. Cadeia Velha e Sobral são as duas regionais com o maior quantitativo absoluto de alunos PcD. Elas são estratégicas pela disponibilidade do transporte público e por abrigar importantes equipamentos educacionais. As regionais Estação Experimental, Floresta e Tancredo Neves possuem boa qualidade urbanística, nas escolas situadas em conjuntos habitacionais e no entorno das instituições de ensino superior. Em contraposição as Regionais Belo Jardim e Vila Acre são caracterizadas pela ocupação populacional recente, com escassez das infraestruturas urbanas e transporte coletivo, o que impacta diretamente na acessibilidade às escolas.

\section{CONSIDERAÇÕES FINAIS}

O estudo em questão mostrou possibilidades de utilização das geotecnologias como ferramentas para análise espacial. Através delas, indicadores podem ser empregados para políticas públicas destinadas à inclusão de alunos PcD nos espaços escolares. Os dados educacionais e de infraestrutura mapeados no trabalho contribuíram para desvendar onde há maiores demandas da Educação Básica no espaço intraurbano de Rio Branco. A desigualdade da educação e da infraestrutura urbana, quando intercruzadas, refletem os desafios enfrentados para universalização do atendimento especializado, condições de infraestrutura, materiais didáticos e das condições de acessibilidade no entorno das instituições de ensino. A inclusão de PcD deve ser pauta nas políticas educacionais e de planejamento urbano, assegurando a aprendizagem e o direito de ir e vir.

\section{REFERÊNCIAS}

ANDRADE, Henrrikson. IBGE mostra que apenas 4,7\% das ruas do país têm rampa para cadeirante. Notícias Uol (On-line), 2012 Disponível em: <https://noticias.uol.com.br/cotidiano/ultimasnoticias/2012/05/25/ porto-alegre-se-destaca-em-estudo-do-ibge-com-quase-25-de-ruas-adaptadaspara-cadeirantes.htm>. Acesso e 15 ago. 2021.

BRASIL. Lei n ${ }^{\circ}$ 13.146, de 06 de julho de 2015. Institui a Lei Brasileira de Inclusão da Pessoa com 
Deficiência (Estatuto da Pessoa com Deficiência). Diário Oficial da União, Brasília, DF, 07 jul. 2015. Seção 1, p. 2.

DISCHINGER, Marta. Manual de acessiblidade espacial para escolas: o direito à escola acessível. Brasília: Ministério da Educação, Secretaria de Educação Especial, 2009.

IBGE. Agregado de setores censitários 2010. Rio de Janeiro: IBGE, 2010.

INEP. Censo escolar 2019 (microdados). Brasília: Ministério da Educação, 2019. Disponível em: $<$ https://www.gov.br/inep/pt-br/acesso-a-informacao/dados-abertos/microdados $>$ Acesso em 28 jul. 2021. 


\section{João Pedro Ponciano'; Aguinaldo Robinson de Souza ${ }^{2}$.}

${ }^{1}$ Graduando Licenciatura em Química, Unesp, Bauru, São Paulo.

${ }^{2}$ Doutor em Química, Unesp, Bauru, São Paulo.

PALAVRAS-CHAVE: Educação Especial. Inclusão. Formação.

ÁREA TEMÁTICA: Políticas Educacionais: gestão escolar, formação docente e inclusão.

\section{INTRODUÇÃO}

Quando tentamos elucidar a importância da educação, vários são os autores que abordam o tema, porém, é na fala de um antigo pedagogo que ela foi bem definida; Comenius (2001) descreve o processo de aprendizagem do homem análogo ao crescimento de uma árvore, onde, no trecho de sua obra, o autor enfatiza:

Do que foi dito, é evidente que é semelhante a condição do homem e a da árvore. Efetivamente, da mesma maneira que uma árvore de fruto (uma macieira, uma pereira, uma figueira, uma videira) pode crescer por si e por sua própria virtude, mas, sendo brava, produz frutos bravos, e para dar frutos bons e doces tem necessariamente que ser plantada, regada e podada por um agricultor perito, assim também o homem, por virtude própria, cresce com feições humanas (como também qualquer animal bruto cresce com as suas feições próprias), mas não pode crescer animal racional, sábio, honesto e piedoso, se primeiramente nele se não plantam os gérmens da sabedoria, da honestidade e da piedade. Agora importa demonstrar que esta plantação deve ser feita enquanto as plantas são novas. (COMENIUS, 2001, pag. 111).

Entretanto, é necessário saber que, muitas vezes, esse cuidado e direcionamento não podem ser unicamente na fase infantil, pois, pessoas com deficiência necessitam acompanhamento contínuo em todas as fases durante o processo de aprendizagem. Sendo assim, quando a adaptação curricular é bem elaborada, a escola pode desenvolver metodologias e estratégias eficazes na educação inclusiva, pois, segundo Comenius (2001, p. 48) “Às escolas, porque, corrigido o método, poderão, não só conservar-se sempre prósperas, mas ser aumentadas até ao infinito. Com efeito, serão verdadeiramente um divertimento, casas de delícias e de atrações [...]". 
Quando uma análise histórica, política e crítica é feita sobre o percurso da educação inclusiva no cenário brasileiro, é notável que é um trajeto de avanços e retrocessos e/ou, muitas vezes, caminhada em círculos em torno do tema, sendo que, os conteúdos de documentos oficiais podem proporcionar interpretações equivocadas ou distantes da realidade. Sobre as possíveis compreensões, Neto e Veraszto (2020) destacam o conceito da educação inclusiva, onde ela não é apenas direcionada às pessoas com Necessidades Educativas Especiais (NEE), ou que tenham algum tipo de deficiência, distúrbio ou superdotação; educação inclusiva deve ser mais abrangente, englobando todos os alunos de uma sala de aula (classe multisseriada, étnico-religioso, étnico-racial entre outros), pois, todos os alunos devem ser tratados como Público-alvo da educação especial (PAEE).

Para Vygotsky (1997), o homem e sua consciência estão atrelados ao meio externo, ou seja, com suas bagagens, sócio-histórico, da maneira que o sujeito, enquanto ser pensante, apresenta diversas interações em diferentes níveis culturais, e, através dessa relação, adapta-se às possibilidades oferecidas, mas sempre mediada por símbolos que propiciam, a cada indivíduo, uma experiência diferente. Dessa forma, a cada novo tema apresentado, a princípio através de um tutor, o sujeito desenvolve autonomia pelas relações heterogêneas em suas experiências.

Um importante marco para inclusão foi a reunião que ocorreu, em Salamanca na Espanha em 1994, com a participação de vários países, culminando na Declaração de Salamanca (1994), que estabeleceu que, todas as crianças com ou sem deficiência, em situação de rua, refugiadas ou outras situações, deveriam ser matriculadas na escola, promovendo a educação para todos; nesse contexto, podemos destacar o seguinte trecho do documento:

\footnotetext{
- as crianças e jovens com necessidades educativas especiais devem ter acesso às escolas regulares, que a elas se devem adequar por meio de uma pedagogia centrada na criança, capaz de ir ao encontro destas necessidades;

- as escolas regulares, seguindo esta orientação inclusiva, constituem os meios mais capazes para combater as atitudes discriminatórias, criando comunidades abertas e solidárias, construindo uma sociedade inclusiva e atingindo a educação para todos; além disso, proporcionam uma educação adequada à maioria das crianças e promovem a eficiência, numa ótima relação custo-qualidade, de todo o sistema educativo. (DECLARAÇÃO DE SALAMANCA, 1994).
}

Para que isso ocorra, é necessário que futuros professores, em suas graduações, tenham contato com a temática "inclusão". No entanto, no Brasil, nos cursos de licenciatura, a disciplina é obrigatória apenas na formação de Língua Brasileira de Sinais (LIBRAS), sendo garantida pelo decreto $n^{\circ} 5.626$, de dezembro de 2005 (BRASIL, 2005). Dessa forma, o professor, em sua formação, comumente tem contato apenas com a cultura surda e sem aprofundamentos, pois a disciplina é ofertada, na maioria das vezes, em apenas um semestre, e, na ausência de novos decretos, aprofundamentos sobre outras deficiências não são oferecidas na graduação. 
Nessas idas e vindas, a educação inclusiva vai se moldando, ora pelas tentativas de vencer obstáculos, ora retrocedendo quando surgem novos desafios, pois, "Diante de todo o exposto, se verifica que a composição da legislação/elementos diretivos analisados da educação brasileira se constituem numa verdadeira colcha de retalhos, à medida que se incorporam e modificam todo o cenário educacional sobre ela" (NETO; VERASZTO, 2020, p. 42).

\section{METODOLOGIA}

A quantidade de pesquisas relacionadas ao tema "inclusão e educação especial" nos últimos anos teve um aumento significativo, tanto para a educação quanto à psicologia, ganhando grande visibilidade, mas ainda sendo necessário mais cursos de capacitação e aperfeiçoamento na formação desses profissionais.

Alunos com NEE, matriculados em salas regulares, podem se sentir em desvantagem perante aos outros colegas da sala de aula, não por causa de sua condição (física ou intelectual), mas pela falta de capacitação do docente responsável pela sala de aula na área de educação especial e inclusiva. Diante disso, o despreparo do professor pode acarretar em uma educação exclusiva ao invés de inclusiva, já que os docentes, em suas formações, são preparados, em sua maioria, para educar alunos considerados "normais".

Posto isso, o presente trabalho é focado na análise de trabalhos já publicados sobre essa temática, de modo a compreender os prejuízos em consequência da falha na formação dos docentes na educação inclusiva nos cursos de licenciatura e o impacto no ensino-aprendizagem dos alunos PAEE matriculados em classes regulares.

\section{FUNDAMENTAÇÃO TEÓRICA}

A educação inclusiva, nos componentes curriculares de licenciados na área de ciência, ainda possui muitas lacunas. As disciplinas com conteúdos sobre o tema são recentes nas instituições de ensino superior, ou, em muitas delas, ainda inexistentes, o que caracteriza uma formação falha ao docente (GONÇALVES et al, 2013; LIPPE, ALVES e CAMARGO, 2012; PEREIRA et al, 2011; SILVA e DAMASCENO, 2015), onde o professor é qualificado apenas a lecionar em uma classe regular, com alunos normais, desconsiderando os alunos com NEE, como é apontado por Pereira et al (2011).

O professor só está apto a transmitir aquilo que ele recebeu como conhecimento em sua formação, e, se não teve contato com a educação inclusiva, certamente não atingirá as expectativas em uma sala que necessite de didática inclusiva, pois, ao realizar adaptações de suas ações pedagógicas, no intuito de contemplar o aprendizado de todos os alunos, acarretará em trabalho extra, e a falta de tempo, torna o processo cansativo e dificultoso (LIPPE, ALVES e CAMARGO, 2012; SILVA e DAMASCENO, 2015), inconscientemente tornando as aulas em uma vivência de exclusão para os alunos PAEE. Para que as adaptações curriculares ou as ações pedagógicas sejam possíveis, o professor, seja pluralista em seu repertório de conhecimentos teóricos e práticos, e cultivando com 
ele, a sensibilidade do ofício de ensinar, pois, é ele o intermediário para que o aprendizado chegue aos alunos (CRUZ, 2007), mas essa pluralidade se torna singular, quando o docente frente a uma sala de aula, não tenha essa percepção de educação inclusiva.

Dessa forma, a problemática da falta da educação inclusiva na formação do docente é sentida pelos alunos PAEE, que frequentam as classes regulares, destoando dos outros estudantes, frequentando séries diferentes da indicada pelo MEC, ocasionando reprovações e evasão (PEREIRA et al, 2011; SILVA e DAMACENO, 2015). Portanto, é primordial que os professores consigam, em seu processo formativo (inicial ou continuado), apropriar-se de conhecimentos sobre a educação inclusiva, não que garantam preparo para todas situações inclusivas, mas possibilite pensar em novas estratégias de ensino-aprendizagem para situações que, em algum momento, exigirão o mínimo de conhecimento.

Para Lippe, Alves e Camargo (2012) os velhos modelos de ensino ainda estão enraizados nos dias atuais, sendo prejudicial ao desenvolvimento e aplicação da educação inclusiva, tanto na formação e capacitação do professor quanto no ensino voltado para os alunos PAEE, revelando que o prejuízo é exclusivamente do aluno com deficiência, inserido em sala regular, sem que esteja, de fato, incluído no processo de ensino-aprendizagem.

\section{CONSIDERAÇÕES FINAIS OU CONCLUSÃO}

O trabalho evidenciou que a responsabilidade pela falta de inclusão não se deve a um único fator, mas está vinculado a um conjunto, formando um ciclo. Se faz necessário um planejamento para que tais fatores, como a falta de disciplinas sobre educação inclusiva nos cursos de licenciatura, os velhos modelos de ensino presentes em algumas instituições de ensino e a falta da formação continuada dos docentes, sejam solucionados e que literalmente a educação inclusiva aconteça, deixando de ser utópico e seja tangível aos que necessitam. A presente pesquisa trouxe a reflexão sobre como podemos mudar a realidade da educação inclusiva, conhecendo e reconhecendo seus retrocessos, os prejuízos sofridos pelo aluno PAEE em seu processo de ensino-aprendizagem em consequência da má formação do docente dentro desse contexto.

\section{REFERÊNCIAS}

BRASIL. Ministério da Educação. Secretaria de Educação Especial. Decreto $\mathbf{n}^{\circ}$ 5.626, 22 de dezembro de 2005. Regulamenta a Lei $\mathrm{N}^{\circ}$ 10.436, de 24 de abril de 2002, que dispõe sobre a Língua Brasileira de Sinais - Libras, e o art. 18 da lei ${ }^{\circ}$ 10.098, de 19 de dezembro de 2000. Disponível em: http:/www.planalto.gov.br/ccivil_03/_ato2004-2006/2005/decreto/d5626.htm. Acesso em 15 de agosto de 2021

COMENIUS. I. A. Didática Magna. Introdução, Tradução e Notas de Joaquim F. Gomes. eBooksBrasil, 2001, 595 pag. Disponível em: http:/www.ebooksbrasil.org/adobeebook/didaticamagna.pdf.

CRUZ, G. B. da. A prática docente no contexto da sala de aula frente às reformas curriculares. Educar em Revista, [S.L.], n. 29, p. 191-205, 2007. FapUNIFESP (SciELO). http://dx.doi.org/10.1590/ 
s0104-40602007000100013.

DECLARAÇÃO DE SALAMANCA: Sobre princípios, políticas e práticas na área das necessidades educativas especial. Salamanca - Espanha, 1994.

GONÇALVES, F. P. et al (ed.). A Educação Inclusiva na Formação de Professores e no Ensino de Química: A Deficiência Visual em Debate. Química Nova na Escola, São Paulo, v. 35, n. 4, p. 264271, nov. 2013. Trimestral. Disponível em: http://qnesc.sbq.org.br/online/qnesc35_4/08-RSA-100-11. pdf.

LIPPE, E. O.; ALVES, F. de S.; CAMARGO, E. P. de. ANÁliSE DO PROCESSO INCLUSIVO EM UMA ESCOLA ESTADUAL NO MUNICÍPIO DE BAURU: A VOZ DE UM ALUNO COM DEFICIÊNCIA VISUAL. Ensaio Pesquisa em Educação em Ciências (belo Horizonte), [s.l.], v. 14, n. 2, p. 81-94, 2012. Disponível em: https://periodicos.ufmg.br/index.php/ensaio/article/ view/10253/7207.

NETO, O. A. de S.; VERASZTO, E. V. Perspectivas de inclusão escolar em aulas de Ciências da Natureza e da Matemática: estudo de caso em escola do interior paulista. 1. ed. - Belém: Rfb Editora, 2020.

PEREIRA, L. de L. S. et al. Aula de Química e Surdez: sobre Interações Pedagógicas Mediadas pela Visão. Química Nova na Escola, [S.I], v. 33, n. 1, p. 47-56, fev. 2011. Trimestral. Sociedade Brasileira de Química (SBQ). Disponível em: http://qnesc.sbq.org.br/online/qnesc33_1/07-AF4510. pdf.

SILVA, W. D. A.; DAMASCENO, M. M. S. A Química no Contexto da Educação Especial: O Professor, O Ensino e a Deficiência Visual. REDEQUIM: Revista Debates em Ensino de Química, [s.i], v. 1, n. 1, p. 20-28, out. 2015. Semestral.

VYGOTSKI, L. S. Obras Escogidas V: fundamentos de defectología. Madrid: Gráficas Rogar, 1997. 


\section{RESUMO EXPANDIDO}

PSICOLOGIA ESCOLAR E EDUCACIONAL E INCLUSÃO 


\section{Juliana Mota Lima ${ }^{1}$; Larissa Mota Cerqueira ${ }^{2}$; Juliana Cristina Salvadori ${ }^{3}$.}

${ }^{1}$ Mestra em Educação e Diversidade - MPED; Universidade do Estado da Bahia - UNEB; Conceição do Coité, Bahia.

${ }^{2}$ Mestra em Educação e Diversidade - MPED; Universidade do Estado da Bahia - UNEB; Jacobina, Bahia.

${ }^{3}$ Doutora em Programa de Pós-graduação em Letras e Linguística pela Pontifícia Universidade Católica de Minas Gerais, Professora Titular da Universidade do Estado da Bahia.

\section{PALAVRAS-CHAVE: Psicologia Escolar. Inclusão Educacional. Psicologia Educacional.}

ÁREA TEMÁTICA: Psicologia Escolar e Educacional e Inclusão.

\section{INTRODUÇÃO}

A sociedade é organizada de forma que os indivíduos considerados desviantes geralmente são afastados de ambientes de socialização. Dentre os desafios para inclusão das pessoas com deficiência, Pimentel e Nascimento (2011) percebem a dificuldade de a sociedade lidar com as diferenças, ou seja, existem "modelos idealizados" como "normais", os quais correspondem a pessoas sem limitações sensoriais, físicas e mentais. Dessa forma, os indivíduos que estão fora desse padrão valorizado, geralmente sofrem discriminação e preconceito, atrelados aos estereótipos sociais. Além disso, evidenciam que a crença institucionalizada da inferioridade e incapacidade da pessoa com deficiência, contribui para que a exclusão das mesmas seja vista como algo 'natural'.

Moysés e Collares (2013) chamam a atenção para o conceito de normalidade caracterizado pela distinção entre normal e patológico, realizada de forma padronizada e classificatória. Verificase nos espaços escolares a busca e a valorização de avaliações e diagnósticos médico-psicológicos, porém é necessário destacar que as dificuldades relativas ao processo de escolarização dos "alunos problema" devem ser consideradas de maneira contextualizada (FREITAS e JUNIOR, 2014).

Ribeiro (2014) apresenta uma reflexão interessante sobre o processo de medicalização da educação, através da educação e psicologia escolar crítica, considerando que a lógica medicalizante ocorre quando questões sociais são tratadas como médicas ou biológicas, ou seja, a queixa escolar e os encaminhamentos dos estudantes são produzidos indicando a necessidade de profissionais da área da saúde para lidar com as mesmas. Nessa perspectiva emergem diagnósticos que normatizam e institucionalizam os sujeitos, a exemplo dos transtornos comportamentais e de aprendizagem tão frequentes no ambiente escolar.

De acordo com Ribeiro (2014) o número de diagnósticos relacionados a dificuldades de escolarização tem aumentado, sendo considerados como desviantes os alunos que não correspondem ao padrão de normalidade. Desse modo, a autora problematiza essa lógica que culpabiliza o estudante, ressaltando o papel da escola enquanto instituição responsável por acolher a diversidade e proporcionar 
estratégias que possibilitem o processo de ensino e aprendizagem de forma satisfatória.

Santos (2015) chama atenção para o discurso da homogeneização, predominante no ambiente escolar, evidenciando que a escola não está preparada para lidar com as diferenças, o que pode ser percebido tanto em aspectos físicos como simbólicos, relacionados a organização arquitetônica e práticas pedagógicas. Nesse sentido, percebe-se que a educação é para todos, porém a permanência dos "diferentes" não é garantida nesse espaço, ou seja, além de reproduzir o discurso da tolerância ao diferente, é necessária uma educação que respeite as diferenças.

Nessa perspectiva, este trabalho apresenta o objetivo de identificar os desafios enfrentados com os discentes que apresentam queixa escolar.

\section{METODOLOGIA}

A seguir, será apresentado um recorte da pesquisa qualitativa embasada no método estudo de caso e análise de conteúdo, realizada em Trabalho de Conclusão de Curso, na Pesquisa do Mestrado Profissional em Educação e Diversidade (MPED) entre os anos de 2018.2 a 2020.2.

\section{RESULTADOS E DISCUSSÕES}

Ao analisar os desafios vivenciados no contexto escolar em relação à educação de pessoas com deficiência, Matos e Mendes (2014) indicam a formação continuada de professores, a convivência com a diversidade e a relação família-escola como fatores primordiais para assegurar a acessibilidade para esses alunos. Nessa proposta inclusiva, demonstram a relevância da contribuição de outras áreas do conhecimento para dar conta desse processo, então indicam a possibilidade de a psicologia contribuir para compreensão do processo educativo, ressaltando a área de atuação da psicologia escolar para lidar com as demandas desse contexto referentes ao convívio e à aprendizagem na diversidade.

Verifica-se que o processo de inclusão educacional apresenta-se como um desafio, o que fica perceptível através das contribuições dos autores acima, ao dialogar sobre a produção das queixas escolares referentes aos considerados "alunos problemas", ou seja, os que não se encontram dentro dos critérios de normalidade valorizados socialmente, de modo que os mesmos tendem a ser encaminhados para avaliação médica e psicológica em busca de um diagnóstico, priorizando a concepção medicalizante. Vale ressaltar que a discussão crítica acerca dessa temática vem crescendo, o que fica evidente através dos questionamentos acerca do processo de medicalização e homogeneização, desconstruindo o discurso dominante, porém ainda necessita ser consolidada na realidade escolar, pois é necessário reconhecer a diversidade enquanto condição humana, e favorecer concepções que reconheçam e respeitem as diferenças no ambiente escolar com práticas pedagógicas que acolham e estimulem o desenvolvimento das potencialidades dos sujeitos. 
A discussão dos dados pautada na inclusão educacional contribuiu para problematizar as diferenças, considerando os preconceitos vivenciados pelos alunos que não se enquadram nos padrões de normatividade valorizados, o que foi destacado nas intervenções que aconteceram no ambiente escolar.

Os resultados dessa pesquisa apontam que ao serem questionados sobre a queixa escolar, indicando os desafios que indicam a necessidade de auxilio de outros profissionais, os colaboradores da educação sinalizaram: indisciplina/problemas de comportamento, dificuldade de aprendizagem e problemas familiares, o que corrobora com os dados apresentados na literatura referentes aos motivos frequentes de encaminhamentos. E ao falar sobre os desafios para lidar com a queixa escolar os profissionais da saúde e assistência social apontam a quantidade insuficiente de profissionais e o modelo biomédico, o que contribui para a discussão de acordo com a intersetorialidade, através da discussão histórica da valorização do modelo biomédico com ênfase na doença e da avaliação fragmentada do indivíduo.

Segundo Da Silva e Rodrigues (2014), é comum os professores sinalizarem que percebem a falta de motivação dos discentes, pela pouca participação nas aulas e atividades, o que corrobora com os resultados encontrados nessa pesquisa como desafios vivenciados pelos profissionais da educação. A ausência da participação familiar citada pelos colaboradores da pesquisa também é apontada por Souza (2006).

De acordo com Dazzani et al (2014) que tratam da temática queixa escolar, geralmente os encaminhamentos realizados pelos profissionais da educação sinalizam alunos com problemas de comportamento, dificuldade de aprendizagem e falta de participação familiar. Essa resposta também apareceu na fala dos entrevistados, corroborando os dados apresentados na literatura.

Souza (2013) sinaliza o sofrimento vivenciado por alunos que não se adequam aos critérios estabelecidos para atingir o sucesso no contexto educacional, os quais podem vivenciar experiências de exclusão e medicalização. Santos (2015), ressalta a valorização do viés clínico no espaço pedagógico, demonstrando que os medicamentos psicotrópicos são vistos como resposta necessária para lidar com as queixas escolares. Nessa perspectiva, Lessa (2013) analisa criticamente a questão do biopoder e da biopolítica envolvida no processo de medicalização escolar, evidenciando a necessidade de uma prática interdisciplinar entre Saúde-Educação, pois os fatores políticos pedagógicos não podem ser ignorados nesse processo. Nesse sentido, Correia (2016) demonstra a importância de um diálogo intersetorial entre saúde-educação, visando estratégias não medicalizantes para promoção da saúde escolar, através do engajamento dos setores envolvidos com uma compreensão integral do processo de escolarização.

Considerando os desafios vivenciados pelos profissionais da rede para lidar com a queixa escolar, é valido atentar para a discussão proposta por Lobo (2016) ao especificar que apenas realizar o encaminhamento não é suficiente para lidar com essas demandas. Nessa perspectiva, é valido destacar a potencialidade de fortalecer o diálogo intersetorial, educação, saúde e assistência social no município de Serrolândia, visando estratégias mais satisfatórias ao considerar os diversos fatores que interferem na queixa. 
Considerando os diversos fatores envolvidos na produção da queixa escolar, Camilo (2014) verifica a relevância da Intersetorialidade, ressaltando articulação e planejamentos estratégicos de profissionais distintos para colaborar com atendimento integral à queixa escolar, possibilitando uma corresponsabilidade dos profissionais em relação as demandas apresentadas pelos alunos. Correia (2016) também aponta a importância da política intersetorial Educação-Saúde, considerando a incidência dessas demandas nos serviços públicos, porém destaca a valorização do modelo médico que favorece o processo de medicalização para lidar com tais demandas. Dessa forma, Brambilla (2017) discute sobre a construção histórica que valoriza o saber médico, o que segundo Luengo (2010) contribui para manutenção da medicalização da aprendizagem. Nessa perspectiva, destaca-se o Programa Saúde na Escola (PSE), enquanto uma política intersetorial, o qual possibilita, segundo Graciliano et al., (2015), a participação da comunidade e desenvolvimento de ações de prevenção, promoção e atenção à saúde.

\section{CONCLUSÃO}

Essa pesquisa destaca-se pela proposta de aprofundamento de conhecimento sobre essa temática na região Nordeste, em Serrolândia, uma cidade do interior da Bahia, trazendo para discussão questões para serem refletidas e modificadas no cotidiano escolar. Nesse sentido, são colocados em pauta a valorização do modelo biomédico, os rótulos atribuídos aos alunos, a medicalização da educação, o que contribui para a cultura do fracasso escolar. Desse modo, verifica-se o potencial do fortalecimento da rede intersetorial (educação, saúde e assistência social) do município para lidar com essas demandas de queixas escolares.

Além disso, considerando que a maioria das pesquisas encontradas são realizadas na região Sudeste, a realização de uma pesquisa no Nordeste, demonstra a significância de acrescentar dados sobre o tema proposto nessa região, ressaltando a especificidade do lócus, além de contribuir para qualidade do ensino do município, facilitando a compreensão dos fatores que interferem na produção da queixa escolar e favorecendo maior inclusão e aceitação das diversidades nesse contexto.

\section{PRINCIPIAS REFERÊNCIAS}

MATOS, Selma Norberto; MENDES, Enicéia Gonçalves. A proposta de inclusão escolar no contexto nacional de implementação das políticas educacionais. Vitória da Conquista, $B A$, Práxis Educacional (online), v. 10, n. 16, p. 33-59, 2014.

MOYSÉS, Maria Aparecida Affonso.; COLLARES, Cecília A. L. Medicalização: o obscurantismo reinventado. Novas capturas, antigos diagnósticos na era dos transtornos. Campinas: Mercado de Letras, p. 41-64, 2013.

PIMENTEL, Susana Couto; NASCIMENTO, Lucinéia Jesus. Estudantes com deficiência na escola regular: estigmas e estereótipos construídos numa proposta de "inclusão". Feira de Santana, BA, SITIENTIBUS, n. 45, p. 11-25, jul/dez. 2011. 
SOUZA, Simone Vieira de. O estudante (in) visível na queixa escolar visível: um estudo sobre a constituição do sujeito na trajetória escolar. Tese (Doutorado em Educação) - Universidade Federal de Santa Catarina, 2013. 


\section{EDITORA}

OMNIS SCIENTIA
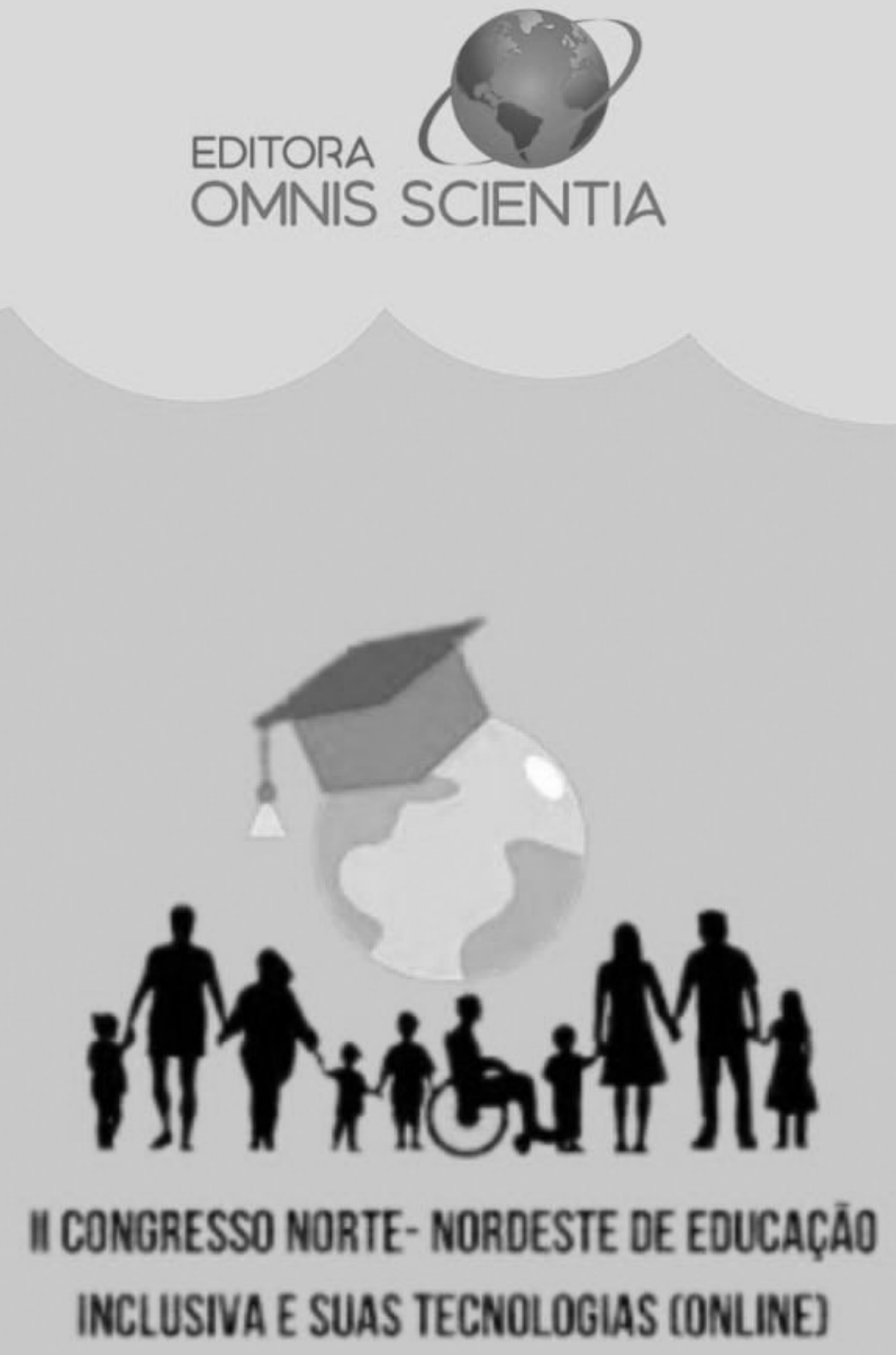

editoraomnisscientia@gmail.com $\square$ https://editoraomnisscientia.com.br/

@editora_omnis_scientia @ https://www.facebook.com/omnis.scientia.9 f +55 (87) 9656-3565@ 


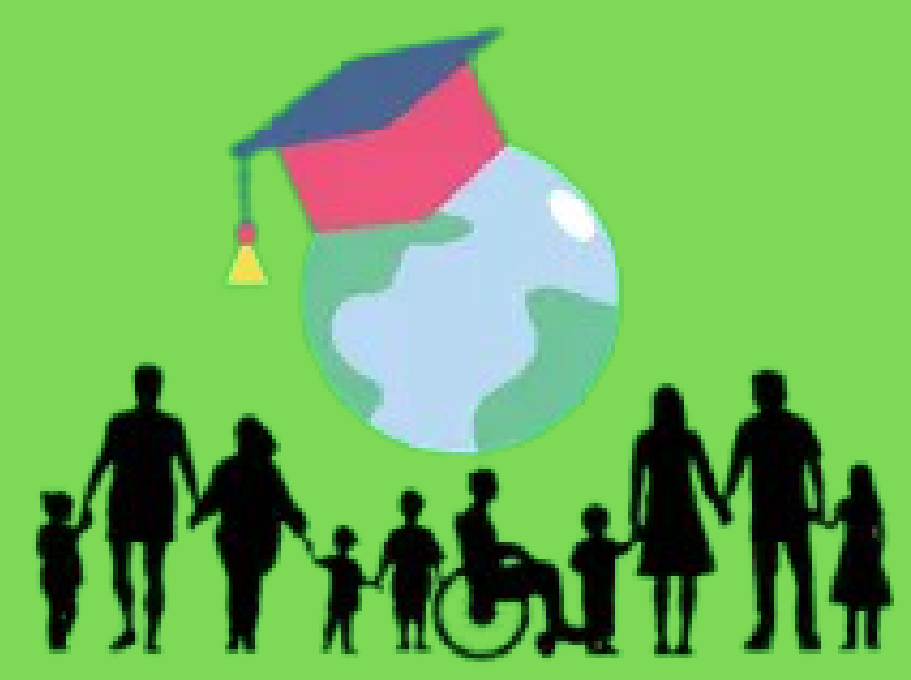

॥I CONGRESSO NORTE- NORDESTE DE EDUCAÇ̄̃O

INCLUSIVA E SUAS TECNOLOGIAS LONLINE]

\section{editoraomnisscientia@gmail.com $\square$ https://editoraomnisscientia.com.br/ \\ @editora_omnis_scientia [0]} https://www.facebook.com/omnis.scientia.9 f +55 (87) 9656-3565@ 